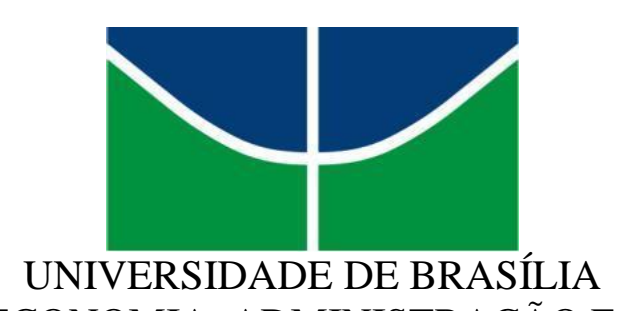

FACULDADE DE ECONOMIA, ADMINISTRAÇÃO E CONTABILIDADE PROGRAMA DE PÓS-GRADUAÇ̃̃̃O EM ADMINISTRAÇÃO MESTRADO PROFISSIONAL EM ADMINISTRAÇÃO PÚBLICA

ADRIANA ALVES XAVIER DURÃO

POLÍTICAS E PRÁTICAS DE GESTÃO DE PESSOAS E COMPROMETIMENTO ORGANIZACIONAL NO MINISTÉRIO DO MEIO AMBIENTE 
UNIVERSIDADE DE BRASÍLIA

FACULDADE DE ECONOMIA, ADMINISTRAÇÃO E CONTABILIDADE

PROGRAMA DE PÓS-GRADUAÇÃO EM ADMINISTRAÇÃO

MESTRADO PROFISSIONAL EM ADMINISTRAÇÃO PÚBLICA

ADRIANA ALVES XAVIER DURÃO

POLÍTICAS E PRÁTICAS DE GESTÃO DE PESSOAS E COMPROMETIMENTO ORGANIZACIONAL NO MINISTÉRIO DO MEIO AMBIENTE

Orientador: Prof. ${ }^{\circ}$ Dr. Antônio Isidro da Silva Filho

Dissertação de Mestrado 
UNIVERSIDADE DE BRASÍLIA

FACULDADE DE ECONOMIA, ADMINISTRAÇÃO E CONTABILIDADE

PROGRAMA DE PÓS-GRADUAÇÃO EM ADMINISTRAÇÃO

MESTRADO PROFISSIONAL EM ADMINISTRAÇÃO PÚBLICA

\author{
ADRIANA ALVES XAVIER DURÃO
}

\title{
POLÍTICAS E PRÁTICAS DE GESTÃO DE PESSOAS E COMPROMETIMENTO ORGANIZACIONAL NO MINISTÉRIO DO MEIO AMBIENTE
}

Dissertação apresentada ao Programa de PósGraduação em Administração da Universidade de Brasília, como requisito parcial à obtenção do título de Mestre em Administração - Mestrado Profissional em Administração. Área de Concentração: Administração Pública e Políticas Públicas Linha de Pesquisa: Organizações Públicas.

Composição da Banca Examinadora:

Prof. ${ }^{\circ}$ Dr. Antônio Isidro da Silva Filho, Universidade de Brasília Orientador

Prof. ${ }^{\circ}$ Dra. Gisela Demo, Universidade de Brasília Examinadora Interna

Prof. $^{\circ}$ Dr. Sandro Trescastro Bergue, Universidade de Caxias do Sul Examinador Externo

Prof. o Dr. Francisco Antônio Coelho Júnior, Universidade de Brasília Suplente

Brasília, em 18 de setembro de 2015. 
DEDICATÓRIA

Ao meu esposo, Lucas, que sempre me incentiva e me apoia em todos os meus projetos, pelos conselhos que me tornam uma pessoa melhor, e, principalmente, pelo amor que me alegra todos os dias.

A meus pais e irmãos, Jair, Luzia, Juliana, José Roberto e Marcos, que sempre compreenderam minha ausência e sempre estiveram ao meu lado, me ajudando e me amando.

À minha sogra e cunhados, Maria, Rafael, Silvana, Sônia, Jane e Sérgio, por todo amor e carinho que demonstram por mim.

Aos meus sobrinhos, Gustavo, Matheus, Douglas, Guilherme, Samuel e Diogo, por me fazerem esquecer as minhas preocupações e por sempre me receberem com um sorriso no rosto. 


\section{AGRADECIMENTOS}

Agradeço a Deus, por Ele sempre colocar pessoas tão especiais ao meu lado, sem as quais certamente não teria logrado êxito na minha pesquisa.

Ao meu orientador, Prof. Dr. Antônio Isidro da Silva Filho, excelente professor e orientador, pelo auxílio nas dúvidas que surgiram durante a realização deste trabalho, pelas sugestões de melhorias, sempre valiosas, e por me acalmar nos momentos de desespero. Agradeço também ao Víthor Rosa Franco, Assistente da Iniciação Científica da UnB, que conheci por intermédio do Prof. Isidro, pela grande ajuda na escolha do método, pelo ensinamento valioso na parte de estatística e por toda dedicação e paciência que teve comigo.

A Escola de Administração Fazendária (ESAF) e ao Programa de Pós-Graduação em Administração (PPGA/UnB), pela realização do curso e por todo apoio dos servidores da Secretaria do PPGA/UnB, em especial à Selma.

Aos professores do mestrado, por todo aprendizado durante o curso, bem como aos amigos do mestrado, que juntos vencemos todas as dificuldades, em especial ao meu amigo Andersson Pereira dos Santos que esteve ao meu lado nas inúmeras apresentações e trabalhos.

Ao Ministério do Meio Ambiente (MMA), que viabilizou financeiramente o meu mestrado e por ter sido lócus da minha pesquisa, em especial ao Coordenador Geral de Gestão de Pessoas, Ademar Paulo Gregório, por ter autorizado a realização da pesquisa e por toda ajuda na fase de coleta de dados, que juntamente com a Fernanda Ramalho e a Marcela Saad, da Assessoria de Comunicação Social (ASCOM), me auxiliaram na divulgação. Ao Jaime Heleno, da Coordenação Geral de Tecnologia da Informação e Informática (CGTI/SPOA), por disponibilizar os endereços de e-mails dos servidores.

Aos servidores do MMA por terem participado da pesquisa, em especial à Carolina Campos, Jadson Ferreira, Márcia Elias e Renata Tiemi pela ajuda na validação do questionário, e a todos os servidores da Coordenação Geral de Gestão de Pessoas, da Subsecretaria de Planejamento, Orçamento e Administração (CGGP/SPOA), que me apoiaram durante essa jornada.

A equipe da Divisão de Legislação de Pessoal (DILEP/CGGP/SPOA) pela amizade, carinho e todo apoio que recebi durante o meu mestrado, em especial ao Jadson Ferreira, meu substituto, que, por sua competência, permitiu que eu me ausentasse três meses para terminar a dissertação, sem sua ajuda não seria possível concretizar esse sonho.

Ao professor Henrique Pederiva pela orientação no início do mestrado, que por mais que tenham sido poucos encontros foram muito valiosos para mim. 
Aos professores Gisela Demo, Sandro Trescastro Bergue e Francisco Antônio Coelho Júnior por aceitarem prontamente compor minha banca examinadora e pelas valiosas considerações recebidas na qualificação do projeto.

Aos meus amigos que sempre estiveram dispostos a me ajudar e me descontrair quando eu precisava. 


\section{EPÍGRAFE}

“Aprender é a única coisa de que a mente nunca se cansa, nunca tem medo e nunca se arrepende." 


\section{RESUMO}

O presente estudo teve como objetivo verificar os efeitos de políticas e práticas da gestão de pessoas sobre o comprometimento organizacional de servidores do Ministério do Meio Ambiente (MMA). No referencial teórico, foram discutidos os conceitos e teorias sobre gestão de pessoas, incluindo suas políticas e práticas, além de estudar o construto comprometimento organizacional, abordando as bases e os focos do comprometimento, e, por fim, foram apresentados os resultados das principais pesquisas que estudaram conjuntamente os dois construtos. Quanto ao método, foram utilizadas a Escala de Políticas e Práticas de Recursos Humanos (EPPRH) e a Escala de Intenções Comportamentais do Comprometimento Organizacional (EICCO), e a análise de dados se deu por meio de estatística descritiva, ANOVA, teste t e da Modelagem por Equações Estruturais - MEE. A partir dos resultados foi possível inferir que os servidores do MMA não percebem as políticas e práticas de gestão de pessoas como adequadas, principalmente a de remuneração e recompensas, e não demonstraram ter intenção de um comportamento comprometido com a organização. Os resultados da ANOVA e do teste t demonstraram que os servidores lotados na Subsecretaria de Planejamento, Orçamento e Administração - SPOA/SECEX possuem uma percepção significativamente mais alta com relação à política de TD\&E do que os servidores lotados nas unidades finalísticas, àqueles servidores concordam com a política e práticas adotadas, já esses últimos discordam ou são indiferentes. Outra diferença significativa encontrada foi entre os servidores com idade de 21 a 30 anos e os que estão na faixa etária de 51 a 60 anos, os primeiros demonstraram ter intenções comportamentais de baixo comprometimento organizacional comparado aos últimos. Os servidores que ocupam cargo em comissão se mostraram indiferentes com as políticas de Envolvimento, TD\&E, Condições de Trabalho e Remuneração e Recompensas, já os que não ocupam cargo em comissão não concordam ou não percebem as referidas políticas. Por fim, o resultado da MEE demonstrou que as políticas de Recrutamento e Seleção, TD\&E e Condições de Trabalho são preditoras do comprometimento organizacional dos servidores do MMA, indicando que, quanto mais os servidores percebem as referidas políticas, maior será o comprometimento organizacional.

Palavras-chave: Políticas e Práticas de Gestão de Pessoas. Comprometimento Organizacional. Administração Pública. Modelagem por Equações Estruturais. 


\begin{abstract}
The main objective of this study was to verify the effects of policy and practice of human resources management (HRM) on organizational commitment of the Ministry of Environment (MMA) servants. In the theoretical framework, concepts and theories of HRM were discussed, including its policies and practices, as well as the organizational commitment construct, and finally, main researches and its results of the relations between HRM and organizational commitment were presented. In method, were used the Human Resource Management Policies and Practices Scale (HRMPPS), and the Scale of Behavioral Intentions of Organizational Commitment (EICCO). Data analysis was done using descriptive statistics, ANOVA, t-test and Structural Equation Modeling (SEM). The results showed that the MMA servants do not realize appropriate the policies and practices of HRM, especially the policies and practices of remuneration and rewards, and not showed behavioral intention to organizational commitment. The results of ANOVA and t-test showed that the servants crowded in SPOA/SECEX have a significantly higher perception regarding TD\&E policy than the crowded servants on purposive units, the former perceive the policy and practices adopted, and the latter disagree or are indifferent. Another significant difference was found between servants aged 21-30 years and those aged 51-60 years, the first presented low behavioral intentions regarding organizational commitment compared to last. The servants that occupy a commission office were indifferent to the TD\&E, working conditions and remuneration and rewards policies. Meanwhile, those who do not occupy a commission office not agree or do not realize these policies. Finally, the result of SEM has shown that policies of recruitment and selection, TD\&E and Working Conditions are predictors of organizational commitment of the MMA servants, indicating that the more servants realize such policies, the more it will be their organizational commitment.
\end{abstract}

Keywords: Human Resource Management Policies and Practices. Organizational Commitment. Public Administration. Structural Equation Modeling 


\section{SUMÁRIO}

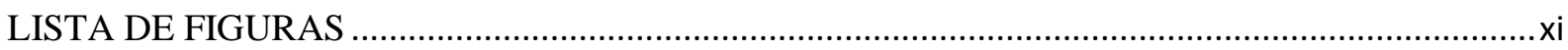

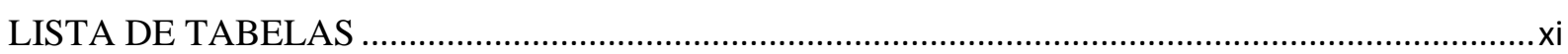

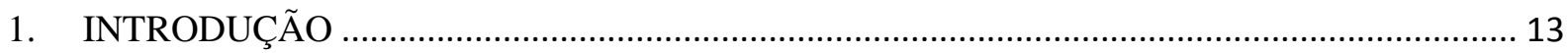

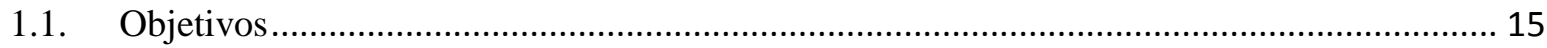

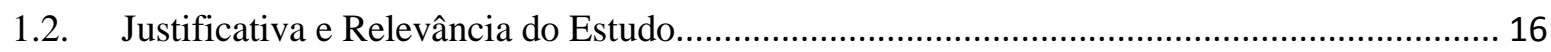

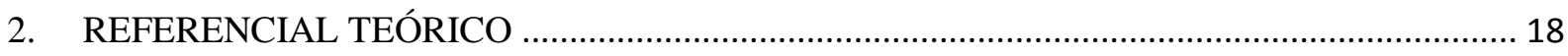

2.1 Políticas e Práticas de Gestão de Pessoas ............................................................................. 18

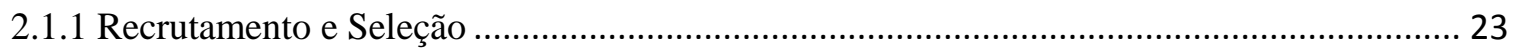

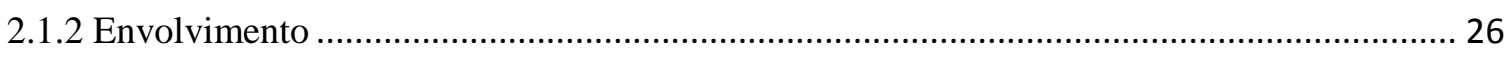

2.1.3 Treinamento, Desenvolvimento e Educação (TD\&E) ...................................................... 29

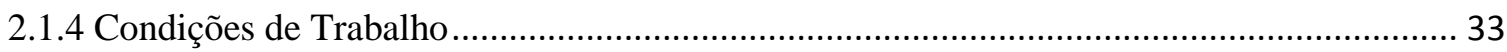

2.1.5 Avaliação de Desempenho e Competências............................................................................... 35

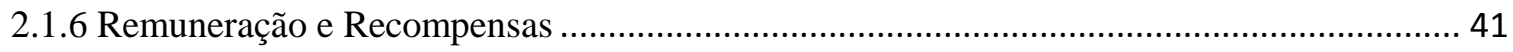

2.2 Comprometimento Organizacional ............................................................................. 45

2.2.1 As bases do comprometimento: afetiva, instrumental e normativa.............................. 46

2.2.2 Os focos do comprometimento: organização e carreira ............................................ 49

2.3 Relação entre Políticas e Práticas de Gestão de Pessoas e Comprometimento Organizacional.. 51

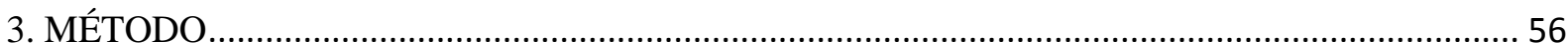

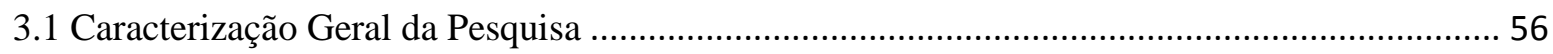

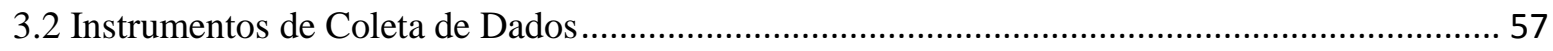

3.2.1 Descrição da Escala de Políticas e Práticas de Recursos Humanos (EPPRH) ...................... 57

3.2.2 Descrição da Escala de Intenções Comportamentais de Comprometimento Organizacional

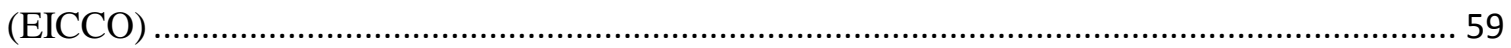

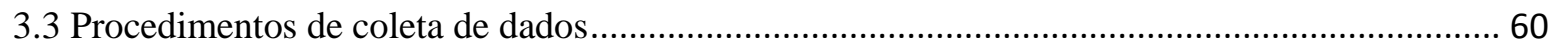

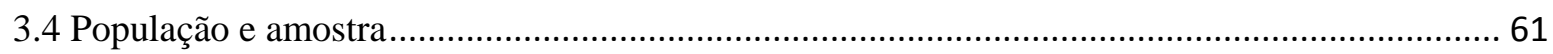

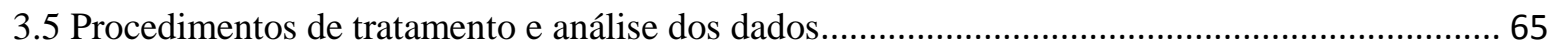

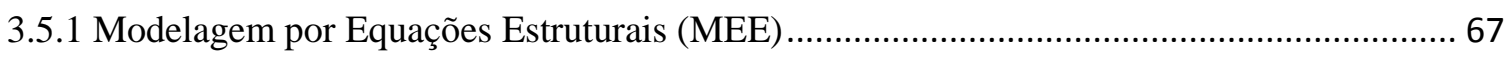




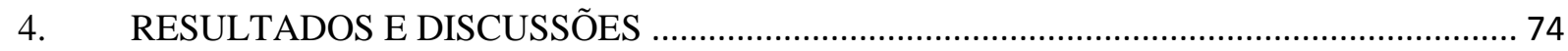

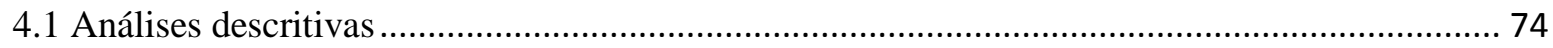

4.1.1 Percepção de Políticas e Práticas de Gestão de Pessoas............................................................ 74

4.1.2 Intenções Comportamentais de Comprometimento Organizacional ..................................... 78

4.2 ANOVA e Teste $t$ das diferenças entre as médias ............................................................. 80

4.3 Modelagem por Equações Estruturais para o relacionamento entre as variáveis .................. 91

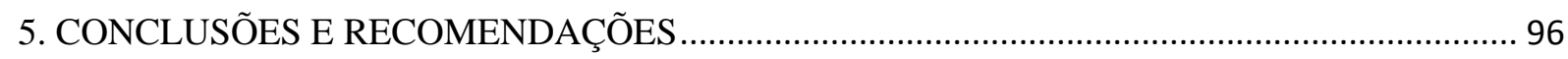

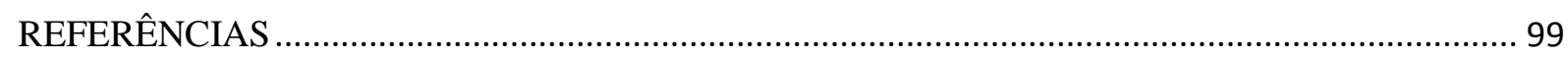

ANEXO A - Escala de Políticas e Práticas de Recursos Humanos (EPPRH) - versão original ......... 109

ANEXO B - Escala de Intenções Comportamentais de Comprometimento Organizacional (EICCO) -

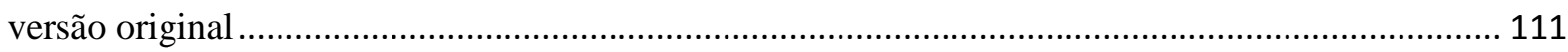

APÊNCICE A - Instrumento de Pesquisa: Questionário.............................................................. 116 


\section{LISTA DE FIGURAS}

Figura 1. Políticas de Gestão de Pessoas selecionadas para o estudo

Figura 2. Principais pontos abordados na literatura e definição operacional da política 24

Figura 3. Principais pontos abordados na literatura e definição operacional da política 27

Figura 4. Principais pontos abordados na literatura e definição operacional da política 30

Figura 5. Principais pontos abordados na literatura e definição operacional da política 34

Figura 6. Principais pontos abordados na literatura e definição operacional da política 36

Figura 7. Etapas da gestão de desempenho humano no trabalho 38

Figura 8. Principais pontos abordados na literatura e definição operacional da política 41

Figura 9. Conceitos das Formas de Remuneração 42

Figura 10. As dimensões do comprometimento com a carreira 51

Figura 11. Modelo teórico da pesquisa 54

Figura 12. Definição e composição dos fatores da EPPRH 58

Figura 13. Definições das facetas da EICCO 60

Figura 14. Distribuição de frequência da amostra por Carreira 63

Figura 15. Distribuição de frequência da amostra por tempo de serviço no MMA 64

Figura 16. Especificação do modelo de pesquisa - MEE 68

Figura 17. Definição dos índices de ajuste do modelo utilizados na pesquisa 72

Figura 18. Resultados da MEE. 94

\section{LISTA DE TABELAS}

Tabela 1. Resultados da Regressão Hierárquica (políticas de gestão de pessoas e comprometimento organizacional).

Tabela 2. Quantitativo de servidores do MMA, por situação funcional e gênero 61

Tabela 3. Caracterização da amostra por variáveis sociodemográficas 62

Tabela 4. Distribuição de frequência dos demais dados profissionais 64

Tabela 5. Resultados da análise de confiabilidade das escalas 66

Tabela 6. Estatística descritiva dos itens da EPPRH por fatores. 75 
Tabela 7. Estatística descritiva da EICCO

Tabela 8. ANOVA da variável idade com os fatores da EPPRH.

Tabela 9. Resultado do teste Post Hoc/Tukey - EPPRH/Idade. 82

Tabela 10. ANOVA da variável unidade de lotação com os fatores da EPPRH... 82

Tabela 11. Resultado do teste Post Hoc/Tukey - EPPRH/Unidade de Lotação 83

Tabela 12. Resultado do teste Post Hoc/Tukey - EPPRH/Unidade de Lotação - após alteração 85

Tabela 13. ANOVA da variável tempo de serviço no órgão com os fatores da EPPRH 86

Tabela 14. Resultado do teste Post Hoc/Tukey - EPPRH/Tempo de serviço no órgão 87

Tabela 15. Resultado do teste Post Hoc/Tukey - EPPRH/Tempo de serviço no órgão - após alteração88 Tabela 16. ANOVA da variável idade com o fator da EICCO 88

Tabela 17. Resultado do teste Post Hoc/Tukey - EICCO/Idade . 89

Tabela 18. Teste t da variável ocupação de cargo em comissão com os fatores da EPPRH 89

Tabela 19. Teste t da variável ocupação de cargo em comissão com o fator da EICCO 90

Tabela 20. Cargas fatoriais da EPPRH. 91

Tabela 21. Cargas Fatoriais da EICCO 92

Tabela 22. Resultados dos índices de ajuste do modelo. 93

Tabela 23. Matriz de covariância dos fatores da EPPRH. 95 


\section{INTRODUÇÃO}

A pesquisa de Albuquerque (1999), que buscou identificar quais seriam as grandes tendências de mudanças na Gestão de Pessoas e nas relações de trabalho que possibilitariam as organizações alcançar seus objetivos, concluiu que as organizações deveriam assumir como premissas a valorização do capital humano e a atração e a manutenção de indivíduos com alto potencial. Além disso, é essencial a criação de condições favoráveis à motivação dos empregados ou servidores e à integração dos grupos, no intuito de atingir metas organizacionais, possibilidades de crescimento funcional e desenvolvimento profissional na própria instituição, bem como o oferecimento de incentivos vinculados a resultados e adaptação das políticas de gestão de pessoas à realidade da organização e ao contexto externo.

Na administração pública brasileira, o Decreto Lei no 200 (1967), ao dispor sobre as normas gerais do pessoal civil, previu a necessidade de revisão da legislação e das normas referentes ao pessoal do Serviço Público Civil, com objetivo de adequá-las a alguns princípios, dos quais se destacam os seguintes: valorização do servidor e dignificação da função pública; aumento da produtividade; profissionalização e aperfeiçoamento do servidor público; fortalecimento do sistema de mérito para ingresso na função pública e para indicação de ocupantes de cargos comissionados, de livre nomeação e exoneração; e constituição de quadros de dirigentes mediante formação e aperfeiçoamento de administradores capacitados a garantir a qualidade, produtividade e continuidade da ação governamental.

A investidura em cargo ou emprego público no Brasil ocorre por intermédio de prévia aprovação em concurso público, nos termos do art. 37, inciso II, da Constituição Federal (1988), ressalvadas as nomeações para cargo em comissão, que são de livre nomeação e exoneração. Diante desse preceito constitucional, subentende-se que os candidatos aprovados em concurso público, dentro do número de vagas, são os agentes mais qualificados e bem preparados para exercer determinado cargo ou emprego público, uma vez que se mostraram os mais aptos no certame.

De acordo com Amaral (2006), o modelo de federalismo do Brasil enseja autonomia dos critérios de definição da organização do setor público, que convive com disparidades de direitos, remuneração e requisitos para exercer a função pública, ainda que todos os agentes sejam regidos pela mesma Constituição Federal. Além disso, há gestores públicos sem a percepção de que o conhecimento dos servidores representa papel estratégico para o sucesso das políticas públicas. No entanto, existem iniciativas, no sentido de formar burocracias profissionalizadas, no serviço público brasileiro, mediante a retomada dos concursos públicos 
regulares e políticas de capacitação que motivem os servidores a prestarem serviços de boa qualidade (Amaral, 2006).

Nesse sentido, o Decreto $\mathrm{n}^{\mathrm{o}} 5.707$ (2006) instituiu a Política Nacional de Desenvolvimento de Pessoal (PNDP), no âmbito da administração pública federal direta, autárquica e fundacional, destacando-se, dentre suas finalidades, o desenvolvimento permanente do servidor e a adequação das competências requeridas dos servidores aos objetivos das instituições. No Decreto, conceitua-se gestão por competência como a gestão da capacitação orientada para o desenvolvimento do conjunto de conhecimentos, habilidades e atitudes necessárias ao desempenho das funções dos servidores, visando ao alcance dos objetivos da instituição.

Dessa forma, a partir do ingresso no serviço público, os servidores necessitam de constante capacitação e desenvolvimento, para que possam desenvolver conhecimentos, habilidades e atitudes para o desempenho das atribuições do cargo. Todo esse processo, de capacitação e desenvolvimento constante dos servidores, exige investimentos de recursos, inclusive financeiros, por parte da Administração.

O Ministério do Meio Ambiente (MMA), local de atividade profissional da autora da presente pesquisa, em virtude da necessidade de aprimoramento das políticas de gestão de pessoas, implantou, no final do exercício de 2011, programas que incentivam a aprendizagem constante dos servidores, por meio de apoio financeiro, na forma de subsídios, para a realização de cursos de graduação, pós-graduação e línguas estrangeiras, e, ainda, o incentivo constante à capacitação, por meio da oferta de cursos de turmas abertas e fechadas, contemplados no Plano Anual de Capacitação (PAC).

Em 31 de dezembro de 2013, foi publicada a Lei $n^{\circ} 12.778$ (2013), que criou a Gratificação de Qualificação (GQ) para a Carreira de Especialista em Meio Ambiente CEMA e para o Plano Especial de Cargos do Ministério do Meio Ambiente e do Instituto Brasileiro do Meio Ambiente e dos Recursos Naturais Renováveis - IBAMA (PECMA). A referida gratificação é devida aos servidores titulares de cargos de provimento efetivo de nível superior e intermediário do MMA, em retribuição à formação acadêmica e profissional, obtida mediante participação, com aproveitamento, em cursos regularmente instituídos de pósgraduação lato ou stricto sensu, graduação, capacitação ou qualificação profissional.

Outra medida que fortaleceu o investimento do MMA na política de capacitação e desenvolvimento foi a regulamentação dos critérios e procedimentos para promoção dos servidores pertencentes à Carreira de Especialista em Meio Ambiente (CEMA). No Decreto $\mathrm{n}^{\circ} 8.423$ (2015), ficou prevista a necessidade de comprovação de participação em eventos de 
capacitação com conteúdo e carga horária mínima definidos, para que se efetive a promoção do servidor. O requisito de horas-aula é diferenciado para cada tipo de promoção.

O Tribunal de Contas da União (TCU) realizou, em maio de 2013, levantamento em algumas organizações públicas, incluindo o MMA, com o intuito de conhecer e avaliar a situação da governança e da gestão de pessoas na Administração Pública Federal. No relatório individual da avaliação, o TCU apresenta o índice de governança de pessoas - iGovPessoas do MMA, que foi de 55,1\%, classificado como intermediário, e estando acima da média dos demais ministérios avaliados (41,8\%), e da média da administração pública federal (40,2\%).

Dessa forma, conforme mencionado por Ventura (2012), a gestão de pessoas adota regras de governança em que a realização dos propósitos organizacionais, detalhados na visão, missão, objetivos e metas organizacionais, ou seja, no planejamento estratégico da organização, passa pelo empregado, ou no caso da administração pública, pelo servidor público. Essa formatação da gestão de pessoas requer o compartilhamento dos propósitos organizacionais. No entanto, isso implica no complexo processo da busca de alinhamento e compartilhamento dos interesses dos indivíduos e das organizações.

E é com esse desafio, de tentar alinhar e compartilhar os interesses dos indivíduos e das organizações, que se estudam, conjuntamente, dois construtos: políticas e práticas de gestão de pessoas e comprometimento organizacional. Na visão de Legge (1995), políticas e práticas adequadas de gestão de pessoas devem promover o comprometimento dos empregados ou, no caso estudado, dos servidores públicos, e, como consequência, o empregado terá boa vontade em agir de maneira flexível e adaptativa. Demo, Fogaça, Nunes, Edrei e Francischeto (2011), ao realizarem uma revisão da produção nacional sobre políticas de gestão de pessoas, no período de 2000 a 2010, identificaram a necessidade de se estudar as relações entre políticas e práticas de gestão de pessoas e outras variáveis do comportamento organizacional.

Diante do exposto, o presente estudo propõe responder a seguinte pergunta de pesquisa: quais os efeitos políticas e práticas de gestão de pessoas exercem sobre o comprometimento organizacional de servidores do Ministério do Meio Ambiente (MMA)? A partir dessa pergunta, foram elaborados os objetivos gerais e específicos desta pesquisa.

\subsection{Objetivos}

O objetivo geral do presente estudo é verificar os efeitos de políticas e práticas de gestão de pessoas sobre o comprometimento organizacional de servidores do Ministério do Meio Ambiente (MMA). 
Para o alcance do objetivo geral proposto foram traçados os seguintes objetivos específicos:

i. Identificar a percepção dos servidores acerca das políticas e práticas de gestão de pessoas do MMA;

ii. Identificar a intenção comportamental dos servidores do MMA em relação ao comprometimento organizacional; e

iii. Verificar a influência dos dados sociodemográficos e profissionais nos dois construtos estudados (políticas e práticas de gestão de pessoas e comprometimento organizacional).

\subsection{Justificativa e Relevância do Estudo}

Diversos autores compartilham a ideia de que a organização é composta por indivíduos e grupos, e possui um plano consciente e explícito, indicando sua finalidade, ou seja, sua razão de ser. Geralmente, tal plano é representado por planejamento com objetivos e estruturas organizacionais formais. Há também planos informais, não conscientes nem planejados, compostos por vínculos pessoais, conflitos, temores, relações interpessoais, idealizações, desejos de poder, sentimentos de inveja, de vaidade e de identificação (Kramer \& Faria, 2007).

Kramer e Faria (2007) enfatizam que o fato de indivíduos estabelecerem vínculos com as organizações em que atuam não garante que os objetivos corporativos serão atingidos. Persiste, porém, a expectativa de compromissos com resultados organizacionais e desempenhos coletivos esperados e alcançados, pois os indivíduos participam e integram organizações sociais.

Nesse sentido, para Leite e Albuquerque (2011), a gestão de pessoas em organizações tem despertado interesse recorrente dos pesquisadores contemporâneos, em virtude da crescente descoberta da necessidade de valorização do capital humano como fonte de valor e de competitividade organizacional.

O presente estudo encontra justificativa em lacunas de pesquisas sobre comprometimento organizacional. Medeiros, Albuquerque, Siqueira e Marques (2003), ao delinearem o estado da arte da pesquisa sobre comprometimento organizacional, no Brasil, identificaram a necessidade de abordagem das várias dimensões desse fenômeno. Para eles, é necessário desenvolver novas formas de mensuração do comprometimento, uma vez que as pesquisas tem se prendido à utilização de questionários aplicados no formato Likert. Os 
autores sugerem, ainda, pesquisas que possam identificar se sistemas de recursos humanos, formados por amplo conjunto de práticas e políticas, produzem comprometimento.

A escolha do MMA para realização da pesquisa se deu em virtude de dois aspectos: i) facilidade de acesso aos servidores e aos dados da organização, em face do vínculo existente entre a organização e a pesquisadora; e ii) peculiaridade do contexto organizacional, por se tratar de um órgão público e pelo fato de que não foram encontrados estudos que relacionem políticas de gestão de pessoas e comprometimento organizacional em órgãos da administração direta federal.

Dessa forma, com os resultados da pesquisa, será possível identificar os efeitos de políticas e práticas da gestão de pessoas sobre o comprometimento organizacional dos servidores do MMA, o que poderá propiciar, como contribuição no campo profissional, uma revisão das políticas e práticas de gestão de pessoas com objetivo de aperfeiçoamento da gestão. Além disso, o órgão terá a oportunidade de entender como os servidores percebem as políticas de gestão de pessoas e como se avaliam com relação ao comprometimento organizacional.

A contribuição acadêmica será no sentido de aplicar duas escalas recém revisadas e validadas (Escala de Políticas e Práticas de Recursos Humanos e a Escala de Intenções Comportamentais de Comprometimento Organizacional), utilizando o método de modelagem por equações estruturais para análise dos dados, e, consequentemente, avaliar os possíveis limites das medidas desenvolvidas, em face do contexto organizacional estudado, tendo em vista que não foram encontradas outras pesquisas, utilizando concomitantemente as duas escalas, nos setores público ou privado.

A estrutura sequencial deste estudo, a partir da presente introdução, corresponde a: apresentação da literatura sobre os dois construtos (políticas e práticas de gestão de pessoas e comprometimento organizacional) no referencial teórico, descrição do método de pesquisa, detalhamento dos resultados e discussões, e, por fim, as conclusões e recomendações. 


\section{REFERENCIAL TEÓRICO}

Nesta seção, será tratado, inicialmente, o papel estratégico da gestão de pessoas nas organizações, em seguida, serão identificadas as políticas e práticas de gestão de pessoas selecionadas para o presente estudo e apresentadas as respectivas definições teóricas. Logo após, será apresentada a construção teórica do construto comprometimento organizacional, descrevendo as principais bases (afetiva, instrumental e normativa) e os focos do comprometimento (organização e carreira). Por fim, com intuito de subsidiar a discussão dos resultados da presente pesquisa, serão apresentadas as principais pesquisas que tiveram como objetivo relacionar as polícias e práticas de gestão de pessoas e o comprometimento organizacional.

\subsection{Políticas e Práticas de Gestão de Pessoas}

As pesquisas na área de gestão de pessoas - ou recursos humanos, como também é denominada - têm seguido quatro abordagens predominantes e complementares: comportamental, estratégica, de recursos da firma e sistêmica (Lacombe \& Chu, 2008). Na presente pesquisa, serão tratadas as abordagens comportamental e estratégica.

De acordo com Lacombe e Chu (2008), a abordagem comportamental enfatiza os papéis necessários à implementação da estratégia, com o fundamento de que o comportamento é o principal mediador entre estratégia e implementação efetiva e de que políticas e práticas de gestão de pessoas devem ser voltadas para a promoção e o controle dos comportamentos necessários à implementação. Acredita-se que diferentes estratégias necessitam de diferentes comportamentos dos indivíduos.

Os estudos realizados pela Escola das Relações Humanas identificaram a importância dos fatores psicológicos no desempenho dos funcionários. Com os estudos comportamentais, foi possível perceber a influência das ações da organização na motivação dos indivíduos. Descobriu-se que a motivação não se caracteriza apenas por recompensas monetárias, mas também por propostas de trabalho e perspectivas de carreira, desafios e responsabilidades que a organização oferece. Dadas tais propostas e perspectivas, os indivíduos permaneceriam no trabalho e comungariam objetivos organizacionais com objetivos pessoais (Ventura, 2012).

Nesse sentido, Chew (2004) identificou dois conjuntos de fatores que favorecem a prática de retenção dos profissionais de organizações australianas: i) fatores de gestão de pessoas (ajustes entre pessoas e organizações, remuneração, reconhecimento e recompensa, treinamento e desenvolvimento de carreira, e oportunidades desafiadoras de trabalho); e ii) 
fatores organizacionais (atitude dos líderes, políticas e cultura da organização, relacionamento interpessoal, e ambiente de trabalho satisfatório).

A abordagem estratégica da gestão de pessoas caracteriza-se pelo foco na identificação das demandas da organização e dos funcionários, considerando uma perspectiva de curto e de longo prazo, e na transformação dessas demandas em um modelo de gestão de pessoas capaz de conduzir a implementação da estratégia organizacional e levar a uma maior integração das capacidades da organização, desenvolvendo um novo relacionamento entre organização e funcionário. Essa abordagem da gestão de pessoas irá converter a estratégia em ação e buscar um alinhamento das políticas de gestão de pessoas ao desempenho da organização e dos funcionários. Dessa forma, para ser estratégica, a gestão de pessoas necessita contemplar estratégia, estrutura, pessoas e processos em suas ações (Höpner, Garay, Santos, Silva, Medeiros \& Flach, 2008).

Com o advento da sociedade do conhecimento, as organizações tem voltado sua atenção para as pessoas e a sua capacidade contínua de contribuição para a geração de valor para as organizações. Nesse sentido, a área de gestão de pessoas não deve, mesmo adotando a abordagem estratégica, deixar de exercer uma de suas atribuições mais valiosas, que é a de gerir de forma integrada e participativa a contribuição dos funcionários. Isso implica uma gestão de pessoas capaz de reconhecer, se envolver e atender as demandas, preocupações, anseios e necessidades dos funcionários, bem como prover meios e condições para que as pessoas possam dar sua máxima contribuição para o sucesso da organização (Ulrich, 1998).

Outra importante atribuição da gestão estratégica de pessoas consiste em atuar no sentido de uma liderança transformacional, atentando para auto-eficácia, coesão do grupo, comprometimento e performance dos membros da organização, certificação das necessidades e planos, provisão de recursos, desenvolvimento de suporte interno e externo para a mudança e para superação de resistências, manutenção do comprometimento, análise do gap existente entre a performance e estratégia para o futuro, e a adaptação dos membros com relação às inovações. Além disso, é importante atentar-se com o desenvolvimento e educação continuada dos colaboradores, tornando os processos de aprendizagem e mudanças eficientes (Höpner et al., 2008).

A versão mais atual da gestão de pessoas entende o colaborador como fator estratégico da organização, sendo fundamental nos processos de pactuação e atingimento de metas e tomada de decisões em busca de maior efetividade e competitividade organizacionais (Demo, Nunes, Fogaça, Barcelos \& Roure, 2012). Nesse sentido, Horta, Demo \& Roure (2012) acrescentam que: 
No momento em que fontes tradicionais de vantagem competitiva, como tecnologia, não são mais consideradas suficientes para garantir uma posição competitiva sustentável, as pessoas passam a ser competências essenciais de diferenciação estratégica.

No campo da administração pública, segundo Pacheco (2010), desde os anos 1970, as sociedades passaram a demonstrar um conjunto de pressões e questionamentos sobre a maneira de organização e funcionamento do Estado que havia prevalecido durante o século XX. Essas pressões e questionamentos tinham origem em fenômenos econômicos (pressão fiscal, fim do crédito internacional barato, competição em escala global), sociais (mudança dos padrões demográficos e no perfil familiar, novos problemas complexos como violência, drogas, Aids, migrações), tecnológicos (novas tecnologias de informação e comunicação, novas aplicações em saúde e consequente aumento do gasto público, opinião pública mais informada e exigente) e políticos (questionamentos da política tradicional, proliferação dos grupos de causa única, anseios de aprofundamento da democracia, perda de legitimidade dos governos e da burocracia). Todas essas pressões sobre o Estado questionavam o paradigma da burocracia.

O modelo de administração burocrático predominou nas democracias ocidentais durante maior parte do século XX. A Administração Pública seguia os princípios da teoria da burocracia de Max Weber que se caracteriza pela divisão vertical do trabalho, a distribuição da autoridade na estrutura hierárquica, a definição de regras formais de funcionamento e a concentração de responsabilidade pelas ações no topo da organização (Araújo, 2013).

A crise da administração pública burocrática iniciou ainda no regime militar não apenas porque não foi capaz de eliminar o patrimonialismo que sempre a vitimou, mas também porque esse regime, ao invés de consolidar uma burocracia profissional no país, por meio da redefinição das carreiras e de um processo sistemático de abertura de concursos públicos para a alta administração, preferiu o caminho mais curto do recrutamento de administradores por meio das empresas estatais (Bresser-Pereira, 1996).

As disfunções do modelo burocrático, como a capacidade limitada de resposta e adaptação aos problemas, a falta de iniciativa, a desresponsabilização, o excesso de formalismo e de encargos financeiros com o funcionamento da Administração Pública, foram algumas das razões para a mudança. Assim, iniciou-se um processo de procura de formas alternativas de fornecimento de serviços públicos, em virtude da necessidade dos políticos possuírem mais informação e maior controle sobre o funcionamento e os custos dos serviços públicos (Araújo, 2013). 
De acordo com Araújo (2013), a influência das ideias de economistas neoliberais e da literatura da gestão do setor privado foram determinantes para a reconfiguração da estrutura e funcionamento da Administração Pública. A nova gestão pública então surge como resposta aos problemas emergentes da Administração, de modo que fossem preservados os seus valores e princípios.

Novamente a influência da gestão privada contribuiu para a importação de técnicas de gestão daquele setor para o setor público, com objetivo de introduzir a eficiência na Administração Pública, como, por exemplo, a utilização de tecnologias mais sofisticadas, maior disciplina para a produtividade, a implementação da gestão profissional e a criação de condições para os gestores terem maior liberdade em suas atividades (Araújo, 2013).

A reforma iniciada pelo Decreto-Lei 200/1967 foi uma tentativa de superação da rigidez burocrática, podendo ser considerada como um primeiro momento da administração gerencial no Brasil. Toda a ênfase foi dada à descentralização mediante a autonomia da administração indireta, a partir do pressuposto da rigidez da administração direta e da maior eficiência da administração descentralizada (Bresser-Pereira, 1996).

Nesse diapasão, fatores como mudanças tecnológicas, globalização da economia e diversidade da força de trabalho influenciam significativamente a gestão das organizações. Além desses fatores, existem outros mais específicos, para o setor público, como diversificação de demandas democráticas, capacidade de entregas administrativas com qualidade e no tempo determinado, e controle social sobre as escolhas realizadas por agentes públicos não eleitos. Esses fatores exigem capacidade organizacional de selecionar, reter e desenvolver profissionais aptos a se adaptar às mudanças do meio que atuam (Leite \& Albuquerque, 2013). Nesse sentido, a gestão estratégica de pessoas assume ser possível identificar e desenvolver comportamentos necessários à implementação da estratégia organizacional, utilizando-se, para isso, as políticas e práticas de pessoal (Lacombe \& Chu, 2008).

As políticas e práticas de gestão de pessoas assumem papel especial no desenvolvimento, na valorização e na retenção dos talentos, e devem possibilitar a formação de organizações que sejam capazes de executar estratégias, ser mais eficientes, envolver os funcionários e gerenciar as mudanças (Demo, 2008). Na visão de Demo (2010), as políticas e práticas de gestão de pessoas precisam favorecer um maior bem-estar das pessoas, permitindo-lhes uma maior realização pessoal e profissional. Legge (1995) complementa que as políticas de gestão de pessoas devem ser integradas ao planejamento estratégico da organização e utilizadas para reforçar a cultura organizacional. 
Para Loiola, Bastos e Teixeira (2003), as práticas que compõem o domínio da gestão de pessoas são aquelas que envolvem uma combinação de organização do trabalho e políticas de administração de recursos humanos, como: recompensas crescentes pela dedicação, compartilhamento de ideias, aumento do bem-estar do trabalhador, remuneração por desempenho, metas mais desafiadoras, equipes autogeridas, trabalho em equipe, treinamento e desenvolvimento, dentre outras. Essas práticas são adotadas com objetivo de oferecer maior participação na tomada de decisão, oportunidades para aprender novas habilidades e um incremento nos incentivos financeiros para que seja estimulada a dedicação e os esforços dos colaboradores para o alcance das metas estabelecidas.

Dessa forma, Demo, Nunes, Fogaça, Barcelos e Roure (2012) entendem como necessários a modificação e o aprimoramento das políticas de gestão de pessoas para se ajustarem à estratégia organizacional e, ainda, para que possam, efetivamente, valorizar os colaboradores. Katou (2012) evidenciou que as políticas de gestão de pessoas possuem um efeito positivo sobre o desempenho organizacional, o qual é avaliado por meio de atitudes (satisfação, comprometimento, motivação) e comportamentos (faltas, disputas) dos colaboradores.

Para Silva, Balassiano e Silva (2014), algumas práticas laborais tem contribuído para a renovação da gestão de pessoas no setor público, e podem ser reconhecidas como iniciativas que pretendem dar uma visão estratégica para a gestão de pessoas no serviço público. São exemplos dessas práticas, o maior incentivo que se tem dado à capacitação e ao desenvolvimento dos servidores e os critérios formais para a revisão da remuneração e da avaliação de desempenho.

No presente trabalho, em virtude da grande variedade de políticas de gestão de pessoas encontradas na literatura, serão adotadas as políticas definidas por Demo, Fogaça, Nunes, Edrei e Francischeto (2011). Na referida pesquisa, os autores tomaram por base o estudo de Demo (2008), ao construir a Escala de Percepção de Políticas de Gestão de Pessoas (EPPGP), e ainda o resultado da revisão bibliográfica realizada com base em sínteses da produção internacional sobre o tema e dos estudos empíricos publicados em nível nacional nos periódicos de Administração, no período de 2000 a 2010. A figura abaixo apresenta as políticas de gestão de pessoas selecionadas para o estudo: 


\begin{tabular}{|l|}
\hline \multicolumn{1}{|c|}{ Políticas } \\
\hline 1. Recrutamento e Seleção \\
\hline 2. Envolvimento \\
\hline 3. Treinamento, Desenvolvimento e Educação - TD\&E \\
\hline 4. Condições de Trabalho \\
\hline 5. Avaliação de Desempenho e Competências \\
\hline 6. Remuneração e Recompensas \\
\hline
\end{tabular}

Figura 1. Políticas de Gestão de Pessoas selecionadas para o estudo

Fonte: elaborado pela autora a partir de Demo et al.(2011)

Demo et al. (2011) adotam o termo "política" como definição constitutiva, ou seja, quando os conceitos são definidos em termos de dicionários e teorias, e o termo "práticas" como definição operacional, sendo o mais abrangente possível da variável, ou seja, a variável deve ser definida em termos de operações concretas e comportamentos físicos por meio dos quais se expressa e se traduz .

A seguir, serão apresentadas as definiçõoes e características das políticas e práticas de gestão de pessoas selecionadas no presente estudo de acordo com a visão de Demo et al. (2011) e outros autores, incluindo algumas políticas e práticas adotadas na administração pública federal.

\subsubsection{Recrutamento e Seleção}

Para Demo et al. (2011) a política de Recrutamento e Seleção trata-se de proposta articulada da organização, com construções teóricas e práticas, para atrair colaboradores, estimulá-los a se candidatar e selecioná-los, buscando harmonizar valores, interesses, expectativas e competências das pessoas com as características e demandas do cargo e da organização. Os autores selecionaram os principais pontos abordados na literatura sobre o tema e apresentaram a definição operacional da política de recrutamento e seleção, conforme Figura 2: 


\begin{tabular}{|c|c|c|}
\hline Politica & Autores & Principais pontos abordados na literatura \\
\hline $\begin{array}{l}\text { Recrutamento } \\
\text { e Seleção }\end{array}$ & $\begin{array}{l}\text { Dessler (2002), } \\
\text { Mathis e Jackson (2003), } \\
\text { Orlitzky (2007), } \\
\text { Schmitt e Kim (2007), } \\
\text { Armstrong (2009), } \\
\text { Bohlander e Snell (2009), e } \\
\text { Lievens e Chapman (2010). }\end{array}$ & $\begin{array}{l}\text { Recrutamento: práticas e atividades tomadas pela organização com o } \\
\text { objetivo principal de identificar e atrair potenciais colaboradores. } \\
\text { Seleção: processo de escolher pessoas qualificadas para preencher os } \\
\text { cargos vagos da organização. } \\
\text { Atividades estratégicas para a organização. } \\
\text { Devem estar alinhadas às outras politicas. } \\
\text { Informações a respeito de etapas, critérios, desempenho e resultados } \\
\text { do processo seletivo devem ser divulgadas aos candidatos. } \\
\text { Utilização de vários instrumentos de seleção. } \\
\text { Testes devem ser desenvolvidos e validados pelas organizações. } \\
\text { Testes de seleção conduzidos por pessoas capacitadas, imparciais e } \\
\text { capazes de verificar as reais percepções das funções relacionadas ao } \\
\text { trabalho (lacunas a serem preenchidas) e das características } \\
\text { organizacionais determinantes ao processo. } \\
\text { Os processos seletivos devem ser elaborados a fim de atrair candidatos } \\
\text { competentes e profissionais qualificados. } \\
\text { Imagem organizacional influencia o recrutamento e a seleção e deve } \\
\text { ser favorável para a atração dos profissionais desejados. }\end{array}$ \\
\hline \multicolumn{3}{|c|}{$\begin{array}{l}\text { Definição operacional: recrutamento intemo (lançamento de cargo, registros de pessoal, bancos de habilidades, } \\
\text { planos de sucessão e promoção, indicações-redes de relacionamento networking); recrutamento extermo (anúncios, } \\
\text { agências de emprego, recrutadores de executivos (headhunters), recrutamento universitário, estagiários, trabalhadores } \\
\text { temporários, ex-funcionários, recrutamento eletrônico - intermet, indicações-redes de relacionamento networking); } \\
\text { seleção (entrevistas, testes de inteligência, de habilidade física, de aptidão, inventários de interesse, provas de } \\
\text { conhecimentos gerais ou específicos, técnicas vivenciais (exemplo: dinâmica de grupo e psicodrama), testes } \\
\text { psicológicos (psicométricos - raciocínio verbal, inteligência lógica, raciocínio espacial e aritmético etc. - e de } \\
\text { personalidade, Big Five). }\end{array}$} \\
\hline
\end{tabular}

Figura 2. Principais pontos abordados na literatura e definição operacional da política

Fonte: adaptado de Demo et al. (2011)

Na visão de Souza, Paixão e Souza (2011), a política de recrutamento e seleção pode ser definida como uma atividade que procura atender às necessidades internas da organização, mediante o emprego de métodos e técnicas específicas, criadas para atrair e escolher os melhores candidatos.

De acordo com Bezerra e Helal (2009), a política de recrutamento e seleção inicia-se com o planejamento da necessidade de pessoal da instituição, sendo que esse planejamento deve estar voltado para o alcance dos objetivos organizacionais. Em seguida, realiza-se a descrição e análise dos cargos, que implica em descrever detalhadamente as atribuições e atividades de um cargo, incluindo os conhecimentos, habilidades e atitudes necessários para que o sujeito possa desempenhar com sucesso as atribuições do cargo. E por fim, recorrem ao recrutamento e seleção, que tratam da atração e identificação de um grupo de candidatos, entre os quais serão escolhidos os que tiverem melhor desempenho para serem contratados.

Bezerra e Helal (2009) mostram que, diante da intensa competição, as organizações têm valorizado as características pessoais em detrimento dos aspectos técnicos dos cargos, sendo necessário aliar as competências técnicas adquiridas na formação dos indivíduos às competências comportamentais (criatividade, flexibilidade, trabalho em equipe, entre outras). Os autores acrescentam que os profissionais de gestão de pessoas devem ser capazes de perceber e identificar essas competências comportamentais em cada um dos candidatos, uma 
vez que as mudanças organizacionais reivindicam competências humanas cada vez mais completas e especializadas.

Nesse sentido, os desafios para a contratação de profissionais qualificados se estendem por todos os setores da economia. Com as inovações tecnológicas e a grande concorrência, o mercado de trabalho busca nos profissionais muito mais do que simplesmente formação profissional, espera-se que o candidato tenha condutas adequadas para garantir produtividade e competitividade, tais como: bom senso, lógica de raciocínio, capacidade de trabalhar em equipe. Ou seja, a dimensão atitudinal é tão importante quanto a cognitiva (Bezerra \& Helal, 2009).

De acordo com Bessi (2011), nos processos de seleção, as organizações tem dado preferência a perfis de indivíduos abertos a mudanças, menos tradicionais nas suas rotinas e concepções, uma vez que as organizações cada vez mais necessitam de colaboradores velozes e sempre prontos a estar no lugar que são convocados para produzir. O objetivo da seleção eficaz é combinar características individuais (capacidade, experiência) com os requisitos do cargo. Essa combinação nem sempre é possível, podendo haver muita interferência no processo devido a subjetividade dos selecionadores (Robbins \& Sobral, 2010).

Dessa forma, o principal mérito da seleção por competências é possibilitar a seleção de indivíduos com fundamento na definição dos conhecimentos, habilidades e atitudes necessárias para cada função, no sentido de facilitar tanto a identificação e aplicação de talentos quanto a implantação de políticas de pessoal e de planos de carreira. A seleção por competência é um processo mais ágil e objetivo, pois apresenta alinhamento com as estratégias da organização. Assim, o objetivo da seleção por competências é criar um perfil de competências para cada cargo dentro da organização, ou seja, elaborar um mapeamento de competências que faça parte do planejamento estratégico da instituição (Souza et al., 2011).

Silva (2012) destaca algumas vantagens do processo de seleção por competências, como: seleção realizada com mais foco, mais objetividade e por um processo sistemático; maior facilidade para prever o desempenho futuro; maior garantia de uma contratação de sucesso; boa adequação do profissional à organização e à atividade a ser desempenhada; turnover ou rotatividade mais baixa e melhora na produtividade; evitar prejuízos com reabertura de processos seletivos e com colaboradores ineficientes; diminuir a influência de opiniões, sentimentos ou preconceitos dos selecionadores; o candidato tende a não mentir, pois deve citar um fato que realmente ocorreu; fornecer dados concretos sobre desempenho do candidato, facilitando o feedback para o candidato; e fortalecer a parceria entre área requisitante e área de seleção. 
Nos processos de recrutamento e seleção, é preciso definir quais canais de comunicação serão utilizados para que se possa atingir um determinado número de candidatos, com o nível de qualificação desejado e quais serão as fontes de recrutamento. Como técnicas de seleção, os autores apresentam os formulários de inscrição; análise de currículos; verificação de referências pessoais; entrevista; testes de habilidades; testes de conhecimento, simulações e testes práticos (Milkovich \& Boudreau, 2000).

A política de recrutamento e seleção da administração pública direta e indireta de qualquer dos Poderes da União, dos Estados, do Distrito Federal e dos Municípios observa o preceito constitucional de prévia aprovação em concurso público para investidura em cargo ou emprego público, excetuando-se as nomeações para cargo em comissão que são de livre nomeação e exoneração. A Lei $n^{\circ} 8.112$ (1990), que trata do regime jurídico único dos servidores públicos civis da União, das autarquias e das fundações públicas federais, estabelece alguns requisitos básicos para investidura em cargo público, como a nacionalidade brasileira, a idade mínima de dezoito anos, dentre outros, sendo que outros requisitos poderão ser exigidos, desde que previamente previstos em lei e dependendo das atribuições do cargo público.

\subsubsection{Envolvimento}

A política de Envolvimento trata-se de proposta articulada da organização, com construções teóricas e práticas, com objetivo de criar um vínculo afetivo com seus colaboradores, contribuindo para seu bem-estar, em termos de reconhecimento, integração, relacionamento, participação, cooperação e comunicação (Demo et al., 2011). A Figura 3 apresenta, de acordo com Demo et al. (2011), os principais pontos abordados na literatura sobre o tema e a definição operacional da política de envolvimento: 


\begin{tabular}{|c|c|c|}
\hline & & Principais pontos abordados na literatura \\
\hline Envolvimento & $\begin{array}{c}\text { Ulrich et al. (1991), } \\
\text { Sisson (1994), } \\
\text { Dessler (2002), } \\
\text { Mathis e Jackson } \\
(2003), \\
\text { Muckinsky (2004), } \\
\text { Siqueira (2008), } \\
\text { Bohlander e Snell } \\
\text { (2009), e } \\
\text { Dietz, Wilkinson e } \\
\text { Redman (2010). }\end{array}$ & $\begin{array}{l}\text { Impacta na satisfação dos colaboradores e nos resultados corporativos. } \\
\text { Contribui para a efetividade organizacional. } \\
\text { Possibilita o bom uso de habilidades dos empregados, reduzindo } \\
\text { desigualdades dentro da organização. } \\
\text { Adaptação dos colaboradores aos seus cargos. } \\
\text { Coerência entre discurso e prática gerencial. } \\
\text { Tratamento respeitoso, atencioso e preocupação com o bem-estar. } \\
\text { Clima de compreensão, cooperação e confiança entre gestores e } \\
\text { subordinados e entre colegas. } \\
\text { Integração dos colaboradores. } \\
\text { Estímulo à participação e comunicação constantes. } \\
\text { Autonomia na realização das tarefas e tomada de decisões. } \\
\text { Reconhecimento e feedback contínuos. } \\
\text { Identificação denecessidades, valores e preocupações dos colaboradores, } \\
\text { estabelecendo relacionamentos. } \\
\text { Existência de canais de comunicação interna. }\end{array}$ \\
\hline \multicolumn{3}{|c|}{$\begin{array}{l}\text { Definição operacional: relacionamento: identificação de competências e expectativas dos colaboradores, tratamento dos } \\
\text { colaboradores baseado em respeito e atenção, e realização de eventos para promover comemoração, diversão e integração } \\
\text { dos colaboradores. Reconhecimento: reconhecimento em forma de elogios, matérias em jormais internos e feedback } \\
\text { constante. Participação: estímulo à participação dos colaboradores nas tomadas de decisão e resolução de problemas. } \\
\text { Comunicação: consideração de ideias, sugestões e reclamações dos colaboradores (comunicação de baixo para cima) e } \\
\text { divulgação de informações importantes para o desempenho do trabalho (comunicação de cima para baixo). }\end{array}$} \\
\hline
\end{tabular}

Figura 3. Principais pontos abordados na literatura e definição operacional da política

Fonte: adaptado de Demo et al. (2011)

Pádua e Honório (2013) destacam que muitos estudiosos sugerem que alguns tipos de vínculos devem ser estabelecidos para que um indivíduo satisfaça necessidades objetivas e subjetivas nas relações mantidas com as organizações. As necessidades de ordem objetiva podem ser associadas aos elementos formais que as organizações oferecem aos seus colaboradores, por exemplo, sistemas inovadores de compensação e oportunidades de desenvolvimento na carreira. Já as necessidades de ordem subjetiva referem-se aos elementos psicossociológicos de satisfação, tais como: reconhecimento, sentimento de pertença, integração e filiação.

Para Kramer e Faria (2007), o vínculo dos indivíduos com a organização acontece quando há envolvimento nas rotinas da organização, o que possibilita o entendimento das tarefas e também dos objetivos da instituição. Freitas (2000) afirma que quando há a reunião de pessoas com a finalidade de concretizar um trabalho ou um projeto em comum faz surgir dois mecanismos psicológicos: a identificação e a idealização com a organização. Além desses dois tipos de vínculos, outros também são estabelecidos para unir o indivíduo à organização, são eles: cooperação, solidariedade, integração (relacionamento), participação nas decisões, reconhecimento e autonomia (Kramer \& Faria, 2007).

De acordo com Freitas (2000), um grupo existe a partir do momento em que seus membros se percebem unidos por uma interdependência que facilita a busca de objetivos, sendo assim, pode-se pressupor a existência de cooperação entre os membros de um grupo. Dessa forma, a cooperação no âmbito organizacional caracteriza-se pelo esforço dos 
dirigentes em incentivar este espírito de equipe entre os colaboradores com o objetivo de que as atividades sejam executadas de forma conjunta e harmônica, facilitando o alcance dos objetivos organizacionais (Schalk \& Curseu, 2010).

Nesse sentido, Schalk e Curseu (2010) acrescentam que as organizações se esforçam em manter relações cooperativas entre os seus funcionários para assegurar que seja capaz de se adaptar mais rapidamente às mudanças do ambiente e se relacionar adequadamente em redes interorganizacionais. Assim, a cooperação é a ação de fazer parte de um projeto comum, ou seja, a ação coletiva pela qual os sujeitos contribuem para o mesmo resultado, mesmo quando o objetivo para este fim é uma imposição (Maggi, 2006).

Pádua e Honório (2013) destacam que a cooperação está intimamente ligada aos laços de solidariedade que as pessoas desenvolvem entre si, sendo que a solidariedade fortalece os laços de reciprocidade, união e ligação mútua entre as pessoas. Assim, por meio deste estado, o outro é reconhecido e elevado à condição de sujeito. A solidariedade é dinâmica e favorece o diálogo entre os membros de um grupo, permitindo que se tornem mais autênticos e integrados.

Nesse sentido, a integração, possibilitada pelo estado de solidariedade, permite que estruturas de acolhimento se desenvolvam, seja na saída ou na chegada de novos membros a um grupo, sem que haja temor dos integrantes que já fazem parte do grupo em perder sua identidade (Pádua \& Honório, 2013).

Senge (1998) defende a ideia do compartilhamento, ou seja, um ato em que todos os membros da empresa tomam parte de uma mesma visão e de um mesmo objetivo, ou seja, algo que gera um sentimento de coletividade e maior coerência ao grupo. Segundo essa visão, a organização precisa propiciar uma abertura participativa para que haja a coesão no grupo ou disponibilize um ambiente que favoreça o envolvimento dos empregados. Assim, para que os colaboradores se sintam entrosados e fazendo parte do grupo a organização precisa implementar um processo de tomada de decisão compartilhado, contemplando os seus funcionários.

Corroborando esse entendimento, Luck (2006) afirma que a participação é importante na formação e manutenção dos vínculos, pois proporciona aos indivíduos a possibilidade de contribuir nas decisões referentes às atividades de uma organização. Dessa forma, a participação favorece as experiências coletivas de trabalho, a socialização das decisões e a divisão de responsabilidades, constituindo-se como elemento fundamental de integração social democrática. Assim, a organização, ao permitir que os empregados participem das decisões, estará favorecendo o reconhecimento e a valorização dos esforços dos empregados. 
No mesmo sentido, Kramer e Faria (2007), colaborando com a discussão, entendem que a partir do momento em que a organização possibilita o compartilhamento das decisões, favorecendo a troca de opiniões e ideias entre os membros do grupo, faz com que os participantes desse ambiente se percebam envolvidos e responsáveis pelos resultados da organização. Assim, nessas condições, o profissional tende a ter um melhor desempenho e a sentir mais vinculado àquela empresa, uma vez que há espaço para emitir sua opinião.

Nesse diapasão, a busca de reconhecimento por parte dos indivíduos é realizada de diferentes formas: pertencer a um grupo profissional específico e valorizado, porque os saberes que os seus membros podem lhe transmitir são essenciais para o desenvolvimento das atividades da organização; manifestar a identificação com o projeto e os objetivos da empresa; absorver os conhecimentos transmitidos; dominar fontes de informação ou meios de coordenação do trabalho, dentre outros (Veloso, 2007). Dessa forma, Zimerman (2000) afirma que o ser humano, ao fazer parte de diferentes grupos, tem a necessidade de se sentir reconhecido e valorizado, e, por consequência, ser aceito, querido e amado.

Por fim, Freire (2008) pontua que a autonomia está diretamente relacionada ao desenvolvimento da pessoa, da sua maneira e capacidade de enfrentar os problemas e dificuldades, cujas soluções serão sempre encontradas de maneira consciente. Por outro lado, a autonomia leva o indivíduo a enfrentar as responsabilidades e as demandas que surgem de suas atitudes e responder pelas consequências dos seus atos. Maggi (2006) complementa dizendo que a autonomia é a capacidade de formatar suas próprias regras, administrar os próprios processos de ação, conduzindo à independência.

\subsubsection{Treinamento, Desenvolvimento e Educação (TD\&E)}

Demo et al. (2011) definem a política de Treinamento, Desenvolvimento e Educação (TD\&E) como uma proposta articulada da organização, com construções teóricas e práticas, que objetiva prover aos colaboradores a aquisição sistemática de competências e estimular a contínua aprendizagem e produção de conhecimento. Os autores selecionaram os principais pontos abordados na literatura sobre o tema e apresentaram a definição operacional da política de TD\&E, conforme Figura 4: 


\begin{tabular}{|c|c|c|}
\hline Política & Autores & Principais pontos abordados na literatura \\
\hline $\begin{array}{c}\text { Treinamento, } \\
\text { Desenvolvimento e } \\
\text { Educação - TD\&E }\end{array}$ & $\begin{array}{c}\text { Goldstein (1996), } \\
\text { Sisson (1994), } \\
\text { Dutra (2001), } \\
\text { Dessler (2002), } \\
\text { Borges-Andrade, Abbad e } \\
\text { Mourão (2006), } \\
\text { Winterton (2007) e } \\
\text { Bohlander e Snell (2009). }\end{array}$ & $\begin{array}{l}\text { Treinamento: esforço da organização para facilitar a aprendizagem } \\
\text { de comportamentos relacionados ao trabalho. } \\
\text { Desenvolvimento: eventos de aprendizagem que capacitam o } \\
\text { indivíduo a atuar em postos de trabalho específicos em um futuro } \\
\text { próximo. } \\
\text { Educação: processos gerais de aprendizagem que propiciam o } \\
\text { crescimento e o amadurecimento individuais de forma ampla, } \\
\text { tomando o colaborador capaz de aprender. } \\
\text { Influência da cultura nacional, setorial e da diversidade cultural. } \\
\text { Estímulo à aprendizagem, ao compartilhamento e à produção de } \\
\text { conhecimento. } \\
\text { Desenvolvimento de competências necessárias ao desempenho das } \\
\text { funções. } \\
\text { Investimento em desenvolvimento e educação. } \\
\text { Treinamentos: levantamento contínuo de necessidades, avaliação } \\
\text { pelos participantes e transferência. } \\
\text { Investimento em métodos modernos de treinamento, } \\
\text { desenvolvimento gerencial e gestão de carreira (educação a distância } \\
\text { e universidades corporativas). }\end{array}$ \\
\hline \multicolumn{3}{|c|}{$\begin{array}{l}\text { Definição operacional: oferta de treinamentos on thejob (internos), extemos, treinamento de aprendizado (uma mistura } \\
\text { de on the job e instruções em sala de aula), métodos modernos de treinamento, desenvolvimento e educação, educação a } \\
\text { distância, palestras e participação em eventos externos como congressos e seminários, incentivo à formação dos } \\
\text { colaboradores por meio do patrocínio total ou parcial de cursos de graduação e pós-graduação nas modalidades presencial } \\
\text { e/ou a distância, cursos de línguas. }\end{array}$} \\
\hline
\end{tabular}

Figura 4. Principais pontos abordados na literatura e definição operacional da política

Fonte: adaptado de Demo et al. (2011)

Nesse contexto de constantes mudanças socioeconômicas, científicas e tecnológicas, o componente intelectual de uma parcela significativa das atividades econômicas cresceu consideravelmente. Além disso, é cada vez maior a demanda por profissionais com maior qualificação, competência e múltiplas habilidades, o que exige um contínuo e permanente aperfeiçoamento para a assimilação de novos valores e para que haja desempenho satisfatório no cargo (Silva \& Silva, 2008).

Dessa forma, os programas de treinamento passam a ser essenciais às organizações, sendo considerados instrumentos eficazes de aprendizagem das habilidades exigidas pelo novo perfil profissional (Meneses, 2007). O conhecimento passa a ter um valor estratégico, levando as organizações a promoverem um esforço pela qualificação contínua dos colaboradores, e em contrapartida surge a demanda pela avaliação do impacto do treinamento no desempenho dos funcionários e das organizações. Assim, avaliar o resultado das ações de treinamento no contexto da gestão do desempenho humano, compreendendo como as variáveis afetam o resultado do treinamento nas organizações, torna-se fundamental para que a área de gestão de pessoas possa tornar o processo de treinamento efetivo (Borges-Andrade, 2002).

Na visão de Coelho Júnior e Borges-Andrade (2008), nem sempre o indivíduo possui as competências necessárias para o bom desempenho das atribuições de seu cargo. Assim, ações de capacitação e de desenvolvimento contínuo, com foco no desenvolvimento de ações 
formais e/ou informais de aprendizagem devem ser enfatizadas, com objetivo de se estimular a aquisição contínua de competências e habilidades necessárias à busca pela excelência na realização da tarefa.

Aguinis e Kraiger (2009) destacam alguns benefícios diretos do treinamento sobre o desempenho organizacional, como: melhoria na produtividade, efetividade, lucratividade, redução de custos e melhoria da qualidade. Os autores acrescentam, ainda, que como efeitos indiretos do treinamento sobre os resultados da organização estão a redução da rotatividade, o aumento do capital social e a melhoria da imagem da empresa.

De acordo com Tavares, Souza e Fogaça (2014), para que as ações de TD\&E possam se aproximar dos objetivos organizacionais é necessário que haja uma compreensão da diferença entre desempenho esperado pela organização e o desempenho do indivíduo. Devido a isso, o processo de treinamento passou a ser estudado a partir de uma abordagem sistêmica, contemplando todos os elementos, como insumo, processamento, resultados e retroalimentação. Assim, para Meneses, Zerbini e Abbad (2010), esses elementos associam-se aos subsistemas de Avaliação de Necessidades de Treinamento (ANT), Planejamento e Execução (também chamado de Desenho Instrucional) e Avaliação de Efeitos.

Para Pilati (2006), a primeira etapa da política de TD\&E, denominada de Avaliação das Necessidades de Treinamento (ANT), objetiva identificar as demandas por treinamento e realizar o alinhamento dessas demandas com o planejamento estratégico da organização. A ANT tem a função de identificar as ações de treinamento que devem ser realizadas com o intuito de suprimir o gap de desempenho dos indivíduos com o que a organização necessita para atingir objetivos de curto, médio e longo prazo. O autor classifica esta etapa como uma das mais importantes para o processo de TD\&E, uma vez que uma análise mal realizada ou distante da realidade organizacional pode prejudicar todas as ações realizadas, ocorrendo dispêndio desnecessário de recursos, financeiros ou não.

Depois de realizada a primeira etapa, dar-se-á início a etapa de Planejamento e Execução das ações de treinamento. Na visão de Pilati (2006), esta etapa também influencia de maneira significativa a otimização dos recursos alocados, pois não faria sentido realizar uma avaliação de necessidades de treinamento que reproduzisse com fidelidade as necessidades organizacionais se essas ações não fossem executadas de forma com que os treinandos absorvessem o conteúdo ministrado. Além disso, faz-se necessário decidir o público-alvo adequado para uma determinada ação de treinamento, evitando que indivíduos sejam treinados sem a devida necessidade, em detrimento dos que realmente deveriam receber a ação de treinamento. 
Por fim, completando a análise da política de TD\&E como sistema, realiza-se a etapa de Avaliação de Efeitos do treinamento, que tem como objetivos controlar o processo, retroalimentar o sistema, tomar decisões sobre o treinamento e torná-lo capaz de provocar mudanças em seu ambiente. Esta etapa ganha maior importância nos casos em que houve falha nas etapas de Avaliação de Necessidades de Treinamento e Planejamento e Execução, podendo evitar desperdícios de recursos ou minimizá-los (Meneses, Zerbini \& Abbad, 2010).

Para Pilati (2006) a Avaliação de Efeitos do treinamento corresponde a uma coleta sistemática de informações, que ocorre em vários momentos da ação de treinamento, com o objetivo de viabilizar a emissão de um julgamento sobre a efetividade das ações de TD\&E. Esse julgamento irá servir como insumo para retroalimentar o sistema, buscando aperfeiçoamento das ações.

As pesquisas na área de TD\&E cresceram nos últimos anos, gerando uma produção teórica consistente. Aguinis e Kraiger (2009), ao realizarem uma revisão bibliográfica entre os anos de 2000 e 2008, confirmaram o crescimento do campo de treinamento e a evolução da educação a distância. Os autores destacam que uma das razões para o crescimento da área se dá em virtude das pressões advindas do atual cenário mundial que requer investimento permanentemente em capacitação por parte das organizações.

Dessa forma, a modalidade de ensino a distância (EAD), nesse cenário de constantes mudanças e do aumento da demanda por aprendizagem para o trabalho, apresenta-se como uma alternativa para ampliar o alcance dos objetivos de capacitação (Zerbini \& Abbad, 2010). No estudo de Torres e Fialho (2009), ao realizar uma revisão do desenvolvimento da educação a distância no Brasil, os autores constataram que as primeiras experiências brasileiras aconteceram a partir de 1950 adotando-se o método da mídia impressa e no ensino por correspondência. Em seguida, passou-se a utilizar diferentes mídias de comunicação como rádio, televisão, fitas de áudio, conferências por telefone e tutorias presenciais, aumentando a interação entre treinandos e instrutores. A partir da década de 1980 começou-se a utilizar um método mais semelhante ao atual, tendo em vista o uso do computador e das novas tecnologias da informação e comunicação.

De acordo com Silva, Gondim, Macêdo e Luna (2012), a importância do uso de novas tecnologias para realizar ações globais de capacitação tem sido potencializada pela possibilidade de ampliar o alcance das ações de capacitação por meio do ensino a distância e da comunicação entre diversas instituições distantes geograficamente. As vantagens dessas ações de capacitação que são mediadas por novas tecnologias são potencializadas pela 
formação de redes organizacionais, que ampliam a comunicação e as oportunidades de aprendizagem colaborativa, com a facilidade propiciada pela internet.

Na administração pública federal, destaca-se o Decreto $n^{\circ} 5.707$ (2006), que instituiu a Política Nacional de Desenvolvimento de Pessoal (PNDP), no âmbito da administração pública federal direta, autárquica e fundacional, que tem, dentre suas finalidades, o desenvolvimento permanente do servidor e a adequação das competências requeridas dos servidores aos objetivos das instituições. De acordo com Fonseca, Meneses, Isidro-Filho e Campos (2013), é possível relacionar a PNDP com as perspectivas teóricas de gestão estratégica de pessoas, as quais preveem o alinhamento dos processos de gestão de pessoas e das competências dos indivíduos à estratégia organizacional.

A política de TD\&E dos servidores públicos é tratada pela Constituição Federal de 1988 que estabelece que a União, os Estados e o Distrito Federal manterão escolas de governo para a formação e o aperfeiçoamento dos servidores públicos, constituindo-se a participação nos cursos um dos requisitos para a promoção na carreira, facultada, para isso, a celebração de convênios ou contratos entre os entes federados. Nesse sentido, escolas de governo na Europa, no Canadá e no Brasil adotam a educação a distância, oferecendo cursos para servidores públicos e para a comunidade. Ainda que seja crescente a quantidade de ações de capacitação ofertadas nessa modalidade no Brasil, a adoção da EAD é recente ou uma novidade para muitas organizações brasileiras, e ainda é ínfimo o número de pesquisas sobre o avanço da modalidade no serviço público brasileiro (Silva et al., 2012).

\subsubsection{Condições de Trabalho}

A política de Condições de Trabalho pode ser definida, a partir de Demo et al. (2011), como uma proposta articulada da organização, com construções teóricas e práticas, que objetiva proporcionar aos colaboradores boas condições de trabalho em termos de benefícios, saúde, segurança e tecnologia. A Figura 5 apresenta os principais pontos abordados na literatura sobre o tema e a definição operacional da política de condições de trabalho (Demo et al., 2011): 


\begin{tabular}{|c|c|c|}
\hline & & Principais pontos abordados na literatura \\
\hline Condições de Trabalho & $\begin{array}{c}\text { Sisson (1994), } \\
\text { Osborn, Hunt e } \\
\text { Schermerhorn (1998), } \\
\text { Ulrich (2001), } \\
\text { Dessler (2002), } \\
\text { Mathis e Jackson } \\
\text { (2003), } \\
\text { Armstrong (2009), } \\
\text { Bohlander e Snell } \\
\text { (2009), e } \\
\text { Loudoun e Johnstone } \\
(2010) .\end{array}$ & $\begin{array}{l}\text { Proteção e cuidados dos colaboradores. } \\
\text { Deve ser escrita e divulgada aos colaboradores. } \\
\text { Incentivo à saúde e à qualidade de vida no trabalho. } \\
\text { Ambiente adequado e condições propícias para a manutenção do bem- } \\
\text { estar fisico, psíquico e mental dos individuos. } \\
\text { Não exposição excessiva a ruídos, substâncias tóxicas, ou excessivas } \\
\text { horas de trabalho, no intuito de diminuir riscos de lesão à saúde } \\
\text { integral dos colaboradores. } \\
\text { Medicina ocupacional: prevenção de doenças relacionadas ao trabalho } \\
\text { e contenção de riscos. } \\
\text { Higiene ocupacional: controle de riscos de contaminação por produtos } \\
\text { químicos e a parte da ergonomia. } \\
\text { Oferta de beneficios básicos e complementares. } \\
\text { Programas de prevenção de acidentes e promoção da saúde. } \\
\text { Ergonomia. } \\
\text { Preocupação com a segurança. } \\
\text { Plano flexível de beneficios (plano cafeteria). } \\
\text { Oferta de materiais, equipamentos e tecnologia adequados ao } \\
\text { desempenho eficaz das funções. } \\
\text { Facilidades e conveniência no local de trabalho. }\end{array}$ \\
\hline \multicolumn{3}{|c|}{$\begin{array}{l}\text { Definição operacional: beneficios: grupos de beneficios e a possibilidade de escolhê-los (plano cafeteria), como horário } \\
\text { flexível de trabalho, telecomutação e creche; bom e bem-aceito plano de saúde, bom estacionamento, convênios com } \\
\text { academias, creches e outros estabelecimentos, opções delazer e facilidades nolocal de trabalho como quadras de esportes, } \\
\text { churrasqueiras, lanchonetes e restaurantes, postos bancários, correios, atendimento médico e psicológico. Saúde: programas } \\
\text { de qualidade de vida no trabalho que visam à promoção do bem-estar físico e emocional das pessoas, programas de } \\
\text { prevenção de doenças e estresse no trabalho, ambiente arejado, bem iluminado, instalações ergonômicas, práticas para } \\
\text { controle do estresse. Segurança: medidas de proteção aos empregados como acesso controlado às instalações e circuitos } \\
\text { internos de TV, existência de comissão interna para prevenção de acidentes, aquisição e manutenção de equipamentos de } \\
\text { segurança como extintores, iluminação de escadas, saídas de emergência e pisos antiderrapantes, adaptações para } \\
\text { portadores de necessidades especiais. Tecnologia: acesso a equipamentos e materiais adequados para o bom desempenho da } \\
\text { função e existência de canais de comunicação para divulgação de informações e integração dos empregados. }\end{array}$} \\
\hline
\end{tabular}

Figura 5. Principais pontos abordados na literatura e definição operacional da política

Fonte: adaptado de Demo et al. (2011)

A qualidade de vida no trabalho geralmente é conceituada com base em seu estado geral de bem-estar no local de trabalho e nas relações que as pessoas têm com este ambiente e com as outras pessoas. No entanto, alguns indicadores da qualidade de vida no trabalho podem ser medidos, como por exemplo: o sentido do trabalho, bem-estar psicológico e o sofrimento psicológico, comprometimento organizacional (afetivo e de continuidade), estresse relacionado ao trabalho, presenteísmo e o equilíbrio entre trabalho e vida privada (Vilas Boas \& Morin, 2013).

Nesse sentido, de acordo com Vilas Boas e Morin (2013), é importante estudar o estresse relacionado ao trabalho, uma vez que os resultados poderão ajudar no entendimento do sentido do trabalho e na qualidade de vida no trabalho. Dentre os modelos existentes para estudar o estresse relacionado ao trabalho, as autoras apresentam o modelo de Cooper (1985), que é frequentemente utilizado nos estudos sobre o tema. O modelo especifica três tipos de fontes de estresse: fatores intrínsecos ao trabalho, fatores psicossociais (incluindo o papel do indivíduo na organização) e os fatores organizacionais (incluindo o desenvolvimento da carreira, estruturas organizacionais e o clima organizacional). 
O arranjo físico das organizações, compreendido como as instalações, o mobiliário, a moldura do ambiente, a disposição dos equipamentos e utensílios, a iluminação, os ruídos, a coloração utilizada, odores, o espaço para se locomover e comunicar-se, interfere diretamente na satisfação dos indivíduos e consequentemente na qualidade de vida no trabalho. Dessa forma, a adequação do ambiente de trabalho pode ser considerada uma forma de contribuir para a satisfação dos colaboradores. Além disso, ambientes agradáveis e saudáveis geram maior produtividade para as organizações (Brum, 2003).

Corroborando esse entendimento, Maranhão e Sá (2013) afirmam que a ergonomia tem por objetivo adequar o ambiente de trabalho às características físicas e psicológicas do ser humano, com vistas a assegurar saúde, segurança e interação do funcionário com o ambiente de trabalho, resultando numa melhor produtividade quando do desenvolvimento das atividades laborais. Assim, os aspectos físicos do ambiente de trabalho, como iluminação, ergonomia e organização do layout, não devem ser negligenciados, uma vez que podem gerar ineficiência das tarefas e a predisposição para doenças causadas pelo trabalho. As doenças podem está ligadas a fatores físicos, biológicos e psicológicos do trabalho (Limongi-França \& Rodrigues, 2007).

De acordo com Diniz (2001), a execução do trabalho em condições de risco para a saúde tem sido uma preocupação para ergonomistas, profissionais da área de saúde e cientistas sociais. Assim, o modelo em saúde do trabalhador busca resgatar o lado humano do trabalho e sua capacidade de proteger os trabalhadores de danos à saúde, tais como: incômodos, desgastes, lesões, muito além da abordagem dos acidentes e doenças. A área da saúde do trabalhador compreende, portanto, o trabalhador como agente de mudanças, com conhecimentos e vivências sobre seu trabalho, compartilhadas coletivamente por meio da participação do controle da nocividade, da definição consensual de prioridades de intervenção e da elaboração de estratégias transformadoras (Lacaz, 2007).

\subsubsection{Avaliação de Desempenho e Competências}

Na visão de Demo et al. (2011), a política de Avaliação de Desempenho e Competências pode ser conceituada como uma proposta articulada da organização, com construções teóricas e práticas, que objetiva avaliar o desempenho e as competências dos colaboradores, com vistas a subsidiar as decisões sobre promoções, planejamento de carreira e desenvolvimento. Os autores selecionaram os principais pontos abordados na literatura sobre 
o tema e apresentaram a definição operacional da política de avaliação de desempenho e competências, conforme Figura 6:

\begin{tabular}{|c|c|c|}
\hline Política & Autores & Principais pontos abordados na literatura \\
\hline $\begin{array}{l}\text { Avaliação de } \\
\text { Desempenho e } \\
\text { Competências }\end{array}$ & \begin{tabular}{|c|} 
Devanna, Fombrun e \\
Tichy (1984), Dutra \\
$(2001)$, \\
Dessler (2002), \\
Mathis e Jackson(2003), \\
Latham, Sulsky e \\
MacDonald (2007), e \\
Bohlander e Snell \\
(2009).
\end{tabular} & $\begin{array}{l}\text { Apresentação de feedbacks aos colaboradores, com relação às metas } \\
\text { atingidas e aos resultados alcançados, para demonstrar a capacidade } \\
\text { da equipe em alcançar resultados cada vez mais expressivos. } \\
\text { Definir o desempenho desejado (metas), de forma a clarificar aos } \\
\text { colaboradores o que deve ser feito. } \\
\text { Observar o desempenho, interpretando resultados. } \\
\text { Tomar decisões com basena avaliação dos resultados alcançados ou } \\
\text { não, de forma a determinar novas metas. } \\
\text { Realizações periódicas. } \\
\text { Desmistificar o caráter punitivo da avaliação. } \\
\text { Subsídio para a elaboração de um plano de desenvolvimento dos } \\
\text { colaboradores e as tomadas de decisão sobre promoções e aumento } \\
\text { de salário. } \\
\text { Discussão (elaboração conjunta) e divulgação aos colaboradores dos } \\
\text { critérios e resultados. }\end{array}$ \\
\hline
\end{tabular}

Figura 6. Principais pontos abordados na literatura e definição operacional da política

Fonte: adaptado de Demo et al. (2011)

O desempenho também pode ser conceituado como uma medida dos resultados obtidos por um indivíduo, uma equipe, uma organização ou um processo. Dessa forma, cada indivíduo é responsável por comprovar a sua utilidade, sua produtividade e sua rentabilidade e, assim, fazer jus ao seu cargo ou função (Gaulejac, 2007). Para Zagonel, Ferraz e Soboll (2012), a organização oferece ao indivíduo uma autonomia controlada, pois a liberdade que lhe foi conferida, na organização e realização do trabalho, é uma contrapartida dos seus resultados, ou seja, por ele respeitar as regras e realizar o trabalho que lhe foi designado.

$\mathrm{Na}$ visão de Barbosa (1996), a política de avaliar as pessoas e suas respectivas produções como um procedimento administrativo regular no interior das organizações começa mais ou menos junto com a revolução nas relações de trabalho trazida por Frederik Taylor. Com a escola das Relações Humanas e sua ênfase eminentemente humanista, a visão da avaliação de desempenho, como um artifício punitivo e controlador da produção, começa a sofrer alterações. A visão do homo economicus, que respondia apenas aos incentivos salariais, foi substituída pelo homo socialis, que responde melhor a incentivos sociais e simbólicos.

De acordo com Pontes (2005), desempenho relaciona-se à qualidade e quantidade de trabalho realizado, bem como ao custo e tempo dispendidos na sua execução. Abrange fatores de eficiência e eficácia no âmbito da organização. Nesse sentido, avaliar significa comparar resultados alcançados com aqueles que eram esperados, sendo que apenas o trabalho previamente planejado deve ser objeto de avaliação. Assim, essa sistemática pressupõe a comparação entre o que se espera do indivíduo em termos de realização (resultado esperado), e a sua atuação efetiva (trabalho realizado), existindo algum mecanismo de acompanhamento, 
que permita corrigir desvios para assegurar que a execução corresponda ao que foi planejado (Grohmann, Cunha \& Silinske, 2013).

Quanto à responsabilidade pela avaliação, as técnicas evoluíram de um modelo de avaliação individual (chefia), por meio do qual o chefe realizava unilateralmente um diagnóstico dos pontos fortes e fracos do subordinado, para outros modelos, como a avaliação bilateral, em que chefe e subordinado discutem em conjunto o desempenho, e, mais recentemente, o modelo de avaliação $360^{\circ}$, que estabelece que a avaliação tem que ser realizada por diversos atores: clientes, pares, chefe e o próprio indivíduo avaliado (Brandão \& Guimarães, 2001).

A avaliação de desempenho passa a adquirir o status de termômetro das necessidades e das realizações das organizações e dos indivíduos, e por meio dela é possível identificar as áreas nas quais o treinamento se faz necessário, verificar se os critérios de seleção utilizados estão realmente adequados, se estão selecionando as pessoas certas para os lugares certos, e se há colaboradores que necessitam ser removidos para serem mais bem aproveitados (Barbosa, 1996).

Para Lucena (1992), o acompanhamento sistemático do desempenho humano permite que a organização possa utilizar de maneira adequada os seus recursos e conduzir eficazmente o desempenho do seu pessoal para resultados positivos. Nesse sentido, a gestão do desempenho funciona como um mecanismo que, aliado a outras tecnologias da gestão, permite à organização administrar estrategicamente seus recursos humanos para a consecução dos objetivos organizacionais.

Coelho Júnior (2011) considera a gestão do desempenho humano no trabalho como uma atividade contínua de planejamento, execução, monitoramento, avaliação e revisão, caracterizada pela interação social ativa entre gestor e o colaborador. A gestão visa direcionar o desempenho tanto do colaborador quanto do próprio gestor no sentido de melhorar os resultados de ambos a partir de ações de reflexão crítica e, por consequência, maximizar o desempenho interno e externo da organização.

Dessa forma, a gestão do desempenho humano possui caráter estratégico, sendo um dos focos de atenção da gestão de pessoas. Seus resultados influenciam as demais políticas: recrutamento e seleção, treinamento e remuneração. Portanto, é um recurso utilizado nas organizações para dimensionamento da qualidade dos seus profissionais, cujo objetivo é identificar o nível de capacitação ou qualificação profissional e o potencial dos colaboradores, analisando esses dados em face dos objetivos organizacionais (Leite et al., 1999). 
A premissa básica da gestão do desempenho humano nas organizações consiste no desenvolvimento de indivíduos e equipes em torno da aquisição de competências relacionadas ao seu trabalho, avançando em direção a objetivos e metas predeterminadas nas organizações, conforme demonstrado na Figura 7. É de fundamental importância a participação dos gestores em todas as etapas da gestão do desempenho, principalmente nas fases de planejamento e monitoramento, e na manutenção dos níveis de motivação e comprometimento por parte dos colaboradores. Os efeitos do contexto de trabalho sobre os indivíduos e equipes devem, também, ser analisados e considerados em cada uma das etapas, uma vez que podem gerar impacto no exercício das atividades e nos resultados esperados (Coelho Júnior, 2011).

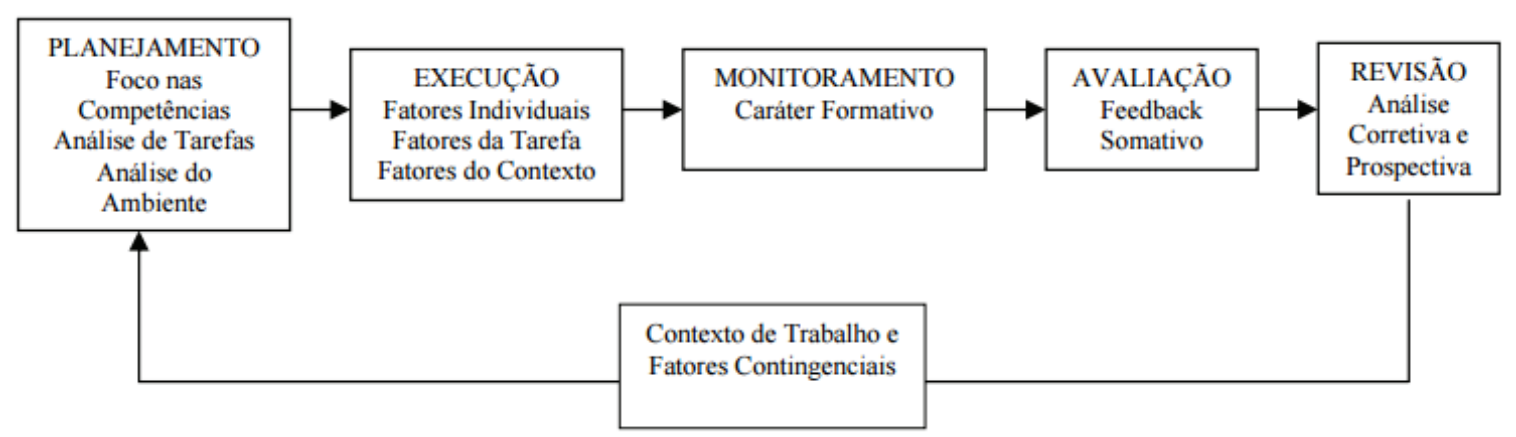

Figura 7. Etapas da gestão de desempenho humano no trabalho Fonte: Coelho Júnior (2011)

De acordo com Abbad (1994) os sistemas de avaliação devem ser justos e imparciais, baseados em padrões de desempenho atingíveis, objetivos e claros, apoiados na realidade dos cargos ou postos de trabalho. Os fatores de avaliação devem ser claramente definidos e os instrumentos precisam exemplificar ações observáveis, de maneira que possam servir como indicadores de desempenho e referenciais seguros para atribuição de escores. Lucena (1992) acrescenta que a organização precisa se preparar adequadamente para a avaliação de desempenho, o que contempla a definição e o treinamento dos avaliadores. A responsabilidade pela avaliação contribui efetivamente para o sucesso do processo implantado.

Espera-se, ainda, que os gestores possam estabelecer critérios de monitoramento e avaliação, além de se assegurar a comunicação contínua e a divulgação de expectativas de desempenho junto ao seu subordinado. A atuação do gestor como coach na orientação dos subordinados deve ser incentivada como uma das atribuições esperada das chefias imediatas (Coelho Júnior, 2011). No entendimento de Pires (2005), a avaliação de desempenho individual objetiva mensurar a performance do indivíduo no exercício das atribuições do cargo ou da função, com foco na contribuição individual para o alcance dos objetivos organizacionais. 
As Administrações Públicas de outros países estão buscando definir papéis e competências necessárias dos dirigentes públicos e formatar sistemas de incentivo ao desempenho. Na Administração Pública brasileira, a ocupação de cargos gerenciais se dá sem requisitos de perfil de competências para o exercício da função. Os gerentes não são avaliados e não há regras sobre os procedimentos para exoneração do cargo, o que propicia a falta de transparência nas decisões de substituição de cargos comissionados, de livre nomeação e exoneração (Fernandes, 2013).

Para Pacheco (2010), a mensuração do desempenho no setor público é um dos pilares mais importantes da nova governança em torno do Estado em rede e tem contribuído para o alcance de múltiplos objetivos, como a transparência de custos e de resultados, a melhoria da qualidade dos serviços prestados e a motivação dos funcionários. Dessa forma, o modelo de gestão por resultados foi então implantado na Administração Pública como forma de romper com o modelo burocrático (Araújo, 2013).

Muitos países adotaram esse modelo com a expectativa de que tal mudança iria reforçar o Estado pela clarificação das missões e objetivos, permitindo às autoridades centrais estabelecer metas de desempenho e monitorar os resultados. A nova gestão pública, centrada nos mecanismos de coordenação, impactou três áreas importantes das organizações: a forma de trabalho em equipe, a forma como as organizações prestam contas do trabalho realizado (accountability) e as formas de fornecimento de serviços públicos (Araújo, 2013).

Na visão de Madureira (2013), para que uma reforma administrativa seja capaz de transformar a Administração Pública em um ente que busque ativamente resultados é necessário que a avaliação de desempenho se torne um paradigma reproduzido, multiplicado e apreendido por toda a organização. Em Portugal, foi lançado em 2004 o Sistema Integrado de Avaliação de Desempenho da Administração Pública, mas até 2013 não havia sido realizado estudos sobre a avaliação do resultado da implementação desse sistema. Esse sistema de avaliação, adotado na Administração Pública de Portugal, sugere que seja aplicada uma filosofia de objetivos em cascata, desde o topo hierárquico até à base operacional.

Para Madureira (2013), as tendências do pensamento administrativo, que perpassam o New Public Management à Governança, demonstram que os dirigentes de topo exercem a função de executores das políticas públicas e de agentes ativos de mudança, tendo, dessa forma, resultados a alcançar e metas a cumprir. $\mathrm{O}$ autor entende que não há sentido em se estabelecer objetivos, metas e indicadores de desempenho aos servidores sem que se faça o mesmo aos dirigentes de topo. 
Na administração pública federal, o Decreto $n^{\circ} 7.133$ (2010) regulamenta os critérios e procedimentos gerais a serem observados para realização das avaliações de desempenho individual (servidor) e institucional (organização) para grande parte das Carreiras e Planos Especiais de Cargos do Poder Executivo, incluindo o Ministério do Meio Ambiente, com a finalidade de pagamento da gratificação de desempenho. O Decreto conceitua avaliação de desempenho como sendo o monitoramento sistemático e contínuo da atuação individual do servidor e institucional dos órgãos e das entidades de lotação dos servidores, tendo como referência as metas globais e intermediárias destas unidades.

Nesse sentido, a avaliação de desempenho individual deverá ser realizada com base em critérios e fatores que reflitam as competências do servidor, aferidas no desempenho individual das tarefas e atividades que lhe foram atribuídas. Além do cumprimento das metas de desempenho individual, o Decreto exige que sejam avaliados os seguintes fatores mínimos: produtividade no trabalho, com base em parâmetros previamente estabelecidos de qualidade e produtividade; conhecimento de métodos e técnicas necessários para o desenvolvimento das atividades referentes ao cargo efetivo na unidade de exercício; trabalho em equipe; comprometimento com o trabalho e cumprimento das normas de procedimentos e de conduta no desempenho das atribuições do cargo. O órgão ou entidade ainda poderá incluir um ou mais dos seguintes fatores: qualidade técnica do trabalho; capacidade de autodesenvolvimento; capacidade de iniciativa; relacionamento interpessoal e flexibilidade às mudanças.

Já avaliação de desempenho institucional, nos termos do Decreto, visa a aferir o alcance das metas organizacionais, podendo considerar projetos e atividades prioritárias e condições especiais de trabalho, além de outras características específicas. As metas referentes à avaliação de desempenho institucional deverão ser segmentadas em: metas globais, elaboradas, quando couber, em consonância com o Plano Plurianual (PPA), a Lei de Diretrizes Orçamentárias (LDO) e a Lei Orçamentária Anual (LOA) e metas intermediárias, referentes às equipes de trabalho.

Os critérios e procedimentos específicos da avaliação de desempenho individual e institucional e de atribuição das gratificações de desempenho regulamentadas pelo referido Decreto deverão ser estabelecidos em ato do dirigente máximo do órgão ou entidade ou do Ministro de Estado ao qual o órgão ou entidade esteja vinculado, observada a legislação específica de cada gratificação de desempenho. 


\subsubsection{Remuneração e Recompensas}

A política de Remuneração e Recompensas é conceituada por Demo et al. (2011) como sendo uma proposta articulada da organização, com construções teóricas e práticas, que objetiva recompensar o desempenho e as competências dos colaboradores em termos de remuneração e incentivos. A Figura 8 apresenta os principais pontos abordados na literatura sobre o tema e a definição operacional da política de remuneração e recompensas (Demo et al., 2011):

\begin{tabular}{|c|c|c|}
\hline & Autores & Principais pontos abordados na literatura \\
\hline $\begin{array}{l}\text { Remuneração e } \\
\text { Recompensas }\end{array}$ & \begin{tabular}{|} 
Devanna, Fombrun e \\
Tichy (1984), \\
Sisson (1994), \\
Hipólito (2001), \\
Dutra (2001), \\
Dessler (2002), \\
Bohlander e Snell (2009), e \\
Gerhart (2010).
\end{tabular} & $\begin{array}{l}\text { Principais decisões: como pagar e quanto pagar. } \\
\text { Deve considerar fatores legais, institucionais, culturais e } \\
\text { mercadológicos. } \\
\text { Dificuldade de se especificar e mensurar o desempenho. } \\
\text { Necessário alinhamento dos fatores contextuais às estratégias traçadas } \\
\text { pela área de GP. } \\
\text { Remuneração compativel com a formação. } \\
\text { Remuneração compativel com as oferecidas no mercado. } \\
\text { Existência de incentivos como prêmios e promoções. } \\
\text { Plano de carreira/progressão funcional claramente definido e } \\
\text { conhecido por todos. } \\
\text { Consideração das expectativas e sugestões dos colaboradores, } \\
\text { recompensas customizadas. } \\
\text { Remuneração condicionada aos resultados. }\end{array}$ \\
\hline \multicolumn{3}{|c|}{$\begin{array}{l}\text { Definição operacional: remuneração: salário compativel com competências e formação e salário competitivo } \\
\text { (compativel com os oferecidos no mercado para a função). Incentivos: promoções viabilizadas por planos de carreira } \\
\text { claramente definidos e conhecidos por todos, bônus, prêmios, opções de ações, participação nos lucros, funções } \\
\text { comissionadas. }\end{array}$} \\
\hline
\end{tabular}

Figura 8. Principais pontos abordados na literatura e definição operacional da política

Fonte: adaptado de Demo et al. (2011)

O gerenciamento das recompensas passou a ser um dos elementos mais importantes das organizações, pois é este gerenciamento que direciona, motiva e remunera o trabalho e a contribuição das pessoas (Silva, 2013). Para Wood Jr e Picarelli Filho (2004), as organizações necessitam implementar uma nova abordagem da remuneração, que contorne as dificuldades existentes e que esteja atenta a quatro aspectos: o alinhamento do esforço individual com as diretrizes organizacionais; a orientação para o processo e para os resultados; o favorecimento de práticas participativas; e o desenvolvimento contínuo do indivíduo. Os autores concluem que a questão principal é mudar a visão usual da remuneração como fator de custo em visão da remuneração como fator de aperfeiçoamento da organização, impulsionando processos de melhoria e aumento de competitividade.

De acordo com Silva (2013), as recompensas podem ser classificadas como financeiras e não financeiras. As financeiras podem ser divididas em direta (remuneração pelos serviços prestados) ou indiretas (benefícios). Já as não financeiras são, por exemplo, as oportunidades de crescimento, autonomia e liberdade. Dentre as diversas possibilidades de remuneração e as diferentes combinações que a literatura apresenta, Coelho e Roglio (2010) 
estudaram as seguintes formas de remuneração: funcional, benefícios, remuneração baseada em competências, participação nos lucros e/ou resultados, participação acionária e prêmios e bônus. As autoras sintetizaram o principal conceito para cada forma de remuneração estudada, conforme apresentado na figura abaixo:

\begin{tabular}{|l|l|}
\hline \multicolumn{1}{|c|}{ Formas de Remuneração } & \multicolumn{1}{|c|}{ Conceito } \\
\hline Remuneração funcional & O valor do salário fixo é definido com base no cargo que o empregado ocupa. \\
\hline Remuneração baseada em competências & $\begin{array}{l}\text { É determinada com base no conjunto de conhecimentos, habilidades e atitudes } \\
\text { que os funcionários desenvolvem e aplicam no desempenho das suas } \\
\text { atividades, deslocando o foco do cargo para o individuo. }\end{array}$ \\
\hline Beneficios & $\begin{array}{l}\text { Correspondem à remuneração indireta, constituem uma complementação } \\
\text { salarial que, quando oferecida de forma espontânea pela empresa, possui a } \\
\text { vantagem de agregar maior valor à remuneração do funcionário. }\end{array}$ \\
\hline Participação nos lucros e/ou resultados & $\begin{array}{l}\text { Programa de remuneração variável que, por intermédio de recompensa } \\
\text { monetária, reconhece eremunera os empregados com base: a) no alcance ou } \\
\text { superação de metas definidas, negociadas e contratadas previamente ou b) no } \\
\text { lucro obtido pela organização. }\end{array}$ \\
\hline Participação acionária & $\begin{array}{l}\text { Componente da remuneração que oferece ao funcionário a co-propriedade da } \\
\text { empresa ao possibilitar distribuições de ações, venda de ações, opções de } \\
\text { compra, ações virtuais e direitos sobre valorização de ações. }\end{array}$ \\
\hline Prêmios e bônus & $\begin{array}{l}\text { Programa de remuneração variável, que consiste no pagamento de prêmios } \\
\text { como compensação à consecução de metas de desempenho individual e/ou } \\
\text { grupal, planos de sugestões ou realização de trabalhos especificos. }\end{array}$ \\
\hline
\end{tabular}

Figura 9. Conceitos das Formas de Remuneração

Fonte: Coelho \& Roglio (2010)

Para Theotônio, Reis Neto e Lopes (2013), a gestão da remuneração nas organizações pode ser dividida em três eixos: (i) remuneração funcional: utiliza como referência o cargo para a consolidação dos planos de cargos e salários (salário mensal, 13º salário e férias); (ii) remuneração variável: caracteriza-se pelo reconhecimento da contribuição dos colaboradores como fator a ser remunerado (prêmios, participação nos lucros e resultados, participação acionária e remuneração por habilidades e competência); e (iii) benefícios: seguro de vida, assistência médica, transporte, cesta básica, seguro de acidentes pessoais, assistência odontológica e incentivo educacional.

A remuneração baseada em competência tem como objetivo remunerar os profissionais por suas características pessoais e alinhar as capacidades dos colaboradores com as estratégias da organização. Para implantar esse sistema remuneratório a organização necessita identificar as competências necessárias para cada posto de trabalho. As competências devem ser certificáveis e medidas segundo padrões que deverão ser estabelecidos pela organização (Carbone, Brandão, Leite \& Vilhena, 2011; Silva, 2013). De acordo com Dutra (2004), definir padrões internos de equidade torna-se fundamental para criar critérios de recompensa justos e duradouros, que propiciem para as pessoas um ambiente de segurança e justiça. $\mathrm{O}$ autor acrescenta que a organização, ao estabelecer esses padrões, 
estimula os colaboradores a ampliar sua contribuição, uma vez que se torna perceptível a remuneração diferenciada para diferentes contribuições.

Já os benefícios são chamados de remuneração indireta, uma vez que, usualmente, são concedidos como condição de emprego e não mantém relação direta com o desempenho, sendo destinados a proporcionar melhor qualidade de vida aos funcionários (Hanashiro, 2008). Na visão de Carvalho, Lustri, Rocha e Souza (2011), atualmente os programas de benefícios objetivam contribuir para que a organização sustente uma posição competitiva favorável na atração e retenção de talentos. Para os autores há três tipos de benefícios: os de seguros (saúde e vida), de complementação (planos de previdência social) e de serviços (assistência à educação, serviços de lazer, financeiros e jurídicos, auxílio-transporte, assistência a compras).

Outra forma de remuneração é a participação nos lucros e/ou resultados, que é utilizada, conforme mencionado por Theotônio et al. (2013), para: (i) aumentar a produtividade, incentivando os colaboradores a trabalhar de forma eficaz e eficiente para o alcance dos objetivos organizacionais; (ii) atrair e reter profissionais mais qualificados, majorando a remuneração total ao longo do tempo e diminuindo a rotatividade de pessoal; (iii) integrar o capital e o trabalho permitindo ao empregado usufruir parte da riqueza por ele produzida; e (iv) incentivar a colaboração entre os empregados, favorecendo o trabalho em equipe.

A participação acionária é o direito que o empregado tem de comprar um lote de ações da empresa por um determinado preço, dentro de um prazo previamente estabelecido. No entanto, essa forma de remuneração somente pode ser utilizada em Sociedades Anônimas ou Sociedades por Ações, não obrigatoriamente de capital aberto (Marras, 2012). De acordo com Theotônio et al. (2013), os principais objetivos da participação acionária são atrair, reter e motivar os empregados, alinhar interesses entre dirigentes e acionistas e maximizar o desempenho em longo prazo.

A última forma de remuneração são os prêmios e bônus, e consistem no pagamento, em caráter eventual, pelo alcance de metas preestabelecidas com tempo de duração predeterminado. Os prêmios e bônus são concretizados por meio de bens, serviços ou viagens, e tem por objetivo recrutar e reter os empregados com o perfil desejado pela empresa. Esse tipo de remuneração, normalmente, é vinculado ao grau de envolvimento dos empregados com os programas de qualidade, segurança, desenvolvimento e resultados operacionais alcançados (Theotônio et al., 2013). 
Com base no exposto, e de acordo com Wood Jr e Picarelli Filho (2004), a gestão da remuneração pode ser indicada como um fator crítico e conflagrado no campo da gestão de pessoas, com maior destaque em organizações públicas, uma vez que há grandes diferenças em comparação aos modelos vigentes no setor privado. Segundo Bergue (2007), essas diferenças são devidas não somente aos aspectos de cultura e da natureza das relações de poder existentes nestes distintos espaços organizacionais, mas principalmente à existência de preceitos constitucionais e legais que vinculam as estruturas remuneratórias no setor público.

As diretrizes básicas para a composição remuneratória dos servidores públicos são encontradas no artigo 39 da Constituição Federal de 1988, que prevê a existência de dois modelos básicos de remuneração, o de remuneração fixa (simples) e o de remuneração variável (composto). A remuneração fixa corresponde a uma parcela única que é expressamente atribuída a agentes públicos específicos, sendo denominada de subsídio. Já a remuneração variável é composta por uma parcela fixa (vencimento básico), acrescida de outra integrada pelo que comumente se denomina vantagens pecuniárias, como os adicionais, gratificações, dentre outros (Bergue, 2007).

A proposta do modelo de remuneração variável é de que a remuneração dos profissionais deve ser, pelo menos em parte, proporcional ao seu desempenho e aos resultados alcançados. No serviço público, há atividades cujo produto (resultado) pode ser mensurado individualmente, contudo há outras que não dispõe desse mecanismo. Dessa forma, costumase avaliar o desempenho dos servidores em relação à realização de suas atividades, que é passível de verificação e avaliação. No entanto, a legislação prevê parâmetros conservadores para a aferição do desempenho de servidores públicos, como: pontualidade, disciplina, cortesia, entre outros, e apenas mais recentemente a noção de produtividade vem sendo incluída (Bergue, 2007).

Mesmo havendo a possibilidade legal de definição da relação entre a maior e a menor remuneração (art. 39, § $5^{\circ}$, da Constituição Federal/1988) do serviço público, são frequentemente encontrados grandes desequilíbrios remuneratórios, que podem ser capazes de comprometer a frágil harmonia das relações funcionais no ambiente organizacional. Devido a isso, os servidores menos favorecidos, em virtude da situação de desequilíbrio remuneratório, ficam insatisfeitos profissionalmente, em geral, por frustrações que reforçam o ciclo de percepção de desprestígio profissional ou mesmo pessoal (Bergue, 2007).

Para Saravia (2006), os governos podem organizar o sistema de trabalho dos servidores públicos de duas formas: em sistema de emprego, no qual o servidor é recrutado para exercer um cargo com funções específicas; ou em sistema de carreira, em que o servidor 
é recrutado para um corpo ou organização, tendo, nesse caso, mais perspectivas para ascensão dentro do órgão. No Brasil, predomina o sistema de carreira, porém utiliza-se a estrutura de cargos, na composição das carreiras, o que pode ser considerado uma forma de reconhecimento de uma estrutura burocrática que não incentiva o desenvolvimento dos servidores (Salles \& Nogueira, 2006).

Por outro lado, Bergue (2007) acrescenta que algumas iniciativas recentes tem proporcionado novo ânimo para o aperfeiçoamento desta área da gestão de pessoas, como as mudanças trazidas pela reforma administrativa, instituída por meio da Emenda Constitucional n $19 / 1998$, acerca da possibilidade de instituição de conselhos de política de administração e remuneração de pessoal, além de prêmios de produtividade (artigo 39, caput e $\S 7^{\circ}$, da Constituição Federal/1988). Nesse sentido, essas mudanças, além de possibilitar a modificação dos modelos remuneratórios tradicionais, vêm corroborar a necessidade de formatação de sistemas remuneratórios mais aderentes à realidade que vem operando na administração pública, dando destaque para a expressão humana.

Para Silva, Balassiano e Silva (2014), a partir da Constituição Federal (1988), o desenvolvimento dos servidores na carreira ficou limitado a progressões funcionais previstas para cada cargo e carreira, não permitindo a ascensão de cargos. A ascensão exige que o servidor seja aprovado em um novo concurso público, pois não há mais previsão legal para a seleção interna de pessoal. Tal forma de promoção foi extinta sob o argumento de que a seleção por concurso público favorece a meritocracia e combate o nepotismo e o fisiologismo da gestão pública (Secchi, 2009).

Meyer e Smith (2000), ao analisarem o impacto que as políticas e práticas de gestão de pessoas podem exercer sobre comprometimento organizacional, acrescentam que as políticas e práticas representam mecanismos privilegiados de desenvolvimento do comprometimento organizacional afetivo e normativo, uma vez que as referidas políticas demostram o apoio, o tratamento isonômico e o suporte da organização para com os seus trabalhadores. Os autores defendem, ainda, que as políticas e práticas de gestão de pessoas da organização podem contribuir para o comprometimento afetivo se forem vistas como uma evidência do empenho que a organização tem com os seus trabalhadores.

\subsection{Comprometimento Organizacional}

A pesquisa sobre comprometimento organizacional é caracterizada pela diversidade de definições e modelos teóricos e tem sido objeto de interesse de pesquisadores e gestores há 
muitos anos. Bastos e colaboradores (2008), ao revisarem a literatura que trata sobre os vínculos que se estabelecem entre indivíduos e organizações, ressaltam que Mowday, Porter e Steers (1982) identificaram diferentes definições e enfoques relacionados ao tema comprometimento organizacional.

Nesse sentido, a vontade que o indivíduo tem para desenvolver suas atividades e a lealdade para com o sistema social das suas relações laborais diferencia-se da forma de relacionamento de um membro com o sistema como um todo. A maneira pela qual as metas da organização e as do indivíduo se tornam crescentemente integradas e harmônicas complementa-se pelas identidades da pessoa e da organização vinculadas por intermédio das atividades e da orientação para o desempenho de seu trabalho (Bastos e colaboradores, 2008).

De acordo com Botelho e Paiva (2011), mesmo convivendo com inúmeras definições de comprometimento organizacional, algumas dimensões de significados comuns podem ser percebidas, tais como: identificação, apego, envolvimento com objetivos e valores, exercer esforço, o desejo de permanecer, de continuar e o sentimento de orgulho por fazer parte da organização. Para esses autores, o comprometimento vai além de uma postura de lealdade passiva com a organização. Assim, comprometimento envolve um relacionamento ativo que propicie bem-estar para os indivíduos na organização.

Flauzino e Borges-Andrade (2008) trazem à luz os estudos de Becker (1992) que, ao rever pesquisas sobre comprometimento organizacional, concluiu pela existência de dois aspectos que comumente são tratados nesses estudos: as bases de comprometimento (afetiva, instrumental, normativa, dentre outras) e os focos (organização, carreira e sindicatos). Assim, as bases correspondem aos motivos que levam ao comprometimento e os focos podem ser considerados os alvos dos vínculos estabelecidos pelo trabalhador.

\subsubsection{As bases do comprometimento: afetiva, instrumental e normativa}

A abordagem predominante de comprometimento organizacional, a partir dos trabalhos de Mowday, Porter e Steers (1982), foi o enfoque na base afetiva. Esses trabalhos reconhecem a existência de uma relação comportamental para definir o comprometimento, mas enfatizam a natureza afetiva do processo de identificação do indivíduo com os objetivos e valores da organização. Desse modo, a abordagem afetiva frisa o aspecto atitudinal do comprometimento (Botelho \& Paiva, 2011).

Botelho e Paiva (2011) lembram que, em decorrência dos trabalhos desenvolvidos por Mowday, Porter e Steers (1979), foi possível a criação e validação de um instrumento para 
mensurar o comprometimento organizacional chamado de Organizational Commitment Questionnaire (OCQ). No Brasil, diversos pesquisadores validaram o referido instrumento, iniciado por Borges-Andrade, Asanasief e Silva (1989), obtendo alto índice de consistência interna.

$\mathrm{Na}$ visão de Bastos e colaboradores (2008), no enfoque instrumental ou de continuação - referenciado nos trabalhos de Becker (1960) - o indivíduo pode sofrer influências do receio da instabilidade, caso deixe a instituição. Tal enfoque destaca o tempo de trabalho na organização e a sensação de receio e insegurança, em lugar do prazer, em virtude do modo como é estabelecida a relação entre indivíduos e organizações.

A composição do comprometimento instrumental pode ser resumida em quatro itens: i) perdas sociais no trabalho: receio de perder a estabilidade no trabalho, a relação de amizade com os colegas de trabalho, e o prestígio do cargo; ii) perdas de investimentos feitos na organização: receio de perder o tempo despendido com capacitação e os esforços realizados para chegar na posição atual; iii) perdas de retribuições organizacionais: receio de perder o bom salário e os benefícios oferecidos pela organização; iv) perdas profissionais: receio de prejudicar a carreira em virtude do tempo que se levaria para se ter o respeito em uma nova empresa e de demorar a se acostumar com o novo ambiente e com o novo trabalho (Botelho \& Paiva, 2011).

No enfoque normativo, os indivíduos agem de determinada maneira por acreditarem que é correto e moral. Essa abordagem é fundamentada nas pesquisas de Wiener (1982), conforme lembrado por Medeiros et al. (2003). Para Bastos (1993), esse enfoque articula dois planos de análise: o organizacional, com destaque para a cultura, e o individual, mediado pela motivação e pelo comportamento.

A partir dos anos 1990, o comprometimento organizacional passou a ser conceituado como um construto tridimensional. $O$ modelo mais utilizado nas pesquisas de comprometimento foi desenvolvido por Meyer e Allen (1991), que uniu as três bases do comprometimento: afetiva, instrumental e normativa.

No Brasil, as pesquisas sobre comprometimento organizacional foram iniciadas, na década de 1990, utilizando o modelo unidimensional, baseado na dimensão afetiva, destacando-se a pesquisa realizada por Bastos, em 1993 (Nascimento, 2013). A partir de 1999, verificou-se que as pesquisas passaram a ser norteadas pelas mesmas dimensões do modelo tridimensional de Meyer e Allen (1991) e demonstraram o interesse dos pesquisadores em tentar verificar a influência da gestão estratégica de pessoas no comprometimento organizacional por diversas vertentes (Nascimento, 2013; Ventura, 2012). 
Rodrigues e Bastos (2011), ao realizarem um estudo sobre a construção teórica do construto comprometimento, sugeriram uma revisão do modelo tridimensional de Meyer e Allen (1991), propondo a retirada da base de instrumental ou de continuação, em virtude de sua sobreposição com o entrincheiramento organizacional. Os autores defendem que situações de permanência do indivíduo na organização por necessidade não podem ter relação conceitual com o comprometimento organizacional.

Nesse diapasão, Nascimento (2013) traz à colação alguns estudos que evidenciam que a base normativa estaria abarcada pela base afetiva, constituindo, assim, uma situação de redundância conceitual. A autora cita que Meyer, Stanley, Herscovich \& Topolnytsky (2002) atestaram a forte correlação entre as bases afetiva e normativa, pois havia grandes evidências de que ambas compartilhavam os mesmos antecedentes e consequentes. Bandeira, Marques e Veiga (1999) também discutem essa possibilidade após encontrarem evidências de que ambas são estimuladas por preditores comuns, como, por exemplo, determinadas práticas de gestão. Cohen (2007), por sua vez, acredita que o comprometimento normativo constitui alguns fatores antecedentes do comprometimento afetivo.

Nesse sentido, Rodrigues, Gondim, Bastos e Sakamoto (2013) consolidaram vários argumentos, com objetivo de reestruturar a agenda de pesquisa na área, propondo, em resumo, que: i) a essência central do comprometimento é a base afetiva (Rodrigues \& Bastos, 2010; Solinger, Olffen \& Roe, 2008); ii) a base instrumental ou de continuação se sobrepõe ao vínculo de entrincheiramento, sendo defendida sua retirada do conceito de comprometimento e incorporação ao conceito de entrincheiramento, em virtude de inconsistências empíricas observadas nas pesquisas (Meyer et al., 2002; Blau, 2001; Blau \& Holladay, 2006; Rodrigues \& Bastos, 2011); e iii) o comprometimento afetivo e o entrincheiramento organizacional são vínculos distintos e geram perfis de vínculos diferenciados, embora estejam correlacionadas com sinal positivo.

Soma-se a isso a evidência, demonstrada por Nascimento (2013), de que a base normativa do comprometimento estaria abarcada pela base afetiva (Meyer et al., 2002; Bandeira et al., 1999; Cohen, 2007). Em complementação, Beck e Wilson (2001) recomendam que, nas pesquisas de comprometimento, sejam monitoradas as diferenças individuais nas experiências de trabalho e nas características pessoais dos empregados. Isso permite a identificação das variáveis que influenciam as relações encontradas entre tempo de serviço na organização e o comprometimento. Os autores sugerem, ainda, pesquisas chamadas trans-sequenciais, que utilizam cortes transversais e longitudinais para combinações e comparações dos resultados. 
Segundo Borges-Andrade e Pilati (2001), apesar da gama de estudos sobre comprometimento, a dimensão comportamental tem sido negligenciada, uma vez que são raras as pesquisas sobre comprometimento com foco na avaliação dos comportamentos expressos, surgindo, assim, uma lacuna na agenda de pesquisa. Mais raros ainda são as pesquisas que tem por objetivo integrar as abordagens comportamentais e atitudinais, que possibilitam observar a coerência entre a fala e a ação do indivíduo (Nascimento, 2013). Levando em consideração essa perspectiva, estudos como o de Menezes (2006) tem buscado construir um conceito de comprometimento organizacional contemplando as variáveis atitudinais e comportamentais, de forma simultânea.

Por outro lado, ao analisar a natureza dos vínculos em diferentes contextos públicos e privados, Bastos e Borges-Andrade (2002) encontraram evidências de que na administração pública direta predomina baixo comprometimento organizacional, exceto quando analisado o comprometimento com a carreira. Neste caso, o comprometimento dos servidores é maior quando comparado ao comprometimento com a organização.

\subsubsection{Os focos do comprometimento: organização e carreira}

Dentre os estudos de comprometimento, a dimensão organização mereceu maior destaque para os pesquisadores do assunto. De acordo com Rowe, Bastos e Pinho (2011), as investigações com foco na carreira eram pouco exploradas até meados dos anos 1990.

Rodrigues et al. (2013), ao final da pesquisa que buscou compreender como os vínculos de comprometimento e entrincheiramento se desenvolvem, sugerem que nos próximos estudos sobre a dinâmica dos vínculos seja considerado o foco na carreira, além do foco na organização, e que seja realizada a triangulação dos dados de origem quantitativa e qualitativa para maior compreensão dos fenômenos.

Uma organização é formada pela reunião de pessoas que cumprem determinada função para a consecução de objetivos, que devem ser condizentes com a missão ou finalidade da organização, e que designa a sua razão de existir. Dessa forma, a interação entre seus membros se torna condição para o seu funcionamento, o que supõe a existência de algum tipo de vínculo entre os integrantes da organização, e entre eles e a própria organização (Kramer \& Faria, 2007).

De acordo com Dessler (1996), o conceito de comprometimento com a organização originou-se de estudos que buscavam explorar as relações entre empregado e organização. $\mathrm{O}$ 
que motivava esses estudos era o pensamento de que empregados comprometidos teriam maior potencial e trariam maior desempenho para a organização.

A necessidade do comprometimento surge a partir da nova natureza das tarefas dos profissionais. Os imperativos de qualidade, serviço e mudança rápida impuseram alterações drásticas na forma de gerenciamento das organizações sociais, com destaque para as organizações públicas, que também passam por mudanças e pela necessidade de adaptação às novas demandas de bens e serviços e formas de gerenciamento de pessoas (Dessler, 1996).

O comprometimento evidencia a sincronia das metas individuais do profissional ou do servidor público com as metas institucionais. Dessler (1996) acrescenta que foi iniciada a era da imprevisibilidade das demandas, da inovação e da iniciativa, e que, consequentemente, o comprometimento dos funcionários não é apenas louvável, mas indispensável.

Ressalta-se que profissionais com alto grau de comprometimento com a organização são aqueles que permanecem na empresa, como forma de retribuição de benefícios recebidos. A lealdade com a organização é a forma que um profissional encontra para manter o vínculo com a instituição (Soldi \& Zanelli, 2006).

Kramer \& Faria (2007) listam alguns elementos que consideram ser constitutivos dos vínculos organizacionais, como: identificação com a organização, sentimento de pertença, cooperação nas atividades, participação nas decisões, idealização da organização, reconhecimento e valorização dos indivíduos, solidariedade, integração entre os membros, crescimento e desenvolvimento pessoal e profissional e autonomia.

O comprometimento com a carreira pode ser conceituado como o link psicológico entre o trabalhador, no caso do serviço público, o servidor, e sua carreira, e é baseada na relação afetiva (Lee, Carswell \& Allen, 2000). Para Bastos (1994), esse vínculo afetivo se relaciona com as linhas consistentes de ação que permitem a construção de uma trajetória e o crescimento no campo ocupacional, dentro de uma organização específica ou em várias organizações ou ocupações.

Rowe et al. (2011) entendem que o comprometimento com a carreira decorre das escolhas do trabalhador e dos processos que permeiam seu ingresso na organização. Esse comprometimento envolve também o desenvolvimento de objetivos de carreira, a identificação do trabalhador com a carreira e a expressão de seus valores profissionais e vocacionais. Na visão de Goulet e Singh (2002), um trabalhador - inclusive no serviço público - que dedique energia e persista na busca de seus objetivos pessoais de carreira poderá ser considerado como detentor de alto nível de comprometimento. 
As primeiras pesquisas sobre comprometimento com a carreira foram realizadas com base em um modelo unidimensional, idealizado por Blau (1985). O modelo era composto por uma escala de sete itens e foi utilizado também nas primeiras pesquisas realizadas no Brasil. Com a proposta de aprimorar as pesquisas sobre comprometimento na carreira, surge o modelo multidimensional criado por Carson e Bedeian (1994), pelo qual podem ser mensurados os fatores de identidade, resiliência e planejamento de carreira (Rowe et al., 2011; Bastos, 1994).

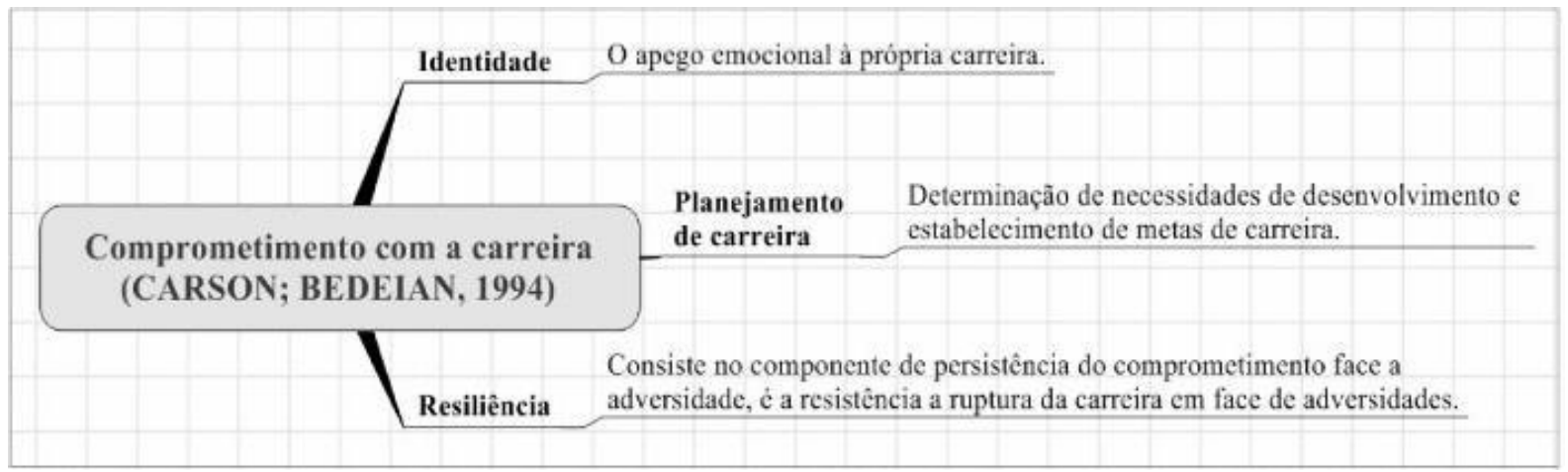

Figura 10. As dimensões do comprometimento com a carreira

Fonte: elaborado por Rowe et al. (2011), a partir de Carson \& Bedeian (1994).

O comprometimento com a carreira, além de ser um vínculo importante no contexto do trabalho, se torna indispensável em um ambiente organizacional que requer o autogerenciamento do desempenho, de acordo com metas e objetivos que expressam as demandas organizacionais e as necessidades e expectativas pessoais (Rowe et al., 2011).

Nessa mesma linha, Somech e Bogler (2002) afirmam que no contexto atual os profissionais necessitam constantemente tomar decisões em um curto espaço de tempo, não podendo ser facilmente supervisionados por terceiros, e os clientes não possuem conhecimento suficiente para avaliar o serviço prestado. Essa situação é facilmente encontrada na administração pública brasileira, principalmente na área de serviços sociais, de saúde, de previdência, e até mesmo de educação. Dessa forma, a qualidade do desempenho do funcionário ou do servidor público pode ser influenciada pelo nível de identidade que ele tem com a carreira (Rowe et al., 2011).

\subsection{Relação entre Políticas e Práticas de Gestão de Pessoas e Comprometimento Organizacional}

De acordo com Borges, Marques e Adorno (2006), apesar do desenvolvimento tardio da área de gestão de pessoas no Brasil, percebe-se que há um grande esforço dos profissionais dessa área no sentido de torná-la mais estratégica, ou seja, alinhar suas atividades com a 
estratégia e os objetivos organizacionais. Os autores acrescentam que a partir da década de 1990, avanços significativos vem sendo realizados nessa área, na medida em que se tem implementado constantes revisões nas políticas de gestão de pessoas com o objetivo de adotar novas práticas de gestão, como gestão por competências e gerência participativa. Tais práticas propiciam o desenvolvimento do comprometimento organizacional, a melhoria da qualidade de vida, a redução do estresse dos colaboradores e o aumento do desenvolvimento da organização como um todo.

Nesse sentido, Dessler (1996), ao defender a formatação de políticas de gestão de pessoas capazes de incentivar e cultivar o comprometimento organizacional, menciona que o construto não é uma "cultura" misteriosa impossível de se ver, conservar ou medir. Para o autor, as organizações podem criar políticas e práticas concretas de gestão de pessoas, que irão resultar em elevado comprometimento de seus colaboradores.

Estudos como o de Demo, Martins e Roure (2013), têm se proposto a avaliar a relação existente entre as políticas de gestão de pessoas e o comprometimento organizacional. $\mathrm{O}$ estudo teve como objetivo avaliar a relação entre políticas de gestão de pessoas, comprometimento organizacional e satisfação no trabalho, com base na percepção dos colaboradores da Livraria Cultura, filial Brasília. Na referida pesquisa, os autores identificaram que duas principais políticas de gestão de pessoas foram apontadas como preditoras do comprometimento organizacional: política de envolvimento e política de recompensas, sendo a política de envolvimento a melhor preditora do comprometimento afetivo, e a política de recompensas influenciou de maneira mais significativa o comprometimento instrumental ou calculativo.

Demo et al. (2013) realizaram, ainda, um estudo confirmatório, por meio de regressão hierárquica, utilizando-se como comparação o estudo de Borges et al. (2006). No referido estudo, Borges et al. (2006) também se propuseram investigar as relações entre as três variáveis (políticas de gestão de pessoas, comprometimento organizacional e satisfação no trabalho), utilizando medidas diferentes das utilizadas por Demo et al. (2013), e chegaram a conclusão de que as políticas de gestão de pessoas são preditoras do comprometimento organizacional e da satisfação no trabalho. Demo et al. (2013) confirmaram os resultados encontrados pelos referidos autores, conforme apresentado na Tabela 1. 
Tabela 1. Resultados da Regressão Hierárquica (políticas de gestão de pessoas e comprometimento organizacional)

\begin{tabular}{ccc}
\hline Variável & $\mathbf{R}^{2}$ (Demo et al., 2013) & $\mathbf{R}^{2}$ (Borges et al., 2006) \\
\hline Comprometimento Organizacional & $0.52 * *$ ou $52 \%$ & $0.26 *$ ou $26 \%$ \\
\hline
\end{tabular}

Nota: ${ }^{*} \mathrm{p}<0.05 \mathrm{e}^{* *} \mathrm{p}<0.001$

Fonte: adaptado de Demo et al. (2013)

Ao final do estudo, Demo et al. (2013) afirmam que a política de condições de trabalho foi a mais percebida pelos colaboradores da empresa pesquisada, ou seja, há uma maior percepção por parte dos colaboradores quanto aos esforços da organização no sentido de promover a saúde, segurança e bem-estar no trabalho. No entanto, as demais políticas de gestão de pessoas (envolvimento; treinamento, desenvolvimento e educação e recompensas) foram pouco percebidas pelos colaboradores. Isso se dá talvez, segundo os autores, em virtude de deficiências na comunicação organizacional em relação às três políticas mencionadas, o que poderá resultar no não atingimento dos objetivos organizacionais.

Já Ventura (2012), ao investigar as percepções de docentes do ensino superior acerca dos construtos gestão estratégica de pessoas e comprometimento organizacional em uma Instituição de Ensino Superior, verificou que a gestão estratégica de pessoas - investigada pelos conceitos de treinamento e desenvolvimento, remuneração, incentivos e recompensas e promoção e carreira - aparece como influenciadora do comprometimento organizacional nas dimensões afetiva e normativa, enquanto que, na dimensão instrumental, há poucas associações, possivelmente relativas às condições de remuneração básica e coerente com as ofertas do mercado.

Dessa forma, Ventura (2012) aponta que pode haver uma relação entre gestão estratégica de pessoas e o comprometimento organizacional quando as políticas de gestão de pessoas são percebidas pelos colaboradores, sugerindo, assim, investimentos em estratégias de comprometimento capazes de alcançar a comunicação e o relacionamento interpessoal, bem como garantir a participação dos colaboradores nos planos estratégicos da organização.

Outra pesquisa que buscou relacionar as políticas de gestão de pessoas, incluindo a gestão do conhecimento, e o comprometimento organizacional, utilizando o modelo tridimensional de Meyer e Allen (1991), foi a de Cançado, Moraes e Silva (2006), realizada em uma empresa de operação logística do estado de Minas Gerais, denominada de XSA, que constatou, ao final da pesquisa, que o relacionamento entre as escalas de comprometimento organizacional demonstrou que a maioria das políticas de gestão de pessoas (cinco das oito avaliadas) influenciou as dimensões dos comprometimentos afetivo e normativo, o que 
possibilita afirmar que existe uma relação linear positiva entre as variáveis analisadas. As políticas de gestão de pessoas avaliadas no referido estudo foram: gestão do conhecimento, relacionamento, remuneração, treinamento e desenvolvimento, carreira, segurança no trabalho, comunicação e recrutamento e seleção, e as que tiveram influência nas dimensões afetiva e normativa do comprometimento organizacional foram: gestão do conhecimento, remuneração, treinamento e desenvolvimento, relacionamento e carreira.

O estudo de Facchini (2007) corrobora esses achados ao explicar como a percepção de políticas de gestão de pessoas influencia o comprometimento e o desempenho organizacional. A pesquisa foi realizada num grupo industrial paulista, utilizando a modelagem por equações estruturais para testar as relações entre os três construtos, e constatou que as análises das relações permitiram concluir que o investimento em políticas de gestão de pessoas influencia o comprometimento organizacional e este influencia o desempenho organizacional. A autora complementa dizendo que a comprovação da força destas relações constitui-se na principal contribuição do estudo, uma vez que poderá servir no estabelecimento de prioridades de investimentos na área de gestão de pessoas, bem como na identificação de oportunidades de implantação de novas iniciativas.

Os estudos apresentados na presente pesquisa mostram que há relações significativas entre as variáveis constituintes dos construtos. Dessa forma, pode-se elaborar a seguinte hipótese e modelo teórico da pesquisa:

H1: Políticas e práticas de gestão de pessoas tem efeitos significativos e positivos sobre o comprometimento organizacional.

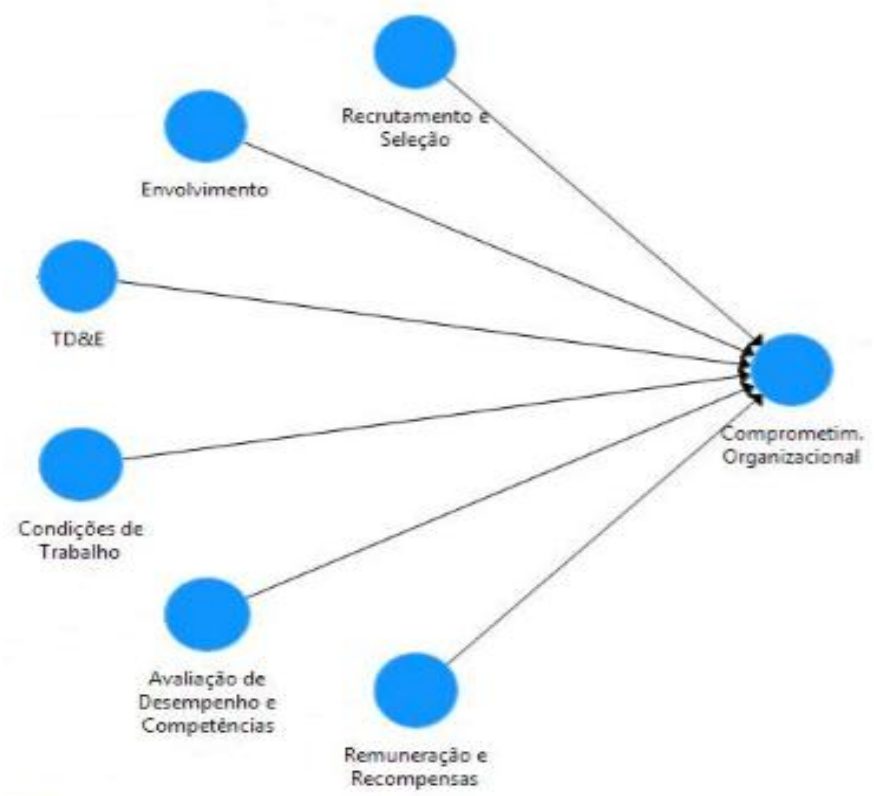

Figura 11. Modelo teórico da pesquisa

Fonte: elaborado pela autora 
Após a discussão dos principais conceitos envolvidos no presente estudo, passa-se, a seguir, a descrever o método que foi utilizado para desenvolver a presente pesquisa. 


\section{MÉTODO}

A seguir serão apresentadas as características da presente pesquisa e descritas suas etapas, incluindo os instrumentos e procedimentos para coleta de dados, descrição da população e da amostra, e os métodos utilizados no tratamento e análise dos dados.

\subsection{Caracterização Geral da Pesquisa}

A presente pesquisa pode ser classificada de caráter descritivo e explicativo, realizada por meio de levantamento (survey), adotando-se um corte transversal, com abordagem quantitativa (Vergara, 2009).

A organização pesquisada foi o Ministério do Meio Ambiente (MMA), com sede em Brasília/DF. O MMA é um órgão integrante da administração pública federal direta do Poder Executivo Federal, foi criado com a denominação de Ministério do Desenvolvimento Urbano e do Meio Ambiente, em 15 de março de 1985, após passar por algumas alterações na sua denominação e estrutura, passou a ser denominado Ministério do Meio Ambiente (MMA), em 1999. As atribuições do MMA estão previstas no Decreto $n^{\circ} 6.101$ (2007), que trata da estrutura regimental do órgão e do quadro demonstrativo de cargos em comissão e funções gratificadas. Dentre suas áreas de competência, destacam-se a política nacional do meio ambiente e dos recursos hídricos e a política de preservação, conservação e utilização sustentável de ecossistemas, e biodiversidade e florestas.

Os servidores efetivos do MMA integram a Carreira de Especialista em Meio Ambiente (CEMA), criada por meio da Lei no 10.410 (2002), ou o Plano Especial de Cargos do MMA e do Instituto Brasileiro do Meio Ambiente e dos Recursos Naturais Renováveis IBAMA (PECMA), criado por meio da Lei n ${ }^{\circ} 11.357$ (2006).

A escolha desse órgão para realização da pesquisa se deu em virtude de dois aspectos: i) facilidade de acesso aos servidores e aos dados da organização, em face do vínculo existente entre a organização e a pesquisadora; e ii) peculiaridade do contexto organizacional, por se tratar de um órgão público e pelo fato de que não foram encontrados estudos que relacionem políticas de gestão de pessoas e comprometimento organizacional em órgãos da administração direta federal.

Nesse sentido, inicialmente, realizou-se um levantamento bibliográfico e uma pesquisa documental, para a construção da fundamentação teórica pertinente à questão da pesquisa e aos objetivos propostos, e para conhecer a estrutura do MMA e as políticas de gestão de pessoas atualmente vigentes. A partir desse estudo preliminar, foram identificadas as 
seguintes variáveis que serão estudadas: políticas e práticas de gestão de pessoas e comprometimento organizacional.

\subsection{Instrumentos de Coleta de Dados}

Como instrumentos de coleta de dados, foram aplicadas duas escalas recém revisadas e validadas: Escala de Políticas e Práticas de Recursos Humanos (EPPRH) (Demo et al., 2014) e Escala de Intenções Comportamentais de Comprometimento Organizacional (EICCO) (Menezes \& Bastos, 2010), com objetivo de verificar os efeitos de políticas e práticas de gestão de pessoas sobre o comprometimento organizacional dos servidores do MMA. Adicionalmente aos itens das duas escalas, foram investigadas características pessoais e profissionais, tais como: sexo, idade, escolaridade, carreira, tempo de serviço no órgão, unidade de lotação, dentre outras.

\subsubsection{Descrição da Escala de Políticas e Práticas de Recursos Humanos (EPPRH)}

A Escala de Políticas e Práticas de Recursos Humanos (EPPRH) foi desenvolvida e validada para suprir uma lacuna na literatura e aprimorar a abrangência da Escala de Percepção de Políticas de Gestão de Pessoas (EPPGP) (Demo, 2008), incluindo as políticas de recrutamento e seleção e de avaliação de desempenho e competências. O objetivo da EPPRH é aferir a percepção dos colaboradores quanto às políticas e práticas de recursos humanos da organização.

A escala possui 40 itens em sua versão completa, e 32 na versão reduzida, sendo esta última utilizada na presente pesquisa. A EPPRH é composta por 6 (seis) fatores: recrutamento e seleção; envolvimento; treinamento, desenvolvimento e educação (TD\&E); condições de trabalho; avaliação de desempenho e competências e remuneração e recompensas, conforme demonstrado na Figura 11. Os resultados do índice de confiabilidade do estudo original (rho de Jöreskog) foram satisfatórios, pois foram superiores a 0,70 , variando entre 0,80 a 0,92 para os seis fatores (Demo et al., 2014). 


\begin{tabular}{|c|c|c|c|}
\hline Fatores & Definição Constitutiva & Itens & Total \\
\hline 1. Recrutamento e Seleção & $\begin{array}{l}\text { Proposta articulada da organização, com } \\
\text { construções teóricas e práticas, para procurar } \\
\text { colaboradores, estimulá-los a se candidatar e } \\
\text { selecioná-los, buscando harmonizar valores, } \\
\text { interesses, expectativas e competências das } \\
\text { pessoas com as características e demandas do } \\
\text { cargo e da organização. }\end{array}$ & $\begin{array}{c}1,2,3,4,5 \mathrm{e} \\
6\end{array}$ & 6 \\
\hline 2. Envolvimento & $\begin{array}{l}\text { Proposta articulada da organização, com } \\
\text { construções teóricas e práticas, para criar um } \\
\text { vínculo afetivo com seus colaboradores, } \\
\text { contribuindo para seu bem estar, em termos de } \\
\text { reconhecimento, relacionamento, participação e } \\
\text { comunicação. }\end{array}$ & $\mid \begin{array}{c}7,8,9,10,11 \\
12,13,14 \mathrm{e} \\
15\end{array}$ & 9 \\
\hline $\begin{array}{l}\text { 3. Treinamento, Desenvolvimento } \\
\text { e Educação-TD\&E }\end{array}$ & $\begin{array}{l}\text { Proposta articulada da organização, com } \\
\text { construções teóricas e práticas, para prover aos } \\
\text { colaboradores a aquisição sistemática de } \\
\text { competências e estimular a contínua } \\
\text { aprendizagem e produção de conhecimento. }\end{array}$ & 16,17 e 18 & 3 \\
\hline 4. Condições de Trabalho & $\begin{array}{l}\text { Proposta articulada da organização, com } \\
\text { construções teóricas e práticas, para prover aos } \\
\text { colaboradores boas condições de trabalho em } \\
\text { termos de beneficios, saúde, segurança e } \\
\text { tecnologia. }\end{array}$ & $\begin{array}{c}19,20,21,22 \\
\text { e } 23\end{array}$ & 5 \\
\hline $\begin{array}{l}\text { 5. Avaliação de Desempenho e } \\
\text { Competências }\end{array}$ & $\begin{array}{l}\text { Proposta articulada da organização, com } \\
\text { construções teóricas e práticas, para avaliar o } \\
\text { desempenho e as competências dos } \\
\text { colaboradores, subsidiando as decisões sobre } \\
\text { promoções, planejamento de carreira e } \\
\text { desenvolvimento. }\end{array}$ & $\begin{array}{c}24,25,26,27 \\
\text { e } 28\end{array}$ & 5 \\
\hline 6. Remuneração e Recompensas & $\begin{array}{l}\text { Proposta articulada da organização, com } \\
\text { construções teóricas e práticas, para } \\
\text { recompensar o desempenho e as competências } \\
\text { dos colaboradores em termos } \\
\text { de remuneração e incentivos. }\end{array}$ & $\begin{array}{c}29,30,31 \mathrm{e} \\
32\end{array}$ & 4 \\
\hline \multicolumn{3}{|c|}{ Total de itens } & 32 \\
\hline
\end{tabular}

Figura 12. Definição e composição dos fatores da EPPRH

Fonte: elaborado pela autora a partir de Demo et al. (2011)

Demo (2008) sugere que a referida escala, ou cada uma de suas 4 subescalas, também pode ser utilizada em futuros estudos das áreas de comportamento organizacional e afins, incrementando a produção de conhecimento científico, uma vez que a variável "percepção de políticas de gestão de pessoas" pode ser introduzida em pesquisas relacionais, como, por exemplo, a que está sendo proposta.

A escala foi adaptada à realidade do MMA, em virtude da necessidade de adequação de alguns termos face à organização e ao público estudado. Foram modificados os itens 22 (alteração do termo "na empresa" para "no órgão"), 25 (alteração do termo "salário" para "remuneração"), 30 (alteração do termo "funções comissionadas" para "cargos comissionados" e retirada do termo "bônus") e 31 (alteração do termo "Na definição de seu sistema de recompensas" para "Nas negociações que envolvem reestruturação da carreira"). 
Após as adaptações, foi realizada a validação semântica da escala, com 5 (cinco) servidores, com objetivo de verificar se os termos empregados eram de fácil compreensão.

\subsubsection{Descrição da Escala de Intenções Comportamentais de Comprometimento} Organizacional (EICCO)

A abordagem comportamental do comprometimento fundamenta a construção de escalas comportamentais em grande parte no conhecimento das consequências do envolvimento do indivíduo com sua organização, assim como nos indicadores observáveis que permitam avaliar objetivamente posturas mais ou menos comprometidas. A partir desta perspectiva, foi elaborada a Escala de Intenções Comportamentais de Comprometimento Organizacional (EICCO) (Menezes, 2006), escala que mensura o elemento "intenções comportamentais" como uma característica que entremeia as atitudes e o comportamento comprometido (Menezes \& Bastos, 2010).

A EICCO foi construída tendo em vista três problemas centrais encontrados nas medidas sobre comprometimento organizacional: o domínio da abordagem atitudinal, a pouca atenção dos pesquisadores à abordagem comportamental e a demanda por integrar tais perspectivas. Desde o trabalho clássico de Mowday et al. (1982), a integração entre as abordagens atitudinal e comportamental já tinha sido sugerida, porém nenhum estudo, antes da pesquisa de Menezes (2006), buscou atender tal proposta (Menezes, 2009). Dessa forma, a EICCO mensura o comprometimento organizacional em relação à base afetiva e o foco na organização, contemplando as abordagens atitudinal e comportamental (Menezes, 2006).

De acordo com Menezes e Bastos (2010), a versão atual da EICCO é composta por 20 itens, seguindo um modelo de escala do tipo diferencial semântico de 7 pontos, e toma o elemento "intenções comportamentais" como um elo que intermedia a relação entre atitudes (sentimentos), crenças (cognições) e o comportamento comprometido propriamente dito. Para tanto, são expostas ao sujeito situações-dilema, com cursos alternativos de ação, em que a demonstração de uma postura proativa indica comprometimento com a organização.

Os resultados de validação da EICCO apontaram que, embora haja facetas que fazem parte da constituição das intenções comportamentais de comprometimento organizacional (participação, melhor desempenho e produtividade, sacrifício extra e defesa da organização), conforme descritos na Figura 12, a constituição teórica do construto é mais bem explicada a partir de um modelo unidimensional. Em todos os itens da escala há um claro sentido semântico relacionado às ações do trabalhador para com a assunção de condutas que estejam 
além das suas obrigações diárias e atribuições do cargo. Dessa forma, a perspectiva da "proatividade" é transversal a todas as facetas da EICCO, justificando seu modelo unidimensional. O resultado da consistência interna do estudo original da EICCO (alpha de Cronbach) foi satisfatório, pois foi superior a 0,70 (Hair, Anderson, Tatham \& Black, 2009), atingindo o valor de 0,789 .

\begin{tabular}{|l|l|}
\hline \multicolumn{1}{|c|}{ Facetas } & \multicolumn{1}{c|}{ Definição } \\
\hline 1. Participação & $\begin{array}{l}\text { Refere-se à intenção dos funcionários em participar das atividades, políticas e } \\
\text { programas da organização a qual fazem parte, de modo a identificar problemas e } \\
\text { pontos fracos, bem como formecer sugestões e resoluções para estes. }\end{array}$ \\
\hline $\begin{array}{l}\text { 2. Melhor desempenho e e } \\
\text { produtividade }\end{array}$ & $\begin{array}{l}\text { Corresponde ao aumento donível de desempenho e produtividade do funcionário } \\
\text { mediante solicitação da organização, bem como sua capacidade de reavaliar as } \\
\text { formas de trabalho, modificando-as. }\end{array}$ \\
\hline $\begin{array}{l}\text { 3. Empenho extra ou sacrificio } \\
\text { adicional }\end{array}$ & $\begin{array}{l}\text { Corresponde à dedicação e empenho extra dos funcionários em prol da organização, } \\
\text { como respostas às necessidades emergenciais da empresa/órgão, bem como a } \\
\text { abdicação temporária, ou até mesmo permanente, de benefícios e vantagens. }\end{array}$ \\
\hline 4. Defesa da organização & $\begin{array}{l}\text { Diz respeito à disposição em defender a organização frente às críticas alheias, } \\
\text { exibindo preocupação com a sua imagem interna e externa. }\end{array}$ \\
\hline
\end{tabular}

Figura 13. Definições das facetas da EICCO

Fonte: elaborado pela autora a partir de Menezes e Bastos (2010)

Assim como a EPPRH, a EICCO foi adaptada à realidade do MMA, em virtude da necessidade de adequação de alguns termos face à organização e ao público estudado. Foram modificados os itens 6 e 8 (alteração do termo "ela" para "sua chefia"), 10 (alteração do termo "teve de fazer uma redução no quadro de pessoal" para "está com o quadro de pessoal reduzido" e alteração do termo "a manutenção do nível de produtividade" para "a necessidade de atingimento das metas"), 17 (alteração do termo "pela empresa" para "pelo órgão" e "maior concorrente" para "outros órgãos") e 18 (retirada do termo "e produtividade"). Após as adaptações, foi realizada a validação semântica da escala, com 5 (cinco) servidores, com objetivo de verificar se os termos empregados eram de fácil compreensão.

\subsection{Procedimentos de coleta de dados}

Inicialmente, foi solicitada autorização ao Coordenador-Geral de Gestão de Pessoas do MMA para realização da pesquisa, e apoio da Assessoria de Comunicação Social do MMA para divulgação da pesquisa. A coleta de dados primários da pesquisa foi realizada mediante a utilização de um questionário on-line, por meio do Survey Monkey. O link do questionário foi enviado ao e-mail institucional dos servidores que foram selecionados para compor a população desta pesquisa.

No início do questionário on-line, continha o convite para participar da pesquisa, esclarecendo sobre o objetivo do estudo, tempo estimado para resposta e, principalmente, quanto ao sigilo absoluto das respostas individuais. Foi salientado que se tratava de uma 
pesquisa de cunho acadêmico. Para iniciar o questionário, o sujeito deveria firmar o termo de consentimento, confirmando que leu as informações constantes no convite e que sua participação era voluntária. Não houve necessidade de identificação na pesquisa, preservandose, assim, a identidade dos respondentes.

A etapa de coleta de dados foi realizada no período de 24/02 a 30/03/2015, correspondendo a trinta e cinco dias. Foram recebidos 243 instrumentos válidos, que representam aproximadamente $28,22 \%$ da população do presente estudo. Assim, os dados foram importados do Survey Monkey para uma planilha do Microsoft Excel, para serem adequadamente preparados para utilização nos softwares de análises estatísticas.

\subsection{População e amostra}

O quadro de pessoal do MMA, em fevereiro/2015, era composto por 1.186 servidores, conforme consulta realizada no Sistema Integrado de Administração de Recursos Humanos (SIAPE). Compuseram a população desta pesquisa os servidores das seguintes situações funcionais: ativo permanente (ocupante de cargo efetivo), requisitado (ocupante de cargo efetivo em outro órgão e ocupa cargo em comissão no MMA) e exercício descentralizado de carreira (ocupante de cargo efetivo em outro órgão e encontra-se em exercício no MMA), que totalizaram 863 servidores, conforme destacado na tabela abaixo:

Tabela 2. Quantitativo de servidores do MMA, por situação funcional e gênero

\begin{tabular}{lccc}
\hline \multirow{2}{*}{ Situação Funcional } & \multicolumn{2}{c}{ Qtd. de Servidores } & \multirow{2}{*}{ Subtotal } \\
\cline { 2 - 3 } & Masc & Fem & \\
Ativo Permanente & 360 & 368 & \multirow{2}{*}{$\mathbf{8 6 3}$} \\
Requisitado & 50 & 34 & \\
Exercício Descentralizado de Carreira & 35 & 16 & \\
Nomeado para cargo em comissão & 30 & 39 & \\
Estagiário & 37 & 72 & \\
Aposentado & 30 & 19 & \multirow{2}{*}{323} \\
Cedido & 32 & 27 & \\
Contrato Temporário & 16 & 21 & \\
\hline \multicolumn{1}{c}{ Total Geral } & $\mathbf{5 9 0}$ & $\mathbf{5 9 6}$ & $\mathbf{1 . 1 8 6}$ \\
\hline
\end{tabular}

Fonte: SIAPE - fevereiro/2015

Dessa forma, não integraram a população da pesquisa, os aposentados e os servidores cedidos a outros órgãos, por não fazerem parte da força de trabalho da instituição, bem como os nomeados para cargo em comissão (sem vínculo efetivo com o serviço público), os contratos temporários, os estagiários e os prestadores de serviços terceirizados, em virtude do caráter precário de nomeação ou contratação.

A amostra foi caracterizada como não probabilística ou por conveniência, uma vez que dependeu da disponibilidade e aceitação dos servidores em participar da pesquisa. Cohen 
(1992) alerta que para se utilizar técnicas de análise multivariada é importante selecionar uma amostra mínima que tenha poder estatístico maior que 0,80 . Por meio do software GPower, versão 3.1, e considerando dentre as variáveis preditoras a que possuía maior número de fatores, no caso, políticas e práticas de gestão de pessoas (seis fatores), obteve-se a amostra mínima, com $\alpha=0,05$, ES médio e 6 preditores, de 146 sujeitos.

$\mathrm{Na}$ visão de Hair et al. (2009), quando for utilizada a Modelagem por Equações Estruturais (MEE), o tamanho da amostra deve ser proporcional à complexidade do modelo. Os autores sugerem que se tenha ao menos 10 respondentes por parâmetro especificado. $\mathrm{O}$ modelo da MEE da presente pesquisa possui 7 parâmetros especificados, necessitando de uma amostra mínima de 70 participantes. Dessa forma, observa-se que a amostra final atende ao valor encontrado no software Gpower e o que foi proposto por Hair et al. (2009).

Para descrição da amostra, os dados foram importados para o software Statistical Package for the Social Sciences - SPSS, versão 17.0. O tamanho da amostra final foi de 243 respondentes. A tabela abaixo apresenta as distribuições de frequências das variáveis sociodemográficas da amostra:

Tabela 3. Caracterização da amostra por variáveis sociodemográficas

\begin{tabular}{lcccccc}
\hline \multicolumn{1}{c}{ Variáveis } & \multicolumn{2}{c}{$\begin{array}{c}\text { Masculino } \\
(\mathbf{n = 1 1 5})\end{array}$} & \multicolumn{2}{c}{$\begin{array}{c}\text { Feminino } \\
(\mathbf{n = 1 2 4})\end{array}$} & \multicolumn{2}{c}{$\begin{array}{c}\text { Total } \\
(\mathbf{n = 2 3 9})\end{array}$} \\
\cline { 2 - 7 } & $\mathbf{F}$ & $\mathbf{\%}$ & $\mathbf{F}$ & $\mathbf{\%}$ & $\mathbf{F}$ & $\mathbf{\%}$ \\
\hline Idade & & & & & & \\
De 21 a 30 anos & 30 & 26,1 & 37 & 29,8 & 67 & 28,0 \\
De 31 a 40 anos & 39 & 33,9 & 51 & 41,1 & 90 & 37,7 \\
De 41 a 50 anos & 24 & 20,9 & 16 & 12,9 & 40 & 16,7 \\
De 51 a 60 anos & 20 & 17,4 & 18 & 14,5 & 38 & 15,9 \\
Acima de 60 anos & 2 & 1,7 & 2 & 1,6 & 4 & 1,7 \\
Escolaridade & & & & & & \\
Ensino fundamental completo & 0 & 0 & 1 & 0,8 & 1 & 0,4 \\
Ensino médio incompleto & 0 & 0 & 0 & 0 & 0 & 0 \\
Ensino médio completo & 4 & 3,5 & 1 & 0,8 & 5 & 2,1 \\
Ensino Superior incompleto & 2 & 1,7 & 2 & 1,6 & 4 & 1,7 \\
Ensino Superior completo & 34 & 29,6 & 37 & 29,8 & 71 & 29,7 \\
Pós-graduação lato sensu & 43 & 37,4 & 47 & 37,9 & 90 & 37,7 \\
(Especialização/MBA) & 25 & 21,7 & 32 & 25,8 & 57 & 23,8 \\
Mestrado & 7 & 6,1 & 4 & 3,2 & 11 & 4,6 \\
Doutorado ou Pós-doutorado & 73
\end{tabular}

Nota: 4 casos omissos em todos os dados sociodemográficos e profissionais

Fonte: Dados da pesquisa

Em relação à amostra investigada, verifica-se que a maioria dos respondentes encontra-se nas faixas etária de 21 a 30 anos (28\%) e de 31 a 40 anos de idade (37,7\%), representando mais de $65 \%$ da amostra pesquisada. Quanto ao gênero, a amostra foi composta por 115 sujeitos do sexo masculino e 124 do sexo feminino, o que demonstra um equilíbrio de 
gênero dos participantes, se coadunando com o perfil do quadro de pessoal do MMA, que no mês de fevereiro/2015 era de 590 homens e 596 mulheres. Do total da amostra (243), 4 respondentes não responderam nenhum dos itens sociodemográficos e profissionais, outros 8 deixaram de responder alguns dos itens. Outra informação verificada foi que nenhum dos respondentes tinha idade entre 18 e 20 anos e escolaridade inferior a ensino fundamental completo.

Em relação à escolaridade, nota-se que a maior parte da amostra tem escolaridade elevada, sendo a maior frequência na formação em nível de pós-graduação lato sensu especialização/MBA (37,7\%), seguida do ensino superior completo (29,7\%). Outra escolaridade que demonstrou uma frequência representativa foi a de mestrado $(23,8 \%)$.

Constatou-se também, conforme demonstrado na figura abaixo, que a maioria dos respondentes pertence ou à Carreira de Especialista em Meio Ambiente (CEMA) (75\%) ou ao Plano Especial de Cargos do MMA e do IBAMA (PECMA) (17\%), ou seja, 92\% da amostra pertencem ao quadro efetivo do MMA.

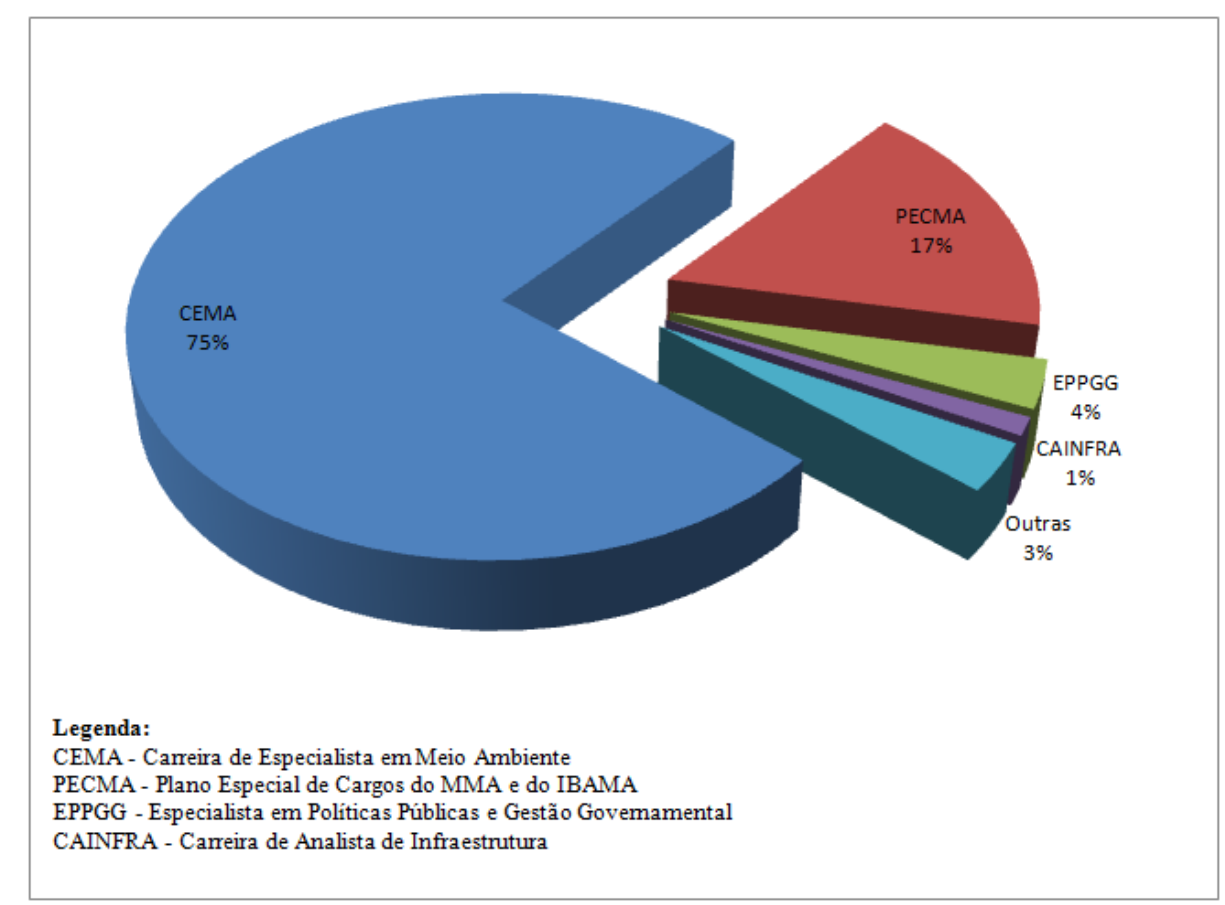

Figura 14. Distribuição de frequência da amostra por Carreira

Fonte: Dados da pesquisa

Ao analisar o tempo de serviço na organização, verificou-se que $80 \%$ dos servidores investigados possui tempo de serviço no órgão entre 1 a 13 anos, conforme se observa na Figura 14, refletindo a realidade da população estudada, uma vez que o primeiro concurso público realizado para provimento de cargo efetivo foi em 2004, ou seja, há 11 anos. Os 
servidores que ingressaram no órgão antes dessa data são os que foram redistribuídos de outros órgãos, principalmente do IBAMA, para o MMA, quando da criação do órgão.

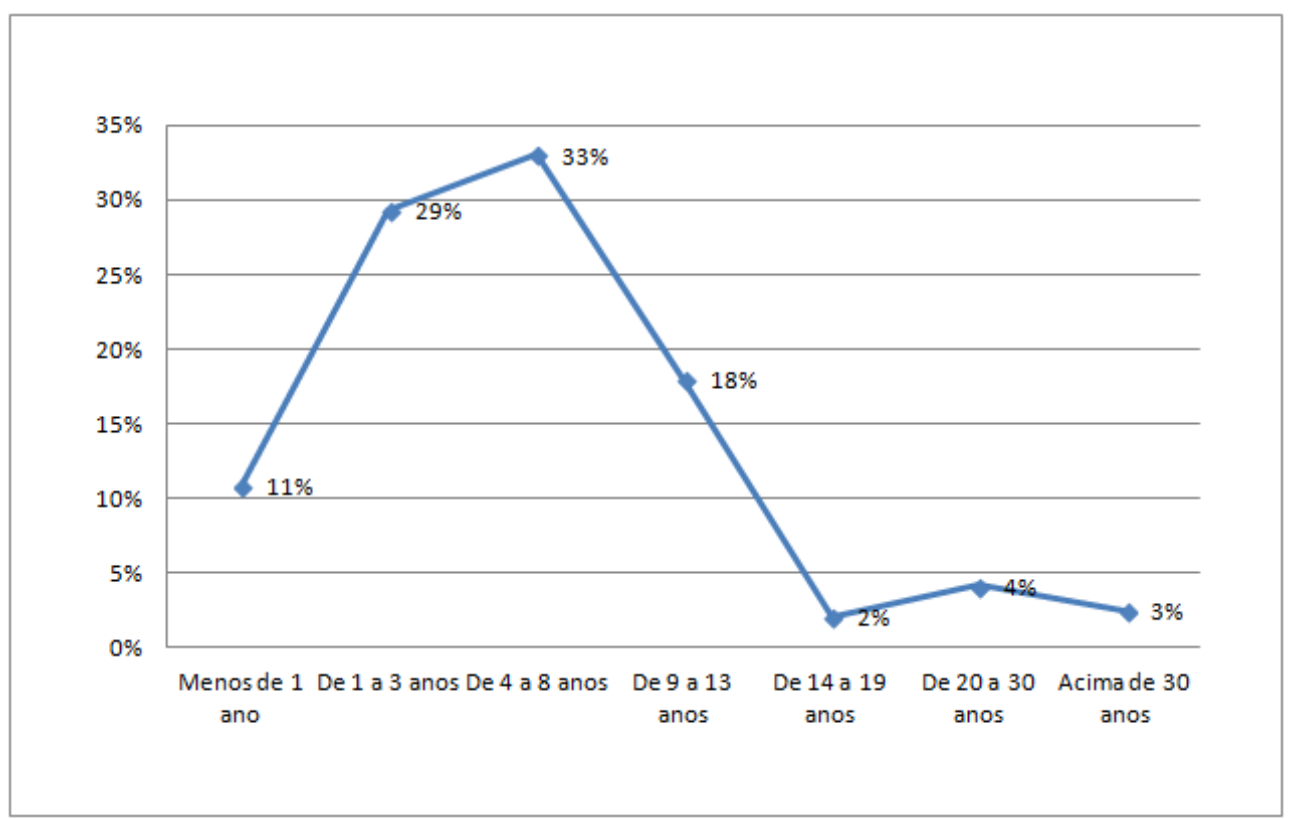

Figura 15. Distribuição de frequência da amostra por tempo de serviço no MMA

Fonte: Dados da pesquisa

Ao serem questionados sobre a participação em algum dos programas de incentivos oferecidos pelo MMA para realização de cursos de graduação, pós-graduação e língua estrangeira, na forma de subsídio financeiro, 50,2\% dos respondentes afirmaram que participam ou já participaram de algum dos programas, conforme dados apresentados na Tabela 4.

Tabela 4. Distribuição de frequência dos demais dados profissionais

\begin{tabular}{ccccccc}
\hline \multirow{2}{*}{ Variáveis } & \multicolumn{2}{c}{$\begin{array}{c}\text { Masculino } \\
(\mathbf{n}=115)\end{array}$} & \multicolumn{2}{c}{$\begin{array}{c}\text { Feminino } \\
(\mathbf{n}=124)\end{array}$} & \multicolumn{2}{c}{$\begin{array}{c}\text { Total } \\
(\mathbf{n}=239) *\end{array}$} \\
\cline { 2 - 7 } & $\mathbf{F}$ & $\%$ & F & $\%$ & F & $\%$ \\
\hline
\end{tabular}

Participa ou já participou de algum programa de incentivo (graduação, pós-graduação ou língua estrangeira)

\begin{tabular}{lcccccc} 
Sim & 56 & 48,7 & 64 & 51,6 & 120 & 50,2 \\
Não & 58 & 50,4 & 59 & 47,6 & 117 & 49,0 \\
Casos omissos & 1 & 0,9 & 1 & 0,8 & 2 & 0,8 \\
\multicolumn{1}{l}{ Ocupa cargo em comissão } & & & & & & \\
Sim & 29 & 25,2 & 30 & 24,2 & 59 & 24,7 \\
Não & 85 & 73,9 & 89 & 71,8 & 174 & 72,8 \\
Casos omissos & 1 & 0,9 & 5 & 4,0 & 6 & 2,5 \\
\hline
\end{tabular}

Nota: 4 casos omissos em todos os dados sociodemográficos e profissionais

Fonte: Dados da pesquisa 
Constatou-se ainda que apenas 24,7\% dos respondentes ocupam cargo em comissão. Ao realizar o cruzamento das variáveis escolaridade e exercício de cargo em comissão, verifica-se que os servidores com maior escolaridade - considerando pós-graduação lato sensu, mestrado, doutorado e pós-doutorado - representam o maior percentual de ocupantes de cargos em comissão (69\%), indicando uma tendência de valorização dos servidores com maior qualificação no exercício de cargos de chefia ou assessoramento.

\subsection{Procedimentos de tratamento e análise dos dados}

Para o tratamento dos dados coletados foram utilizados os softwares SPSS, versão 17.0, e o RStudio, versão 0.98.1103. Inicialmente foi realizada uma análise exploratória e de preparação para a análise multivariada, conforme recomendado por Hair et al. (2009). Essa etapa consistiu em uma análise de normalidade, assimetria, curtose, missing values (dados faltantes) e outliers (valores extremos). A denominada "análise multivariada" corresponde a um grande número de métodos e técnicas que utilizam, simultaneamente, todas as variáveis na interpretação teórica do conjunto de dados obtidos (Moita Neto, 2004).

Para a análise da normalidade multivariada dos dados da EPPRH e da EICCO, por meio da assimetria e curtose, foi realizado o teste de Mardia, no RStudio. Em complementação, foram realizados ainda os testes de Henze-Zirkler e Royston. Os resultados dos testes demonstraram a não normalidade multivariada dos dados. Em seguida, foi utilizada a função uninorm do RStudio com objetivo de verificar se havia normalidade univariada e, em caso afirmativo, tentar entender a não normalidade multivariada. No entanto, os dados também não apresentaram normalidade univariada. Assim, optou-se em realizar a transformação dos dados.

Apesar dos dados das duas escalas (EPPRH e EICCO) não terem apresentado distribuição normal, os dados da EPPRH teve assimetria menor que 1, ou seja, próxima de uma distribuição normal. Dessa forma, optou-se por realizar a transformação apenas dos dados da EICCO. A transformação foi realizada por meio da metodologia Box-Cox (Box \& Cox, 1964), no SPSS, com objetivo de estabilizar ou reduzir a variabilidade existente dos dados e normalizar os resíduos. Em virtude do menor valor da EICCO ser um número negativo (-3), foi adicionada, a cada variável, uma constante (+4) para que os valores negativos se transformassem em um número positivo (a variável -3 se transformou em +1 ).

Osborne (2010) sugere aos pesquisadores que objetivam limpar seu banco de dados a utilização da técnica Box-Cox, uma vez que ela fornece uma gama de transformações para 
otimamente normalizar uma variável particular, eliminando a necessidade de tentar diferentes transformações aleatoriamente para escolher a melhor opção. Box e Cox (1964) conceberam originalmente essa transformação como uma panaceia para corrigir simultaneamente a normalidade, linearidade, e homocedasticidade dos dados (Osborne, 2010).

No entanto, Osborne (2002) orienta que as transformações de dados devem ser utilizadas com cuidado, e nunca a menos que haja uma razão clara, uma vez que elas podem alterar a natureza fundamental dos dados, tais como a mudança da escala de medição de intervalo ou a razão para ordinal, e criar relações curvilíneas, o que tornaria a interpretação mais complexa. Por ouro lado, existem muitas razões válidas para a utilização das transformações de dados, incluindo a melhoria da normalidade, estabilização da variância, conversão de escalas para medição intervalar. $O$ autor acrescenta, ainda, que os pesquisadores, ao utilizar as transformações, devem garantir a ancoragem da variável em um lugar onde a transformação terá o efeito ótimo, no caso da raiz quadrada, log e inversa, o ponto de ancoragem deve ser 1,0.

Após realizada a transformação dos dados da EICCO, os testes de normalidade univariada e multivariada foram refeitos e, apesar da melhora na distribuição, os dados continuaram não apresentando normalidade. Em seguida, foi realizada a análise dos missing values no SPSS, a qual não detectou dados omissos, assim como as análises dos outliers univariados e multivariados, que foram realizadas no RStudio, por meio da função uniplot e da distância Mahalanobis em $\chi^{2}(1253)=2122,590, \mathrm{p}<0,001$, respectivamente, não encontraram dados extremos. A análise de confiabilidade das escalas utilizadas no presente estudo (EPPRH e EICCO) foi realizada por meio do alpha de Cronbach (consistência interna), e os resultados são apresentados na tabela a seguir, contendo também os resultados dos estudos originais:

Tabela 5. Resultados da análise de confiabilidade das escalas

\begin{tabular}{lcc}
\hline \multicolumn{1}{c}{ Escalas } & $\begin{array}{c}\text { Alpha de Cronbach } \\
\text { encontrado }\end{array}$ & $\begin{array}{c}\text { Índice de confiabilidade } \\
\text { estudo original }\end{array}$ \\
\hline EICCO & 0,87 & $0,78^{*}$ \\
EPPRH & 0,70 a 0,91 & 0,80 a $0,92^{* *}$ \\
Fator 1 & 0,83 & 0,82 \\
Fator 2 & 0,91 & 0,92 \\
Fator 3 & 0,80 & 0,88 \\
Fator 4 & 0,70 & 0,80 \\
Fator 5 & 0,79 & 0,91 \\
Fator 6 & 0,70 & 0,86 \\
\hline
\end{tabular}

*Alpha de Cronbach **rho de Jöreskog 
Nota: ver denominação dos fatores da EPPRH na Figura 11

Fonte: Dados da Pesquisa, Demo et al. (2014) e Menezes e Bastos (2010)

A partir daí, procederam-se às análises estatísticas descritivas, para identificar a percepção quanto às políticas e práticas de gestão de pessoas e a intenção comportamental de comprometimento organizacional dos servidores com a organização, atendendo-se, assim, os dois primeiros objetivos específicos. Em seguida, foi utilizada a análise de variância (ANOVA) e o teste $t$, para amostras independentes, para a análise dos dados sociodemográficos e profissionais, com objetivo de verificar as diferenças entre as médias desses dados nas variáveis estudadas, atendendo-se ao terceiro e último objetivo específico. E por fim, adotou-se como técnica estatística multivariada a Modelagem por Equações Estruturais - MEE para verificar os efeitos de políticas e práticas da gestão de pessoas sobre o comprometimento organizacional de servidores do MMA, com objetivo de responder à pergunta de pesquisa e atender ao objetivo geral do presente estudo. As análises estatísticas descritiva, a ANOVA e o teste $\mathrm{t}$ foram realizados no SPSS e a MEE no RStudio. A seguir são relatados os procedimentos para realização da MEE.

\subsubsection{Modelagem por Equações Estruturais (MEE)}

De acordo com Ullman (2007), a Modelagem por Equações Estruturais (MEE) pode ser definida como uma coleção de técnicas estatísticas que permitem examinar, simultaneamente, uma série de relações entre variáveis dependentes e independentes, que podem ser tanto latentes ou observáveis. As variáveis latentes são medidas não diretamente observadas, ou seja, que derivam de indicadores observáveis, como, por exemplo, os itens de uma escala de comportamento organizacional (Pilati \& Laros, 2007).

A MEE é realizada com base em uma matriz empírica de covariância ou de correlação, a partir da qual é estimada a matriz de covariância ou correlação da população, com base nas relações definidas pelo pesquisador em um diagrama de caminhos, que são traduzidas em equações ou matrizes (Ullman, 2007). Dessa forma, se o modelo proposto for plausível, as covariâncias provenientes de dados amostrais poderão reproduzir os dados populacionais. Do contrário, os resíduos serão elevados (Pilati \& Laros, 2007).

Pilati e Laros (2007) definem dois pressupostos para utilização da MEE, quais sejam: a) que as medidas utilizadas pelo pesquisador tenham boa qualidade psicométrica e b) que os modelos teóricos sejam sólidos e fundamentados em pesquisas anteriores que permitam ao pesquisador definir as relações entre as variáveis com propriedade. Nesse sentido, a escolha 
da MEE, como técnica para análise dos dados da presente pesquisa, se deu pela possibilidade de examinar, simultaneamente, as relações entre as políticas e práticas de gestão de pessoas e o comprometimento organizacional dos servidores do MMA. Tais relações encontram fundamentação teórica nos estudos de Borges et al. (2006), Cançado et al. (2006), Facchini (2007), Ventura (2012) e Demo et al. (2013).

Primeiramente, uma das questões de maior importância na MEE é a especificação do modelo. Especificar o modelo consiste em indicar as relações que supostamente existem ou não entre variáveis observáveis e latentes. Para tanto, o pesquisador deve lançar mão de uma fundamentação teórica sólida, uma vez que o objetivo da MEE é a confirmação de hipóteses ou teorias (Pilati \& Laros, 2007; Weston \& Gore Jr., 2006). A especificação do modelo da MEE geralmente é realizada por meio de uma representação gráfica ou pictórica, conforme a Figura 15, que representa o modelo da presente pesquisa.

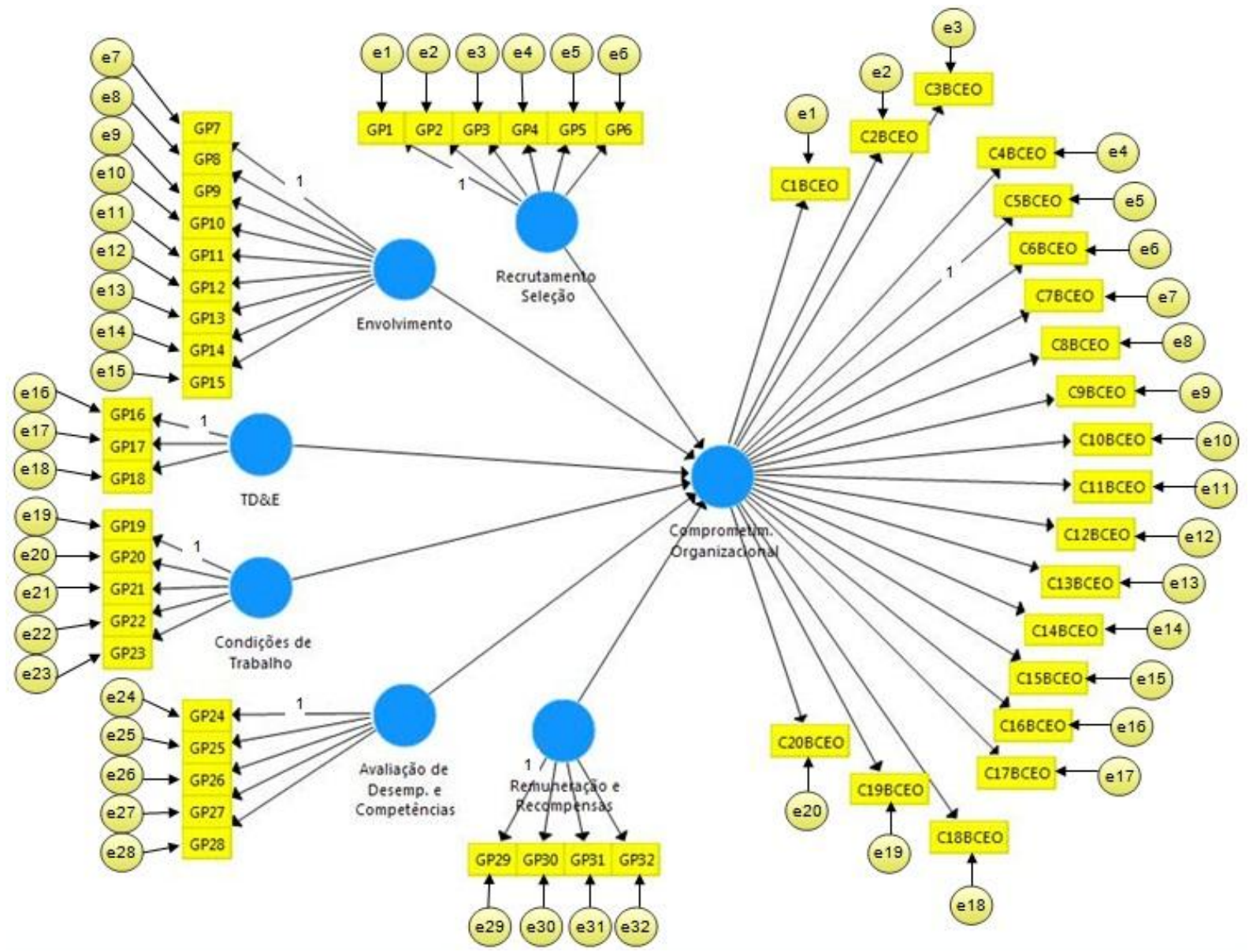

Figura 16. Especificação do modelo de pesquisa - MEE Fonte: elaborado pela autora.

Os círculos identificam as variáveis latentes do modelo, os retângulos ou quadrados indicam as variáveis observadas, e os erros associados a cada variável observada é representado pela letra "e". Dessa forma, as variáveis latentes estão vinculadas às variáveis 
observadas, uma vez que as variáveis latentes são mensuradas por fenômenos observáveis do campo de investigação. Por exemplo, os itens de uma escala são os indicadores observáveis de construtos latentes (Pilati \& Laros, 2007).

Nessa etapa de especificação do modelo, é necessário que se identifique dois submodelos existentes. O primeiro corresponde ao modelo de mensuração, que se traduz na relação entre as variáveis latentes (ver Figura 16: recrutamento e seleção; envolvimento; treinamento, desenvolvimento e educação (TD\&E); condições de trabalho; avaliação de desempenho e competências e remuneração e recompensas - que formam o construto políticas de gestão de pessoas; e o comprometimento organizacional) e as respectivas variáveis observadas (que correspondem aos itens das escalas EPPRH e EICCO). Já o segundo sub-modelo é chamado de modelo estrutural, que consiste nas relações existentes entre as variáveis latentes do modelo, ou seja, entre as seis políticas de gestão de pessoas, citadas acima, e o comprometimento organizacional (Pilati \& Laros, 2007).

As relações ou parâmetros são representados por setas direcionais ou não-direcionais. As setas retas unidirecionais podem representar relações diretas entre variáveis latentes ou observáveis (ex., a relação existente entre as variáveis "recrutamento e seleção" e “comprometimento organizacional”). Em MEE, as variáveis dependentes são também denominadas endógenas, e recebem as setas unidirecionais (ex., a variável "comprometimento organizacional"). As variáveis independentes, por sua vez, são também denominadas exógenas, de onde saem as setas unidirecionais (ex., a variável "recrutamento e seleção") (Hair et al., 2009).

As relações existentes entre as variáveis determinam se o modelo é recursivo ou nãorecursivo. O modelo recursivo é composto por relações unidirecionais, conforme representado pela Figura 16. Os modelos não-recursivos são caracterizados por relações recíprocas ou de dupla determinação, representadas por setas retas bidirecionais ou por duas setas unidirecionais entre duas variáveis (Hair et al., 2009; Pilati \& Laros, 2007).

De acordo com Weston e Gore Jr. (2006), há três formas de tratar as relações entre as variáveis de um modelo: determinar que existe relação, mas que não será estimada (nesse caso, o parâmetro será 1,0); determinar que existe relação e deixar o parâmetro livre para ser estimado; ou determinar que não existe relação e, portanto, não estimá-la. Os autores alertam que é necessário designar um indicador representativo da variável latente, utilizando-se o parâmetro 1,0, e deve ser feito para a variável observável que, segundo análises anteriores, mais bem a representa. Para os demais parâmetros deixados livres, espera-se que o modelo possa estimar as relações com base na matriz de covariância estimada. 
O objetivo da estimação é encontrar valores para os parâmetros especificados que reproduzam mais fielmente a matriz de covariância ou correlação observada (Kahn, 2006). O método a ser empregado varia conforme a matriz escolhida para pesar as diferenças entre a matriz estimada da população e a matriz da amostra. Para a escolha do método mais adequado, é importante considerar o tamanho da amostra disponível, a normalidade dos dados e a admissão de independência entre os erros estimados do modelo (Ullman, 2007).

De acordo com Foguet e Gallart (2001), são frequentemente observados na literatura especializada quatro métodos de estimação de parâmetros em MEE: a) Quadrados Mínimos Não-Ponderados (ULS); b) Quadrados Mínimos Ponderados (GLS); c) Máxima Verossimilhança (ML) e d) Método Assintótico Isento de Pressupostos de Distribuição (ADF). O método da Máxima Verossimilhança (ML) tem como objetivo estimar parâmetros que, se fossem provenientes da população real, maximizariam a probabilidade de que a matriz de covariância observada fosse proveniente dessa população (Kahn, 2006).

O ML funciona bem para amostras entre 200 a 500 indivíduos e é utilizado quando se verifica a normalidade dos dados (Pilati \& Laros, 2007). Por outro lado, Hair et al. (2009) e Weston e Gore Jr. (2006) argumentam que o ML gera resultados confiáveis diante de moderadas violações da normalidade. Rosseel (2012) corrobora esse entendimento ao afirmar que se o modelo for identificado e especificado corretamente, o ML estima os parâmetros de forma consistente. $\mathrm{Hu}$ e Bentler (1995) argumentam que o método ML deve ser preferencialmente utilizado na avaliação dos modelos, uma vez que é o método de estimação que produz melhores resultados nos diversos índices de ajustes utilizados para a avaliação na MEE.

No entanto, de acordo com Rosseel (2012), ao utilizar o ML com dados que não atingiram o pressuposto da normalidade, os erros padrão tendem a ser muito pequenos, o que poderia resultar na rejeição da hipótese nula (que um parâmetro é zero) com muita frequência. Além disso, o teste estatístico do modelo $\left(\chi^{2}\right)$ tende a ser muito grande, podendo levar à rejeição do modelo também com muita frequência. Dessa forma, muitos autores têm melhorado a metodologia ML para produzir erros padrão que são assintoticamente corretos para distribuições não normais, e onde uma estatística de teste robusto é utilizada para avaliação global do modelo. Os erros padrão dos estimadores do ML são baseados na matriz de covariância que é obtida invertendo a matriz de informação associada. Assim, erros padrão redimensionados substituem esta matriz de covariância por uma matriz de covariância do tipo sanduíche. 
Nesse sentido, o método mais conhecido para corrigir o teste estatístico do modelo $\left(\chi^{2}\right)$ é o chamado teste estatístico de Satorra-Bentler. Seu método redimensiona o valor do $\chi^{2}$ baseado no ML por um montante que reflete o grau de achatamento. Vários estudos de simulação mostraram que esta correção é eficaz com dados não normais (Chou, Bentler \& Satorra 1991; Curran, Oeste \& Finch 1996), mesmo com amostras pequenas (Rosseel, 2012). Dessa forma, na presente pesquisa adotou-se o método Máxima Verossimilhança - ML para estimação dos parâmetros do modelo, mas utilizando-se erros padrão robustos e o teste estatístico de Satorra-Bentler, em virtude da violação ao pressuposto de normalidade dos dados e do tamanho da amostra.

Após a definição dos aspectos relativos à estimação de parâmetros, se faz necessário verificar o ajuste do modelo de mensuração para que o modelo de equações estruturais possa ser testado. Esse processo de aferição do modelo de mensuração é conhecido como análise fatorial confirmatória (AFC) (Pilati \& Laros, 2007). O objetivo de avaliar o ajuste do modelo é verificar se as associações entre as variáveis observáveis e latentes do modelo estimado refletem adequadamente os dados da amostra (Weston \& Gore Jr., 2006).

Hair et al. (2009) classificam os índices de adequação em três categorias principais: a) medidas de ajuste absoluto ( $\chi 2$, NCP, SNCP, GFI, RMR, RMSEA, ECVI, CVI), que avaliam o ajuste geral do modelo (de mensuração e estrutural simultaneamente) à matriz dos dados; b) medidas de ajuste incremental (AGFI, TLI, NFI, RFI, IFI, CFI), que permitem comparar o modelo estimado a outros modelos alternativos; e c) medidas de ajuste parcimonioso (PNFI, PGFI, AIC), que pretendem diagnosticar se o ajuste é devido a um "superajustamento" dos dados aos coeficientes.

Já Ullman (2007) apresenta os índices de ajustes em cinco categorias: a) índices de ajuste comparativo (NFI, NNFI, IFI, CFI, RMSEA), que buscam comparar o modelo estimado com outros modelos independentes; b) índice de ajuste absoluto (MFI), que avalia o modelo estimado sem compará-lo com outros modelos alternativos; c) índices de proporção da variância explicada (GFI, AGFI), que consideram a proporção de variância explicada pela matriz de covariância estimada da população em relação à amostra; d) índices de parcimônia do modelo testado (PGFI, AIC, CAIC), que avaliam o quão parcimonioso é o modelo pela proporção do número de parâmetros estimados e o número de dados não redundantes na matriz de covariância; e e) índices de ajuste baseados nos resíduos ou erros (RMR, SRMR), que buscam avaliar a distância entre os parâmetros estimados do modelo e os dados da matriz de covariância ou correlação da amostra. 
Pilati \& Laros (2007) sugerem aos pesquisadores selecionar um número específico de índices de acordo com os objetivos do estudo. Dessa forma, na Figura 17, estão descritos os índices utilizados na presente pesquisa:

\begin{tabular}{|c|c|c|}
\hline Índice & Definição & Parâmetro \\
\hline Qui-quadrado $\left(\chi^{2}\right)$ & $\begin{array}{l}\text { Avalia o ajuste geral do modelo (de } \\
\text { mensuração e estrutural simultaneamente) à } \\
\text { matriz dos dados, servindo como base para } \\
\text { testar se o modelo reproduz perfeitamente as } \\
\text { relações entre as variáveis analisadas (Hair } \\
\text { et al., 2005). }\end{array}$ & $>0,05$ \\
\hline $\begin{array}{l}\text { CFI - Índice de Ajuste } \\
\text { Comparativo }\end{array}$ & $\begin{array}{l}\text { Acessa o ajusterelativo a outros índices com } \\
\text { o emprego de distribuição não-central do } \chi 2 \\
\text { com parâmetros não centrais. Apresenta } \\
\text { desempenho satisfatório também para } \\
\text { pequenas amostras. Resultados no intervalo } \\
\text { de } 0 \text { a } 1.0 \text { (Ullman, 2007). }\end{array}$ & $\begin{array}{l}\text { A partir de } \\
0,90\end{array}$ \\
\hline $\begin{array}{l}\text { RMSEA - Raiz do Erro } \\
\text { Quadrático Médio de } \\
\text { Aproximação }\end{array}$ & $\begin{array}{l}\text { Estima a lacuna de ajuste em um modelo, } \\
\text { comparando-o a um modelo perfeito } \\
\text { (Ullman, 2007). Um valor de } 0.00 \text { indica que } \\
\text { o modelo se ajusta exatamente aos dados } \\
\text { (Weston \& Gore Jr., 2006). }\end{array}$ & $<0,08$ \\
\hline $\begin{array}{l}\text { TLI ou NNFI - Índice de } \\
\text { Tucker-Lewis }\end{array}$ & $\begin{array}{l}\text { Combina uma medida de parcimônia em um } \\
\text { indice comparativo entre os modelos } \\
\text { proposto e nulo. }\end{array}$ & $\begin{array}{l}\text { A partir de } \\
0,90\end{array}$ \\
\hline $\begin{array}{l}\text { AIC - Critério de } \\
\text { Informação de Akaike }\end{array}$ & $\begin{array}{l}\text { Utilizado na comparação de modelos } \\
\text { concorrentes, é considerado indice preditivo } \\
\text { de generalização da amostra para a } \\
\text { população (Weston \& Gore Jr., 2006). Pilati } \\
\text { e Laros (2007) alertam que é importante } \\
\text { considerar os graus de liberdade dos } \\
\text { modelos para a análise desse índice (relação } \\
\text { entre o valor do indice e o número de } \\
\text { parâmetros do modelo). }\end{array}$ & $\begin{array}{l}\text { Valores } \\
\text { positivos } \\
\text { menores }\end{array}$ \\
\hline $\begin{array}{c}\text { BIC - Critério de } \\
\text { Informação Bayesiano de } \\
\text { Schwarz }\end{array}$ & $\begin{array}{l}\text { Maximiza a probabilidade de se identificaro } \\
\text { verdadeiro modelo dentre os avaliados. }\end{array}$ & $\begin{array}{l}\text { Valores } \\
\text { positivos } \\
\text { menores }\end{array}$ \\
\hline $\begin{array}{l}\text { SRMR - Standardized } \\
\text { Root Mean Square } \\
\text { Residual }\end{array}$ & $\begin{array}{l}\text { Busca avaliar a distância entre os parâmetros } \\
\text { estimados do modelo e os dados da matriz } \\
\text { de covariância ou correlação da amostra. }\end{array}$ & $\begin{array}{l}\text { Valores } \\
\text { pequenos }\end{array}$ \\
\hline
\end{tabular}

Figura 17. Definição dos índices de ajuste do modelo utilizados na pesquisa

Fonte: elaborado pela autora

Após a verificação dos índices de ajuste, sugere-se que se proceda à inspeção dos resíduos, que são as covariâncias ou correlações residuais entre as variáveis. Essa inspeção, assim como os índices de ajuste, também fornece um indicativo da qualidade do modelo. Dessa forma, os resíduos devem ser baixos, próximos a zero, e simetricamente distribuídos entre as variáveis. É possível que altos valores residuais sejam observados mesmo quando o 
modelo apresenta um bom ajuste, o que pode ser um indicativo para mudanças nos parâmetros (Ullman, 2007).

Por fim, de acordo com Weston \& Gore Jr. (2006), deve-se avaliar a força e a significância dos parâmetros estimados, além da variância explicada das variáveis endógenas observáveis ou latentes. Nessa etapa, o pesquisador poderá verificar se as relações estabelecidas teoricamente são confirmadas e significativas (Hair et al., 2009). Geralmente, utilizam-se os coeficientes padronizados para análise e discussão dos dados, pois muitas vezes, devido às diferenças nas escalas utilizadas, a interpretação dos coeficientes não padronizados é mais complexa (Ullman, 2007).

No próximo capítulo, serão apresentados e discutidos os resultados encontrados na presente pesquisa, observando os objetivos geral e específicos traçados na introdução e levando-se em conta a teoria apresentada no referencial teórico. 


\section{RESULTADOS E DISCUSSÕES}

Neste capítulo, são apresentados e discutidos os resultados encontrados no presente estudo. Os resultados estão relatados na sequência dos objetivos específicos e geral, ou seja, inicialmente, são discutidos os resultados das análises estatísticas descritivas da percepção de políticas e práticas de gestão de pessoas e das intenções comportamentais de comprometimento organizacional dos servidores do MMA. Em seguida, são apresentados e discutidos os resultados da análise de variância (ANOVA) e do teste $t$ para amostras independentes, para a análise dos dados sociodemográficos e profissionais, com objetivo de verificar as diferenças entre as médias desses dados nas variáveis estudadas, atendendo-se o terceiro e último objetivo específico. E por fim, são apresentados os resultados da Modelagem por Equações Estruturais (MEE), a partir dos quais são discutidas as evidências que respondem a pergunta de pesquisa: quais efeitos de políticas e práticas de gestão de pessoas sobre o comprometimento organizacional de servidores do MMA?

\subsection{Análises descritivas}

Nesta seção, com objetivo de atender aos dois primeiros objetivos específicos, são apresentados os resultados das estatísticas descritivas, contendo as médias e desvios-padrão da percepção de políticas e práticas de gestão de pessoas e das intenções comportamentais de comprometimento organizacional dos servidores do MMA. A percepção de políticas e práticas de gestão de pessoas foi mensurada por meio da Escala de Políticas e Práticas de Recursos Humanos (EPPRH), composta por seis fatores (recrutamento e seleção; envolvimento; treinamento, desenvolvimento e educação (TD\&E); condições de trabalho; avaliação de desempenho e competências; e remuneração e recompensas). Já as intenções comportamentais de comprometimento organizacional foram mensuradas por meio da Escala de Intenções Comportamentais de Comprometimento Organizacional (EICCO), sendo uma medida unidimensional.

\subsubsection{Percepção de Políticas e Práticas de Gestão de Pessoas}

A interpretação dos resultados da EPPRH ocorre da seguinte forma: quanto maior for o valor da média aritmética obtida, mais o respondente atesta sua concordância com o conteúdo avaliado por um determinado fator. Dessa forma, valores entre 1 e 2,9 representam discordância, ou seja, o respondente não percebe a política de gestão de pessoas em questão. Valores entre 3 e 3,9 denotam indiferença do respondente, e, por fim, valores entre 4 e 5 são 
indicadores de concordância. Assim, enquanto a média não chegar a 5 há espaço para melhorias na gestão de pessoas (Demo et al., 2014).

A Tabela 6 apresenta as médias e os desvios-padrão relativos aos itens da EPPRH, dividida pelos fatores que compõem a referida escala.

Tabela 6. Estatística descritiva dos itens da EPPRH por fatores

FATOR - RECRUTAMENTO E SELEÇÃO

\begin{tabular}{lcc}
\hline \multicolumn{1}{c}{ Itens } & Média & Desvio-padrão \\
\hline $\begin{array}{l}\text { 1. Os processos de recrutamento (externo e interno) de candidatos a } \\
\text { ocuparem vagas na organização onde eu trabalho são amplamente } \\
\text { divulgados. }\end{array}$ & 3,05 & 1,43 \\
$\begin{array}{l}\text { 2. Os processos seletivos da organização onde eu trabalho são } \\
\text { disputados, atraindo pessoas competentes. }\end{array}$ & 3,37 & 1,26 \\
$\begin{array}{l}\text { 3. Os testes de seleção da organização onde eu trabalho são } \\
\text { conduzidos por pessoas capacitadas e imparciais. }\end{array}$ & 3,26 & 1,16 \\
$\begin{array}{l}\text { 4. A organização onde eu trabalho utiliza-se de vários instrumentos } \\
\text { de seleção (ex: entrevistas, provas, etc.). }\end{array}$ & 2,69 & 1,28 \\
$\begin{array}{l}\text { 5. A organização onde eu trabalho divulga aos candidatos } \\
\text { informações a respeito das etapas e critérios do processo seletivo. }\end{array}$ & 3,54 & 1,30 \\
$\begin{array}{l}\text { 6. A organização onde eu trabalho comunica aos candidatos seu } \\
\text { desempenho ao final do processo seletivo. }\end{array}$ & 3,46 & 1,32 \\
\begin{tabular}{l} 
Total do Fator \\
\hline
\end{tabular} & $\mathbf{3 , 2 3}$ & $\mathbf{0 , 9 6}$ \\
\hline
\end{tabular}

FATOR - ENVOLVIMENTO

\begin{tabular}{|c|c|c|}
\hline Itens & Média & Desvio-padrão \\
\hline 7. A organização onde eu trabalho se preocupa com meu bem-estar. & 2,75 & 1,29 \\
\hline 8. A organização onde eu trabalho me trata com respeito e atenção. & 3,22 & 1,28 \\
\hline $\begin{array}{l}\text { 9. A organização onde eu trabalho procura conhecer minhas } \\
\text { necessidades e expectativas profissionais. }\end{array}$ & 2,24 & 1,19 \\
\hline $\begin{array}{l}\text { 10. A organização onde eu trabalho estimula a minha participação } \\
\text { nas tomadas de decisão e resolução de problemas. }\end{array}$ & 2,41 & 1,25 \\
\hline $\begin{array}{l}\text { 11. A organização onde eu trabalho reconhece o trabalho que faço e } \\
\text { os resultados que apresento (ex: elogios, matérias em jornais } \\
\text { internos, etc.). }\end{array}$ & 2,73 & 1,26 \\
\hline $\begin{array}{l}\text { 12. Na organização onde eu trabalho, os colaboradores e suas } \\
\text { chefias desfrutam da troca constante de informações para o bom } \\
\text { desempenho das funções. }\end{array}$ & 2,71 & 1,38 \\
\hline $\begin{array}{l}\text { 13. Na organização onde eu trabalho, há um clima de compreensão } \\
\text { e confiança dos chefes em relação aos seus colaboradores. }\end{array}$ & 3,03 & 1,32 \\
\hline $\begin{array}{l}\text { 14. Na organização onde eu trabalho, há um clima de confiança e } \\
\text { cooperação entre os colegas de trabalho. }\end{array}$ & 3,60 & 1,16 \\
\hline $\begin{array}{l}\text { 15. Na organização onde eu trabalho, há coerência entre discurso e } \\
\text { prática gerenciais. }\end{array}$ & 2,43 & 1,28 \\
\hline Total do Fator & 2,79 & 0,98 \\
\hline
\end{tabular}


FATOR - TREINAMENTO, DESENVOLVIMENTO E EDUCAÇÃO (TD\&E)

\begin{tabular}{lcc}
\hline \multicolumn{1}{c}{ Itens } & Média & Desvio-padrão \\
\hline $\begin{array}{l}\text { 16. A organização onde eu trabalho me ajuda a desenvolver as } \\
\text { competências necessárias à boa realização das minhas funções (ex: }\end{array}$ & 3,12 & 1,36 \\
treinamentos, participação em congressos, etc.). & & \\
$\begin{array}{l}\text { 17. Eu consigo aplicar no meu trabalho os conhecimentos e } \\
\text { comportamentos aprendidos nos treinamentos/eventos de que } \\
\text { participo. }\end{array}$ & 3,47 & 1,20 \\
$\begin{array}{l}\text { 18. A organização onde eu trabalho estimula a aprendizagem e a } \\
\text { produção de conhecimento. }\end{array}$ & 3,35 & 1,22 \\
Total do Fator & $\mathbf{3 , 3 1}$ & $\mathbf{1 , 0 6}$ \\
\hline
\end{tabular}

\begin{tabular}{lcc}
\hline \multicolumn{1}{c}{ FATOR - CONDIÇÕES DE TRABALHO } & & \\
\hline \multicolumn{1}{c}{ Itens } & Média & Desvio-padrão \\
\hline $\begin{array}{l}\text { 19. A organização onde eu trabalho preocupa-se com a minha saúde } \\
\text { e qualidade de vida. }\end{array}$ & 2,72 & 1,19 \\
$\begin{array}{l}\text { 20. A organização onde eu trabalho me oferece benefícios básicos } \\
\text { (ex: plano de saúde, auxílio transporte, auxílio alimentação, etc.). }\end{array}$ & 3,77 & 1,17 \\
$\begin{array}{l}\text { 21. Na organização onde eu trabalho, existem ações e programas de } \\
\text { prevenção de acidentes e enfrentamento de incidentes. }\end{array}$ & 2,26 & 1,21 \\
$\begin{array}{l}\text { 22. A organização onde eu trabalho preocupa-se com a segurança de } \\
\text { seus colaboradores, controlando o acesso de pessoas estranhas no }\end{array}$ & 3,26 & 1,32 \\
$\begin{array}{l}\text { órgão. } \\
\text { 23. As instalações e as condições físicas (iluminação, ventilação, } \\
\text { ruído e temperatura) do local onde eu trabalho são ergonômicas } \\
\text { (adequadas e confortáveis). }\end{array}$ & 3,04 & 1,35 \\
\begin{tabular}{l} 
Total do Fator \\
\hline
\end{tabular} & $\mathbf{3 , 0 1}$ & $\mathbf{0 , 8 4}$ \\
\hline
\end{tabular}

FATOR - AVALIAÇÃO DE DESEMPENHO E COMPETÊNCIAS

\begin{tabular}{|c|c|c|}
\hline Itens & Média & Desvio-padrão \\
\hline $\begin{array}{l}\text { 24. A organização onde eu trabalho realiza avaliações de } \\
\text { desempenho e competências periodicamente. }\end{array}$ & 4,23 & 0,95 \\
\hline $\begin{array}{l}\text { 25. Na organização onde eu trabalho, a avaliação de desempenho e } \\
\text { competências subsidia as decisões sobre promoções e aumento de } \\
\text { remuneração. }\end{array}$ & 2,84 & 1,50 \\
\hline $\begin{array}{l}\text { 26. Na organização onde eu trabalho, a avaliação de desempenho e } \\
\text { competências subsidia a elaboração de um plano de } \\
\text { desenvolvimento dos colaboradores. }\end{array}$ & 2,65 & 1,39 \\
\hline $\begin{array}{l}\text { 27. Na organização onde eu trabalho, os critérios e os resultados da } \\
\text { avaliação de desempenho e competências são discutidos com os } \\
\text { colaboradores. }\end{array}$ & 2,79 & 1,36 \\
\hline $\begin{array}{l}\text { 28. Na organização onde eu trabalho, os critérios e os resultados da } \\
\text { avaliação de desempenho e competências são divulgados para os } \\
\text { colaboradores. }\end{array}$ & 3,20 & 1,33 \\
\hline Total do Fator & 3,14 & 0,98 \\
\hline
\end{tabular}




\section{FATOR - REMUNERAÇÃO E RECOMPENSAS}

\begin{tabular}{lcc}
\hline \multicolumn{1}{c}{ Itens } & Média & Desvio-padrão \\
\hline $\begin{array}{l}\text { 29. A organização onde eu trabalho me oferece remuneração } \\
\text { compatível com as minhas competências e formação/escolaridade. }\end{array}$ & 3,22 & 1,34 \\
$\begin{array}{l}\text { 30. Na organização onde eu trabalho, recebo incentivos (ex: } \\
\text { promoções/cargos comissionados, prêmios/gratificações, etc.). }\end{array}$ & 2,48 & 1,37 \\
$\begin{array}{l}\text { 31. Nas negociações que envolvem reestruturação da carreira, a } \\
\text { organização onde eu trabalho considera as expectativas e sugestões } \\
\text { de seus colaboradores. }\end{array}$ & 2,50 & 1,18 \\
$\begin{array}{l}\text { 32. Na organização onde eu trabalho, minha remuneração é } \\
\text { influenciada pelos meus resultados. }\end{array}$ & 2,45 & 1,41 \\
Total do Fator & $\mathbf{2 , 6 6}$ & $\mathbf{0 , 9 6}$ \\
\hline
\end{tabular}

Fonte: dados da pesquisa

Dessa forma, com base nos resultados, pode-se inferir que os servidores do MMA não concordam com nenhuma das políticas e práticas de gestão de pessoas do órgão, uma vez que a maior média entre os fatores foi da política de Treinamento, Desenvolvimento e Educação (TD\&E) (3,31), mas, ainda assim, o resultado demonstra indiferença dos respondentes com a referida política, uma vez que encontra-se situada entre os valores de 3 e 3,9, assim como as políticas de Recrutamento e Seleção $(3,23)$, Condições de Trabalho $(3,01)$ e Avaliação de Desempenho e Competências $(3,14)$.

Em contraponto, a política que obteve a menor média foi a de Remuneração e Recompensas $(2,66)$, podendo-se inferir que os servidores do MMA não percebem a referida política e práticas que vêm sendo adotadas pelo órgão, assim como a política de Envolvimento $(2,79)$, que também encontra-se entre os valores que representam discordância dos servidores. Com relação à política de Remuneração e Recompensas, cabe acrescentar que a remuneração dos servidores públicos federais é estabelecida por lei, como prevê a Lei $\mathrm{n}^{\circ}$ 8.112 (1990), em seu art. 41. E compete à Secretaria de Gestão Pública do Ministério do Planejamento, Orçamento e Gestão (SEGEP/MP) a formalização de políticas e diretrizes para a gestão pública, no âmbito da administração pública federal, compreendendo os planos de cargos e carreiras e a estrutura remuneratória dos cargos, conforme dispõe o Decreto $\mathrm{n}^{\mathrm{o}} 8.189$ (2014). Dessa forma, quanto à referida política, os órgãos setoriais (MMA) não dispõem de autonomia para melhorá-la individualmente, somente por meio de negociações com a SEGEP/MP.

Pode-se dizer que os resultados condizem com as características da gestão de pessoas no serviço público, que apesar de tentar implementar práticas advindas da iniciativa privada, buscando criar um enfoque estratégico, sofre grande impacto da legislação e qualquer forma 
de ação está restrita ao que é legalmente determinado, ainda prevalece uma grande rigidez nos procedimentos, e é difícil de mensurar o desempenho da área devido à influência política que sofrem as decisões sobre gestão de pessoas no serviço público (Castillo Blanco, 2003).

No entanto, cabe acrescentar que as outras cinco políticas (recrutamento e seleção, envolvimento, TD\&E, condições de trabalho e avaliação de desempenho e competências), por mais que haja, na maioria delas, diretrizes da SEGEP/MP para sua execução, os órgãos setoriais (MMA) dispõem de maior autonomia para o planejamento e execução de práticas que visem melhorá-las e adequá-las aos servidores do órgão.

\subsubsection{Intenções Comportamentais de Comprometimento Organizacional}

Para interpretação dos resultados da EICCO, deve-se levar em consideração que a demonstração de uma postura proativa indica comprometimento com a organização (Menezes e Bastos, 2010). Assim, por ser um modelo de escala do tipo diferencial semântico de 7 pontos, valores de 1 a 3,9 demonstram uma postura de baixo comprometimento com a organização, de 4 a 4,9 denotam indiferença do participante, e de 5 a 7 são indicadores de postura proativa, indicando a intenção comportamental de comprometimento com a organização.

A Tabela 7 apresenta as médias e os desvios-padrão relativos aos itens da EICCO, em uma estrutura unidimensional.

Tabela 7. Estatística descritiva da EICCO

\begin{tabular}{|c|c|c|}
\hline Itens & Média & Desvio-padrão \\
\hline $\begin{array}{l}\text { 1. Eu compareceria a reuniões de voluntários uma vez por semana, } \\
\text { após o expediente, sem pagamento de horas-extras, a fim de discutir } \\
\text { questões de interesse da própria organização, caso eu tivesse tal horário } \\
\text { disponível. }\end{array}$ & 0,44 & 2,18 \\
\hline $\begin{array}{l}\text { 2. Eu aceitaria a proposta de substituir um colega de outro setor } \\
\text { durante um mês e buscaria aprender as novas tarefas. }\end{array}$ & 1,94 & 1,47 \\
\hline $\begin{array}{l}\text { 3. Aceitaria assumir encargos ou tarefas que se distanciam de meus } \\
\text { interesses profissionais atuais para atender às necessidades da } \\
\text { organização. }\end{array}$ & 0,87 & 1,72 \\
\hline $\begin{array}{l}\text { 4. Eu defenderia a organização caso, em um contexto fora da } \\
\text { organização, algumas pessoas que não trabalham nela fizessem } \\
\text { comentários, criticando-a injustamente. }\end{array}$ & 1,65 & 1,52 \\
\hline $\begin{array}{l}\text { 5. Se devido a algum motivo irrelevante, haja divergências e tensões } \\
\text { entre diferentes setores dentro da organização em que trabalha, eu } \\
\text { interviria no sentido de ajudar a superar as divergências e tensões. }\end{array}$ & 0,58 & 1,82 \\
\hline $\begin{array}{l}\text { 6. Se a minha chefia me solicitasse um aumento de produtividade por } \\
\text { tempo indeterminado, mantendo as mesmas condições de trabalho, } \\
\text { mesmo eu tendo uma produtividade satisfatória, eu procuraria melhorar } \\
\text { minha produtividade e meu desempenho. }\end{array}$ & 1,08 & 1,79 \\
\hline
\end{tabular}


7. Se eu tivesse uma ideia inovadora que poderia reduzir o tempo de trabalho e torná-lo mais diversificado, eu difundiria minha ideia para a organização.

8. Se minha chefia me solicitasse um aumento de produtividade, buscando a melhoria do desempenho geral da equipe, mesmo eu tendo atingido o desempenho esperado, eu buscaria elevar o meu nível de produtividade.

9. Se outra equipe de trabalho, próxima a minha, me solicitasse auxílio para a finalização das tarefas, eu ajudaria.

10. Se a organização estiver com o quadro de pessoal reduzido, requerendo de mim a realização de mais tarefas do que as exigidas para o meu cargo, tendo em vista a necessidade de atingimento das metas organizacionais, eu assumiria essas novas tarefas.

11. Se a organização me solicitar engajamento em atividades para melhorar a forma como a organização é vista pela sociedade, eu tomaria alguma iniciativa no sentido de promover tal melhoria.

12. Se em uma conversa descontraída com meus colegas de trabalho, um deles questionasse e criticasse injustamente a organização, eu a defenderia.

13. Se a organização em que trabalho adotasse um modelo de gestão participativa para que seus funcionários pudessem se envolver no processo de elaboração de novos projetos, a partir do próximo ano, eu me ofereceria para participar desses novos projetos.

14. Se organização redefinisse as metas de desempenho para o próximo ano e isso fosse exigir de mim uma carga de trabalho adicional, eu mudaria minha forma de trabalhar para me adequar às novas metas.

15. Se a organização implementasse programas de melhoria do seu desempenho e da qualidade de seus serviços, eu me engajaria no programa, mesmo se fosse exigido mudanças na minha forma de trabalhar e a necessidade de uma nova adaptação ao meu trabalho.

16. Se a organização implantasse um sistema de críticas e sugestões acessível a todos os funcionários, eu as apresentaria à organização.

17. Se um dos clientes da organização na qual trabalho dirigisse críticas ao atendimento prestado pelo órgão e insinuasse que outros órgãos possuem uma qualidade de atendimento superior, eu defenderia a organização das críticas do cliente.

18. Se a organização onde trabalho estivesse sendo reestruturada, implicando em redimensionamento de setores e remanejamento de pessoal, e se essas mudanças fossem vistas pela organização como necessárias para a melhoria de seu desempenho, eu mudaria de setor, caso fosse necessário.

19. Se dificuldades financeiras levassem a organização a restringir benefícios e vantagens que estavam sendo oferecidos aos colaboradores, eu tomaria alguma iniciativa no sentido de evitar tais restrições, se possível.

20. Se a organização estiver enfrentando um problema cujo encaminhamento está confiado a um outro setor de trabalho que não é o meu, eu me ofereceria para ajudar, caso eu tivesse alguma ideia de como resolvê-lo. 
Nesse sentido, observando o resultado, infere-se que a postura dos servidores do MMA indica intenção comportamental de baixo comprometimento organizacional. Nenhum dos itens da escala aplicada alcançou média superior a 4,9, que caracterizaria uma postura proativa, indicando o comprometimento organizacional. Os itens que obtiveram maior média foram os seguintes: 9) ajudar outra equipe a finalizar suas atividades $(2,24), 7)$ difundir uma ideia inovadora que poderia reduzir o tempo de trabalho e torná-lo mais diversificado $(2,19)$, e 16) apresentar críticas e sugestões à organização $(2,17)$. Porém, mesmo os itens que tiveram maior média apresentaram valores abaixo de uma intenção de comportamento comprometido com a organização.

Ao contrário dos achados na presente pesquisa, o estudo de Demo et al. (2013), que teve como objetivo avaliar a relação entre políticas de gestão de pessoas, comprometimento organizacional e satisfação no trabalho, com base na percepção dos colaboradores da Livraria Cultura, filial Brasília, mostrou que as políticas e práticas de gestão de pessoas, de maneira geral, estavam sendo percebidas pelos colaboradores da livraria, com destaque para as condições de trabalho. E os colaboradores eram comprometidos com a organização, principalmente com relação à base afetiva. Essa diferença nos resultados talvez tenha se dado em virtude das peculiaridades dos contextos estudados (empresa privada e administração pública federal direta).

\subsection{ANOVA e Teste $t$ das diferenças entre as médias}

Nesta seção, são apresentados os resultados das análises de diferenças entre as médias (ANOVA e teste $\mathrm{t}$ para amostras independentes), com objetivo de comparar os dados sociodemográficos (idade, escolaridade e sexo) e profissionais (unidade de lotação, carreira, tempo de serviço, participação em programas de incentivos e ocupação de cargo em comissão) com as variáveis estudadas (percepção de políticas e práticas de gestão de pessoas e intenções comportamental de comprometimento organizacional), atendendo-se, assim, ao terceiro e último objetivo específico.

A percepção de políticas e práticas de gestão de pessoas foi avaliada com base nos seis fatores constantes da EPPRH (recrutamento e seleção; envolvimento; treinamento, desenvolvimento e educação (TD\&E); condições de trabalho; avaliação de desempenho e competências; e remuneração e recompensas), e o comprometimento organizacional com base na estrutura unidimensional da EICCO. Dessa forma, cada um dos seis fatores da EPPRH e o único fator da EICCO foram analisados em relação às variáveis sociodemográficas e às 
profissionais, com objetivo de verificar se havia diferença significativa entre as médias dos grupos. As análises das variáveis - idade, escolaridade, unidade de lotação, carreira e tempo de serviço - foram realizadas por meio da ANOVA. Já as variáveis - sexo, participação em programa de incentivos e ocupação de cargo em comissão - foram analisadas utilizando-se o teste t, para amostras independentes, por serem variáveis dicotômicas.

Ao iniciar as análises da ANOVA, verificou-se que a variável escolaridade possuía uma categoria (ensino fundamental completo) com apenas um respondente. Dessa forma, essa categoria foi excluída da ANOVA, uma vez que, de acordo com Tabachnick e Fidell (2001), as variáveis necessitam de pelo menos dois sujeitos respondentes e pelo menos duas categorias contendo mais de um sujeito respondente em cada. Da mesma forma, a variável unidade de lotação apresentou duas categorias (Assessoria Parlamentar (ASPAR) e Consultoria Jurídica (CONJUR)) com apenas um sujeito respondente em cada. Assim, decidiu-se agrupar as unidades ASPAR, CONJUR, Assessoria de Comunicação Social ASCOM e Assessoria Internacional - ASIN na categoria Gabinete da Ministra - GM, em virtude da subordinação hierárquica das referidas unidades ao GM.

A seguir, são apresentados os resultados da ANOVA em relação aos fatores da EPPRH e às variáveis sociodemográficas e profissionais que obtiveram diferenças significativas entre as médias.

Tabela 8. ANOVA da variável idade com os fatores da EPPRH

\begin{tabular}{clcccccc}
\hline \multirow{2}{*}{ Fator } & \multicolumn{1}{c}{ Idade } & N & Média & $\begin{array}{c}\text { Desvio- } \\
\text { Padrão }\end{array}$ & F & df & p \\
\hline \multirow{5}{*}{ Envolvimento } & De 21 a 30 anos & 67 & 2,84 & 0,98 & & & \\
& De 31 a 40 anos & 90 & 2,77 & 0,97 & & & \\
& De 41 a 50 anos & 40 & 2,38 & 0,93 & $\mathbf{3 , 7 1}$ & 4 & $\mathbf{0 , 0 0 6}$ \\
& De 51 a 60 anos & 37 & 3,08 & 0,98 & & & \\
& Acima de 60 anos & 4 & 3,78 & 0,31 & & & \\
\hline
\end{tabular}

Fonte: dados da pesquisa

Ao analisar a Tabela 8, verifica-se que houve diferença significativa entre as médias das categorias da variável idade em relação ao fator de percepções de política de Envolvimento da EPPRH. A ANOVA para o referido fator resultou no valor de $F(4,233)=$ $3,71, p=0,006, \omega^{2}=0,04$. Com objetivo de identificar para qual ou quais categorias as diferenças de médias foram significativas, realizou-se o teste Post Hoc - Tukey, com intervalo de confiança de $95 \%$, conforme apresentado na tabela a seguir: 
Tabela 9. Resultado do teste Post Hoc/Tukey - EPPRH/Idade

\begin{tabular}{cccccc}
\hline \multirow{2}{*}{ Fator } & \multirow{2}{*}{ Idade $(\mathbf{I})$} & Idade $(\mathbf{J})$ & $\begin{array}{c}\text { Mean Difference } \\
(\boldsymbol{I}-\boldsymbol{J})\end{array}$ & $\begin{array}{c}\text { Std. } \\
\text { Error }\end{array}$ & p \\
\hline \multirow{2}{*}{ Envolvimento } & \multirow{2}{*}{ De 41 a 50 anos } & De 51 a 60 anos & $-0,69$ & 0,22 & $\mathbf{0 , 0 1 6}$ \\
& & Acima de 60 anos & $-1,39$ & 0,50 & $\mathbf{0 , 0 4 8}$ \\
\hline
\end{tabular}

Nota: $\mathrm{p}<0,05$

Fonte: dados da pesquisa

A partir do resultado do teste Post Hoc, verifica-se que a média dos respondentes com idade entre 41 a 50 anos $(\mathrm{M}=2,38, \mathrm{DP}=0,93)$ foi significativamente mais baixa do que os que estão nas faixas etárias de 51 a 60 anos $(\mathrm{M}=3,08, \mathrm{DP}=0,98)$ e acima de 60 anos $(\mathrm{M}=3,78$, $\mathrm{DP}=0,31$ ). Assim, pode-se inferir que os servidores com idade acima de 51 anos são mais indiferentes com relação à política de Envolvimento do que os que estão na faixa etária de 41 a 50 anos. Estes últimos não percebem à referida política. Esse resultado pode ser em virtude do servidor de mais idade estar vivenciando poucas práticas ou nenhuma que caracterizem o envolvimento dos servidores, como reconhecimento, integração, participação e cooperação, do que aqueles que estão em faixa etária menor.

Tabela 10. ANOVA da variável unidade de lotação com os fatores da EPPRH

\begin{tabular}{|c|c|c|c|c|c|c|c|}
\hline Fator & $\begin{array}{l}\text { Unidade de } \\
\text { lotação }\end{array}$ & $\mathbf{N}$ & Média & $\begin{array}{l}\text { Desvio- } \\
\text { Padrão }\end{array}$ & $\mathbf{F}$ & df & p \\
\hline \multirow{9}{*}{ Envolvimento } & GM & 9 & 2,28 & 0,81 & \multirow{9}{*}{4,25} & \multirow{9}{*}{8} & \multirow{9}{*}{$<0,001$} \\
\hline & SECEX & 30 & 2,80 & 0,92 & & & \\
\hline & SPOA/SECEX & 49 & 3,36 & 1,10 & & & \\
\hline & SAIC & 14 & 2,50 & 0,98 & & & \\
\hline & SBF & 23 & 2,30 & 0,91 & & & \\
\hline & SEDR & 17 & 2,38 & 0,74 & & & \\
\hline & SFB & 57 & 2,88 & 0,90 & & & \\
\hline & SMCQ & 16 & 2,47 & 0,87 & & & \\
\hline & SRHU & 18 & 2,80 & 0,85 & & & \\
\hline \multirow{9}{*}{ TD\&E } & GM & 9 & 3,52 & 1,08 & \multirow{9}{*}{4,19} & \multirow{9}{*}{8} & \multirow{9}{*}{$<0,001$} \\
\hline & SECEX & 30 & 3,39 & 1,02 & & & \\
\hline & SPOA/SECEX & 49 & 4,00 & 0,96 & & & \\
\hline & SAIC & 14 & 2,76 & 1,00 & & & \\
\hline & SBF & 23 & 3,10 & 1,00 & & & \\
\hline & SEDR & 17 & 3,02 & 0,98 & & & \\
\hline & SFB & 57 & 3,20 & 1,03 & & & \\
\hline & SMCQ & 16 & 3,00 & 0,94 & & & \\
\hline & SRHU & 18 & 3,06 & 1,06 & & & \\
\hline \multirow{9}{*}{$\begin{array}{c}\text { Condições de } \\
\text { Trabalho }\end{array}$} & GM & 9 & 2,98 & 0,81 & \multirow{9}{*}{3,09} & \multirow{9}{*}{8} & \multirow{9}{*}{$\mathbf{0 , 0 0 3}$} \\
\hline & SECEX & 30 & 2,99 & 0,75 & & & \\
\hline & SPOA/SECEX & 49 & 3,35 & 1,02 & & & \\
\hline & SAIC & 14 & 2,67 & 0,75 & & & \\
\hline & SBF & 23 & 2,57 & 0,77 & & & \\
\hline & SEDR & 17 & 2,72 & 0,68 & & & \\
\hline & SFB & 57 & 3,21 & 0,78 & & & \\
\hline & SMCQ & 16 & 2,78 & 0,81 & & & \\
\hline & SRHU & 18 & 2,90 & 0,57 & & & \\
\hline
\end{tabular}




\begin{tabular}{clcccccc}
\hline & GM & 9 & 2,98 & 1,09 & & & \\
& SECEX & 30 & 3,25 & 1,15 & & & \\
& SPOA/SECEX & 49 & 3,51 & 0,93 & & & \\
Avaliação de & SAIC & 14 & 2,91 & 1,04 & & & \\
Desempenho e & SBF & 23 & 2,79 & 0,80 & $\mathbf{2 , 0 5}$ & 8 & $\mathbf{0 , 0 4 2}$ \\
Competências & SEDR & 17 & 2,78 & 0,82 & & & \\
& SFB & 57 & 3,25 & 0,98 & & & \\
& SMCQ & 16 & 2,88 & 0,93 & & & \\
& SRHU & 18 & 2,98 & 0,90 & & & \\
& GM & 9 & 2,78 & 0,90 & & & \\
Remuneração e & SECEX & 30 & 2,53 & 0,97 & & & \\
Recompensas & SPOA/SECEX & 49 & 3,22 & 1,01 & & & \\
& SAIC & 14 & 2,34 & 0,92 & & & \\
& SBF & 23 & 2,34 & 0,96 & $\mathbf{4 , 1 4}$ & 8 & $<\mathbf{0 , 0 0 1}$ \\
& SEDR & 17 & 2,53 & 0,76 & & & \\
& SFB & 57 & 2,74 & 0,90 & & & \\
& SMCQ & 16 & 2,17 & 0,79 & & & \\
& SRHU & 18 & 2,25 & 0,70 & & & \\
\hline
\end{tabular}

Fonte: dados da pesquisa

De acordo com a Tabela 10, observa-se que a ANOVA da relação mostrou que há diferenças significativas entre a variável unidade de lotação em relação aos fatores de percepções de política de Envolvimento, Treinamento, Desenvolvimento e Educação (TD\&E), Condições de Trabalho, Avaliação de Desempenho e Competências e Remuneração e Recompensas. A ANOVA do fator Envolvimento resultou no valor de $F(8,224)=4,25, p<$ 0,001, $\omega^{2}=0,10$, do fator de TD\&E o valor foi de $F(8,224)=4,19, p<0,001, \omega^{2}=0,10$, de Condições de Trabalho o resultado foi $F(8,224)=3,09, p=0,003, \omega^{2}=0,07$, já o fator de Avaliação de Desempenho e Competências o valor da ANOVA foi de $F(8,224)=2,05, p=$ 0,042, $\omega^{2}=0,03$, e, por fim, o resultado do fator Remuneração e Recompensas foi de $F(8$, 224) $=4,14, p<0,001, \omega^{2}=0,10$.

Com objetivo de identificar para qual ou quais categorias as diferenças de médias foram significativas, realizou-se o teste Post Hoc - Tukey, com intervalo de confiança de 95\%, conforme apresentado na tabela a seguir:

Tabela 11. Resultado do teste Post Hoc/Tukey - EPPRH/Unidade de Lotação

\begin{tabular}{cccccc}
\hline \multirow{2}{*}{ Fator } & $\begin{array}{c}\text { Unidade de } \\
\text { lotação (I) }\end{array}$ & $\begin{array}{c}\text { Unidade de } \\
\text { lotação (J) }\end{array}$ & $\begin{array}{c}\text { Mean } \\
\text { Difference }(\text { I-J) }\end{array}$ & Std. Error & p \\
\hline \multirow{4}{*}{ Envolvimento } & & GM & 1,08 & 0,34 & $\mathbf{0 , 0 4 5}$ \\
& & SBF & 1,06 & 0,24 & $<\mathbf{0 , 0 0 1}$ \\
& \multirow{2}{*}{ SPOA/SECEX } & SEDR & 0,98 & 0,26 & $\mathbf{0 , 0 0 8}$ \\
& & SMCQ & 0,89 & 0,27 & $\mathbf{0 , 0 3 1}$ \\
\hline \multirow{4}{*}{ TD\&E } & & SAIC & 1,24 & 0,30 & $\mathbf{0 , 0 0 2}$ \\
& \multirow{2}{*}{ SPOA/SECEX } & SBF & 0,90 & 0,25 & $\mathbf{0 , 0 1 4}$ \\
& & SEDR & 0,98 & 0,28 & $\mathbf{0 , 0 1 8}$ \\
& & SFB & 0,79 & 0,20 & $\mathbf{0 , 0 0 2}$ \\
& & SMCQ & 1,00 & 0,29 & $\mathbf{0 , 0 1 8}$ \\
& & SRHU & 0,94 & 0,28 & $\mathbf{0 , 0 2 1}$ \\
\hline
\end{tabular}




\begin{tabular}{cccccc}
\hline Condições de & SPOA/SECEX & \multirow{2}{*}{ SBF } & 0,77 & 0,21 & $\mathbf{0 , 0 0 7}$ \\
Trabalho & SFB & & 0,64 & 0,20 & $\mathbf{0 , 0 4 4}$ \\
\hline & & SECEX & 0,69 & 0,21 & $\mathbf{0 , 0 3 3}$ \\
Remuneração e & \multirow{2}{*}{ SPOA/SECEX } & SAIC & 0,88 & 0,28 & $\mathbf{0 , 0 4 1}$ \\
Recompensas & SBF & 0,89 & 0,23 & $\mathbf{0 , 0 0 5}$ \\
& & SMCQ & 1,05 & 0,26 & $\mathbf{0 , 0 0 3}$ \\
& & SRHU & 0,97 & 0,25 & $\mathbf{0 , 0 0 4}$ \\
\hline
\end{tabular}

Nota: $p<0,05$

Fonte: dados da pesquisa

Com base no resultado do teste Post Hoc, pode-se inferir que os servidores lotados na Subsecretaria de Planejamento, Orçamento e Administração (SPOA/SECEX) (M=3,36, $\mathrm{DP}=1,10)$ são mais indiferentes com relação à política de Envolvimento, do que os servidores lotados no GM (M=2,28, DP=0,81), na Secretaria de Biodiversidade e Florestas (SBF) $(\mathrm{M}=2,30, \mathrm{DP}=0,91)$, na Secretaria de Extrativismo e Desenvolvimento Rural Sustentável (SEDR) $(\mathrm{M}=2,38, \mathrm{DP}=0,74)$ e na Secretaria de Mudanças Climáticas e Qualidade Ambiental (SMCQ) $(\mathrm{M}=2,47, \mathrm{DP}=0,87)$. Estes últimos (GM, SBF, SEDR e SMCQ) não percebem ou não concordam com as atuais práticas da referida política.

Essa diferença significativa da percepção dos servidores lotados na SPOA/SECEX se repetiu nas demais políticas constantes na Tabela 10. No entanto, ao contrário da política de Envolvimento, na política de TD\&E, os servidores lotados na SPOA/SECEX (M=4,00, $\mathrm{DP}=0,96)$ apresentaram uma percepção significativamente mais alta com relação à política do que servidores lotados na Secretaria de Articulação Institucional e Cidadania Ambiental (SAIC) $(\mathrm{M}=2,76, \mathrm{DP}=1,00), \mathrm{SBF}(\mathrm{M}=3,10, \mathrm{DP}=1,00)$, SEDR $(\mathrm{M}=3,02, \mathrm{DP}=0,98)$, Serviço Florestal Brasileiro (SFB) $(\mathrm{M}=3,20, \mathrm{DP}=1,03)$, SMCQ $(\mathrm{M}=3,00, \mathrm{DP}=0,94)$ e Secretaria de Recursos Hídricos e Ambiente Urbano (SRHU) (M=3,06, DP=1,06), que ou discordam das atuais práticas ou são indiferentes.

Na política de Condições de Trabalho, a percepção dos servidores da SPOA/SECEX $(\mathrm{M}=3,35, \mathrm{DP}=1,02)$ se diferenciou significativamente somente da percepção dos servidores da SBF (M=2,57, DP=0,77), demonstrando que os servidores da SPOA/SECEX são indiferentes com relação à referida política e os servidores da SBF não a percebem ou discordam das práticas vigentes. Outra diferença significativa, com relação à política de Condições de Trabalho, foi entre os servidores lotados no SFB $(M=3,21$, DP=0,78) e na $\operatorname{SBF}(M=2,57$, $\mathrm{DP}=0,77)$. Assim, a partir desse resultado pode-se inferir que os servidores lotados na SPOA/SECEX e no SFB são mais indiferentes com a política de Condições de Trabalho do que os servidores lotados na SBF, que não percebem, talvez em virtude das três unidades estarem localizadas em prédios distintos (SPOA/SECEX - edifício sede; SFB - edifício do 
IBAMA; e SBF - edifício 505 norte) as políticas e práticas de condições de trabalho podem estar sendo implementadas de forma não igualitária.

Já na política de Remuneração e Recompensas, a diferença significativa entre as médias se deu entre a percepção dos servidores lotados na SPOA/SECEX (M=3,22, DP=1,01) e os servidores da Secretaria Executiva (SECEX) $(\mathrm{M}=2,53, \mathrm{DP}=0,97)$, SAIC $(\mathrm{M}=2,34$, $\mathrm{DP}=0,92)$, SBF $(\mathrm{M}=2,34, \mathrm{DP}=0,96)$, SMCQ $(\mathrm{M}=2,17, \mathrm{DP}=0,79)$ e SRHU $(\mathrm{M}=2,25$, DP=0,70), demonstrando que os servidores da SECEX, SAIC SBF, SMCQ e SRHU não percebem a política de Remuneração e Recompensas e os servidores da SPOA/SECEX são indiferentes com as atuais práticas. Para a política de Avaliação de Desempenho e Competências, não foi possível identificar qual ou quais categorias tiveram diferenças de médias significativas, por meio do primeiro teste Post Hoc. Dessa forma, optou-se por agrupar as unidades que realizam atividades finalísticas do órgão (SAIC, SBF, SEDR, SFB, SMCQ e SRHU) e manter as demais unidades (GM, SECEX e SPOA/SECEX), para que fosse realizada uma nova análise ANOVA.

Os resultados da nova análise confirmaram a diferença significativa existente entre as médias dos respondentes, a partir da variável unidade de lotação, para a política de Avaliação de Desempenho e Competências $\left(F(3,229)=3,40, p=0,018, \omega^{2}=0,03\right)$. Assim, procedeu-se um novo teste Post Hoc para identificar qual ou quais categorias as diferenças de médias foram significativas, conforme apresentado na Tabela 12:

Tabela 12. Resultado do teste Post Hoc/Tukey - EPPRH/Unidade de Lotação - após alteração

\begin{tabular}{cccccc}
\hline Fator & $\begin{array}{c}\text { Unidade de } \\
\text { lotação (I) }\end{array}$ & $\begin{array}{c}\text { Unidade de } \\
\text { lotação (J) }\end{array}$ & $\begin{array}{c}\text { Mean Difference } \\
(\text { I-J) }\end{array}$ & $\begin{array}{c}\text { Std. } \\
\text { Error }\end{array}$ & $\mathbf{p}$ \\
\hline $\begin{array}{c}\text { Avaliação de Desempenho e } \\
\text { Competências }\end{array}$ & SPOA/SECEX & $\begin{array}{c}\text { Unidades } \\
\text { finalísticas }\end{array}$ & 0,50 & 0,16 & $\mathbf{0 , 0 1 2}$ \\
\hline
\end{tabular}

Nota: $p<0,05$

Fonte: dados da pesquisa

O resultado do teste Post Hoc revelou que os servidores lotados nas unidades finalísticas (SAIC, SBF, SEDR, SFB, SMCQ e SRHU) (M=3,01, DP=0,93) sãos mais indiferentes com relação à referida política do que os servidores lotados na SPOA/SECEX $(\mathrm{M}=3,51, \mathrm{DP}=0,93)$.

Essa diferença significativa, encontrada em praticamente todas as políticas, com relação à indiferença dos servidores da SPOA/SECEX, pode ser justificada pela proximidade física dos servidores lotados na SPOA/SECEX com a Coordenação Geral de Gestão de Pessoas (CGGP/SPOA), e ainda pela vinculação hierárquica das duas unidades, o que pode ter causado um constrangimento nos servidores, impossibilitando o julgamento sincero com relação às políticas e práticas de gestão de pessoas, mesmo a pesquisa sendo anônima. 
Tabela 13. ANOVA da variável tempo de serviço no órgão com os fatores da EPPRH

\begin{tabular}{|c|c|c|c|c|c|c|c|}
\hline Fator & $\begin{array}{c}\text { Tempo de serviço } \\
\text { no órgão }\end{array}$ & $\mathbf{N}$ & Média & $\begin{array}{l}\text { Desvio- } \\
\text { Padrão }\end{array}$ & $\mathbf{F}$ & df & $\mathbf{p}$ \\
\hline \multirow{7}{*}{$\begin{array}{l}\text { Recrutamento e } \\
\text { Seleção }\end{array}$} & Menos de 1 ano & 26 & 3,79 & 0,70 & \multirow{7}{*}{2,78} & \multirow{7}{*}{6} & \multirow{7}{*}{$\mathbf{0 , 0 1 3}$} \\
\hline & De 1 a 3 anos & 70 & 3,14 & 0,91 & & & \\
\hline & De 4 a 8 anos & 79 & 3,06 & 1,04 & & & \\
\hline & De 9 a 13 anos & 43 & 3,17 & 0,95 & & & \\
\hline & De 14 a 19 anos & 4 & 3,54 & 0,37 & & & \\
\hline & De 20 a 30 anos & 10 & 3,72 & 1,00 & & & \\
\hline & Acima de 30 anos & 6 & 3,56 & 0,56 & & & \\
\hline \multirow{7}{*}{ Envolvimento } & Menos de 1 ano & 26 & 3,44 & 0,74 & \multirow{7}{*}{3,35} & \multirow{7}{*}{6} & \multirow{7}{*}{0,004} \\
\hline & De 1 a 3 anos & 70 & 2,85 & 0,94 & & & \\
\hline & De 4 a 8 anos & 79 & 2,54 & 0,94 & & & \\
\hline & De 9 a 13 anos & 43 & 2,65 & 1,10 & & & \\
\hline & De 14 a 19 anos & 4 & 2,89 & 0,97 & & & \\
\hline & De 20 a 30 anos & 10 & 3,01 & 1,03 & & & \\
\hline & Acima de 30 anos & 6 & 3,11 & 0,89 & & & \\
\hline \multirow{7}{*}{$\begin{array}{l}\text { Condições de } \\
\text { Trabalho }\end{array}$} & Menos de 1 ano & 26 & 3,47 & 0,77 & \multirow{7}{*}{2,88} & \multirow{7}{*}{6} & \multirow{7}{*}{$\mathbf{0 , 0 1 0}$} \\
\hline & De 1 a 3 anos & 70 & 3,01 & 0,72 & & & \\
\hline & De 4 a 8 anos & 79 & 2,84 & 0,85 & & & \\
\hline & De 9 a 13 anos & 43 & 2,94 & 0,82 & & & \\
\hline & De 14 a 19 anos & 4 & 2,65 & 0,84 & & & \\
\hline & De 20 a 30 anos & 10 & 3,48 & 1,01 & & & \\
\hline & Acima de 30 anos & 6 & 3,40 & 1,22 & & & \\
\hline \multirow{7}{*}{$\begin{array}{l}\text { Avaliação de } \\
\text { Desempenho e } \\
\text { Competências }\end{array}$} & Menos de 1 ano & 26 & 3,56 & 0,83 & \multirow{7}{*}{2,48} & \multirow{7}{*}{6} & \multirow{7}{*}{$\mathbf{0 , 0 2 4}$} \\
\hline & De 1 a 3 anos & 70 & 2,97 & 0,97 & & & \\
\hline & De 4 a 8 anos & 79 & 3,07 & 0,89 & & & \\
\hline & De 9 a 13 anos & 43 & 3,09 & 1,06 & & & \\
\hline & De 14 a 19 anos & 4 & 3,85 & 1,11 & & & \\
\hline & De 20 a 30 anos & 10 & 3,64 & 1,20 & & & \\
\hline & Acima de 30 anos & 6 & 3,70 & 0,86 & & & \\
\hline \multirow{7}{*}{$\begin{array}{l}\text { Remuneração e } \\
\text { Recompensas }\end{array}$} & Menos de 1 ano & 26 & 3,15 & 0,82 & \multirow{7}{*}{2,54} & \multirow{7}{*}{6} & \multirow{7}{*}{$\mathbf{0 , 0 2 1}$} \\
\hline & De 1 a 3 anos & 70 & 2,60 & 0,91 & & & \\
\hline & De 4 a 8 anos & 79 & 2,47 & 0,91 & & & \\
\hline & De 9 a 13 anos & 43 & 2,61 & 1,03 & & & \\
\hline & De 14 a 19 anos & 4 & 2,63 & 0,66 & & & \\
\hline & De 20 a 30 anos & 10 & 3,28 & 1,31 & & & \\
\hline & Acima de 30 anos & 6 & 2,83 & 1,02 & & & \\
\hline
\end{tabular}

Fonte: dados da pesquisa

A partir dos resultados constantes na Tabela 13, observa-se que há diferença significativa entre as médias dos respondentes, a partir da variável tempo de serviço no órgão, para as políticas de Recrutamento e Seleção, Envolvimento, Condições de Trabalho, Avaliação de Desempenho e Competências e Remuneração e Recompensas. Os valores da ANOVA para o fator Recrutamento e Seleção foi de $F(6,231)=2,78, p=0,013, \omega^{2}=0,04$, para o fator Envolvimento $F(6,231)=3,35, p=0,004, \omega^{2}=0,06$, para Condições de Trabalho $F(6,231)=2,88, p=0,010, \omega^{2}=0,04$, para Avaliação de Desempenho e Competências foi de $F(6,231)=2,48, p=0,024, \omega^{2}=0,04$, e para o fator Remuneração e Recompensas o valor da ANOVA foi de $F(6,231)=2,54, p=0,02, \omega^{2}=0,04$. 
Com objetivo de identificar para qual ou quais categorias as diferenças de médias foram significativas, realizou-se o teste Post Hoc - Tukey, com intervalo de confiança de $95 \%$ ( $\mathrm{p}<0,05)$, conforme apresentado na tabela abaixo:

Tabela 14. Resultado do teste Post Hoc/Tukey - EPPRH/Tempo de serviço no órgão

\begin{tabular}{|c|c|c|c|c|c|}
\hline Fator & $\begin{array}{l}\text { Tempo de serviço } \\
\text { no órgão (I) }\end{array}$ & $\begin{array}{c}\text { Tempo de serviço } \\
\text { no órgão }(J)\end{array}$ & $\begin{array}{c}\text { Mean Difference } \\
(I-J)\end{array}$ & $\begin{array}{c}\text { Std. } \\
\text { Error }\end{array}$ & $\mathbf{p}$ \\
\hline \multirow{2}{*}{$\begin{array}{l}\text { Recrutamento e } \\
\text { Seleção }\end{array}$} & \multirow{2}{*}{ Menos de 1 ano } & De 1 a 3 anos & 0,65 & 0,22 & $\mathbf{0 , 0 4 3}$ \\
\hline & & De 4 a 8 anos & 0,73 & 0,21 & $\mathbf{0 , 0 1 1}$ \\
\hline \multirow{2}{*}{ Envolvimento } & \multirow{2}{*}{ Menos de 1 ano } & De 4 a 8 anos & 0,90 & 0,22 & 0,001 \\
\hline & & De 9 a 13 anos & 0,79 & 0,24 & $\mathbf{0 , 0 1 7}$ \\
\hline $\begin{array}{l}\text { Condições de } \\
\text { Trabalho }\end{array}$ & Menos de 1 ano & De 4 a 8 anos & 0,63 & 0,19 & $\mathbf{0 , 0 1 4}$ \\
\hline $\begin{array}{l}\text { Remuneração e } \\
\text { Recompensas }\end{array}$ & Menos de 1 ano & De 4 a 8 anos & 0,68 & 0,21 & $\mathbf{0 , 0 2 5}$ \\
\hline
\end{tabular}

Fonte: dados da pesquisa

Com base no resultado do teste Post Hoc, pode-se inferir que os servidores com menos de 1 ano de tempo de serviço no órgão $(\mathrm{M}=3,79, \mathrm{DP}=0,70)$ são menos indiferentes com relação à política de Recrutamento e Seleção do que os servidores que estão de 1 a 3 anos $(\mathrm{M}=3,14, \mathrm{DP}=0,91)$ e de 4 a 8 anos no órgão $(\mathrm{M}=3,06, \mathrm{DP}=1,04)$. Essa diferença significativa da percepção dos servidores com menos de 1 ano no órgão se repetiu nas demais políticas constantes na Tabela 13. Na política de Envolvimento, os servidores que estão de 4 a 8 anos $(\mathrm{M}=2,54, \mathrm{DP}=0,94)$ e de 9 a 13 anos no órgão $(\mathrm{M}=2,65, \mathrm{DP}=1,10)$ não percebem ou discordam com a referida política. Já os servidores com menos de 1 ano no órgão $(M=3,44$, $\mathrm{DP}=0,74)$ são indiferentes com as atuais práticas.

Nas políticas de Condições de Trabalho e Remuneração e Recompensas, a percepção dos servidores com menos de 1 ano no órgão $(\mathrm{M}=3,47, \mathrm{DP}=0,77 ; \mathrm{M}=3,15, \mathrm{DP}=0,82$, respectivamente) se diferenciou significativamente somente da percepção dos servidores que estão de 4 a 8 anos no órgão ( $\mathrm{M}=2,84, \mathrm{DP}=0,85 ; \mathrm{M}=2,47, \mathrm{DP}=0,91$, respectivamente), demonstrando que os servidores com menos de 1 ano no órgão são indiferentes com relação à referida política e os servidores que estão de 4 a 8 anos não a percebem ou discordam das práticas vigentes. Para a política de Avaliação de Desempenho e Competências, não foi possível identificar qual ou quais categorias tiveram diferenças de médias significativas, por meio do primeiro teste Post Hoc. Dessa forma, optou-se por manter a primeira categoria (menos de 1 ano), agrupar as faixas de 1 a 3 anos, de 4 a 8 anos e de 9 a 13 anos de tempo de serviço no órgão e criar uma segunda categoria, e, por fim, agrupar as faixas de 14 a 19 anos, de 20 a 30 anos e acima de 30 anos, criando a terceira categoria de tempo de serviço no órgão, para que fosse realizada uma nova análise ANOVA. 
Os resultados da nova análise confirmaram a diferença significativa existente entre as médias dos respondentes, a partir da variável tempo de serviço no órgão, para a política de Avaliação de Desempenho e Competências $\left(F(2,235)=7,18, p=0,001, \omega^{2}=0,04\right)$, confirmando a primeira análise. Assim, procedeu-se um novo teste Post Hoc para identificar qual ou quais categorias as diferenças de médias foram significativas, conforme apresentado na tabela a seguir:

Tabela 15. Resultado do teste Post Hoc/Tukey - EPPRH/Tempo de serviço no órgão - após alteração

\begin{tabular}{cccccc}
\hline Fator & $\begin{array}{c}\text { Tempo de serviço } \\
\text { no órgão (I) }\end{array}$ & $\begin{array}{c}\text { Tempo de serviço } \\
\text { no órgão (J) }\end{array}$ & $\begin{array}{c}\text { Mean } \\
\text { Difference }(\text { I-J) }\end{array}$ & $\begin{array}{c}\text { Std. } \\
\text { Error }\end{array}$ & p \\
\hline Avaliação de & Menos de 1 ano & De 1 a 13 anos & 0,53 & 0,20 & $\mathbf{0 , 0 2 3}$ \\
Desempenho & De 14 anos ou acima & & 0,66 & 0,22 & $\mathbf{0 , 0 0 9}$ \\
\hline
\end{tabular}

Nota: $p<0,05$

Fonte: dados da pesquisa

O resultado do teste Post Hoc revelou que os servidores que tem menos de 1 ano no órgão $(\mathrm{M}=3,56, \mathrm{DP}=0,83)$ e os que estão a pelo menos 14 anos ou acima $(\mathrm{M}=3,70, \mathrm{DP}=1,04)$ são menos indiferentes, com relação à política de Avaliação de Desempenho e Competências, do que os servidores que estão no órgão de 1 a 13 anos $(\mathrm{M}=3,04, \mathrm{DP}=0,96)$.

Essa diferença significativa encontrada em praticamente todas as políticas, com relação à percepção dos servidores com menos de 1 ano no órgão e os servidores que estão de 4 a 13 anos no órgão, pode ser justificada em virtude do pouco tempo que se passou após terem sido informados sobre as políticas de gestão de pessoas existentes no órgão. Dessa forma, talvez os referidos servidores, com menos de 1 ano no órgão, não tenham inclusive participado ou usufruído dessas políticas, em virtude do pouco tempo que estão em exercício, e devido a isso preferiram ser indiferentes no julgamento.

A seguir, são apresentados os resultados da ANOVA em relação ao fator unidimensional da EICCO com a variável sociodemográfica (idade) que obteve diferença significativa entre as médias.

Tabela 16. ANOVA da variável idade com o fator da EICCO

\begin{tabular}{clcccccc}
\hline Fator & \multicolumn{1}{c}{ Idade } & N & Média & $\begin{array}{c}\text { Desvio- } \\
\text { Padrão }\end{array}$ & F & df & p \\
\hline \multirow{3}{*}{ Comprometimento } & De 21 a 30 anos & 67 & 1,29 & 0,83 & & & \\
Organizacional 31 a 40 anos & 90 & 1,38 & 0,82 & & & \\
& De 41 a 50 anos & 40 & 1,47 & 0,91 & $\mathbf{2 , 6 0}$ & 4 & $\mathbf{0 , 0 3 7}$ \\
& De 51 a 60 anos & 38 & 1,78 & 0,94 & & & \\
\hline & Acima de 60 anos & 4 & 2,00 & 0,34 & & & \\
\hline
\end{tabular}

Fonte: dados da pesquisa

Ao analisar a Tabela 16, verifica-se que a ANOVA da relação mostrou que há diferenças significativas entre as faixas etárias da variável idade e o fator de intenções 
comportamentais de Comprometimento Organizacional. O resultado da ANOVA para o referido fator foi de $F(4,234)=2,60, p=0,037, \omega^{2}=0,03$. Com objetivo de identificar para qual ou quais categorias as diferenças de médias foram significativas, realizou-se o teste Post Hoc - Tukey, com intervalo de confiança de 95\%, conforme demonstrado na tabela abaixo:

Tabela 17. Resultado do teste Post Hoc/Tukey - EICCO/Idade

\begin{tabular}{cccccc}
\hline Fator & Idade (I) & Idade (J) & $\begin{array}{c}\text { Mean } \\
\text { Difference (I-J) }\end{array}$ & $\begin{array}{c}\text { Std. } \\
\text { Error }\end{array}$ & p \\
\hline $\begin{array}{c}\text { Comprometimento } \\
\text { Organizacional }\end{array}$ & De 51 a 60 anos & De 21 a 30 anos & 0,49 & 0,17 & $\mathbf{0 , 0 4 0}$ \\
\hline
\end{tabular}

Nota: $p<0,05$

Fonte: dados da pesquisa

A partir do resultado do teste Post Hoc, verifica-se que a média dos respondentes com idade entre 21 a 30 anos $(M=1,29, D P=0,83)$ foi significativamente mais baixa do que os que estão nas faixas etárias de 51 a 60 anos $(\mathrm{M}=1,78, \mathrm{DP}=0,94)$. Assim, pode-se inferir que as intenções comportamentais de comprometimento organizacional dos servidores com idade entre 21 a 30 anos são menores do que aqueles que estão na faixa etária de 51 a 60 anos. Esse resultado pode ser em virtude do servidor de mais idade ter mais tempo de serviço no órgão e, devido a isso, ter estabelecido um vínculo afetivo com a organização.

Por fim, ressalta-se que não foram encontradas diferenças significativas entre a variável demográfica "escolaridade" e a variável funcional "carreira" em relação aos fatores da EPPRH, bem como entre a variável demográfica "escolaridade" e as variáveis funcionais "unidade de lotação", "carreira" e "tempo de serviço no órgão" com a EICCO, em sua estrutura unidimensional.

A seguir, são apresentados os resultados do teste t, para amostras independentes, que obtiveram diferenças significativas entre as médias, em relação aos fatores da EPPRH e ao fator unidimensional da EICCO e a variável profissional (ocupação de cargo em comissão).

Tabela 18. Teste t da variável ocupação de cargo em comissão com os fatores da EPPRH

\begin{tabular}{|c|c|c|c|c|c|c|c|}
\hline Fator & $\begin{array}{l}\text { Ocupa cargo } \\
\text { em comissão }\end{array}$ & $\mathbf{N}$ & Média & $\begin{array}{l}\text { Desvio- } \\
\text { Padrão }\end{array}$ & $\mathbf{t}$ & df & $\mathbf{p}$ \\
\hline \multirow{2}{*}{ Envolvimento } & Sim & 58 & 3,07 & 0,96 & \multirow{2}{*}{2,55} & \multirow{2}{*}{230} & \multirow{2}{*}{0,011} \\
\hline & Não & 174 & 2,70 & 0,98 & & & \\
\hline \multirow{2}{*}{ TD\&E } & Sim & 58 & 3,64 & 0,99 & \multirow{2}{*}{2,77} & \multirow{2}{*}{230} & \multirow{2}{*}{0,006} \\
\hline & Não & 174 & 3,20 & 1,05 & & & \\
\hline Condições de & Sim & 58 & 3,21 & 0,77 & \multirow{2}{*}{2,09} & \multirow{2}{*}{230} & \multirow{2}{*}{$\mathbf{0 , 0 3 8}$} \\
\hline Trabalho & Não & 174 & 2,94 & 0,85 & & & \\
\hline Remuneração e & Sim & 58 & 3,11 & 0,89 & \multirow{2}{*}{4,41} & \multirow{2}{*}{230} & \multirow{2}{*}{$<0,001$} \\
\hline Recompensas & Não & 174 & 2,50 & 0,93 & & & \\
\hline
\end{tabular}

Fonte: dados da pesquisa 
Ao analisar a Tabela 18, observa-se que há diferença significativa entre as médias dos respondentes, a partir da variável ocupação de cargo em comissão, para as políticas de Envolvimento, TD\&E, Condições de Trabalho e Remuneração e Recompensas. O teste t, para amostras independentes, da política de Envolvimento resultou no valor de $t(230)=2,55, p=$ 0,011, $r=0,16$, da política de TD\&E o resultado foi de $t(230)=2,77, p=0,006, r=0,18$, já na política de Condições de Trabalho foi de $t(230)=2,09, p=0,038, r=0,14$, e, por fim, na política de Remuneração e Recompensas o resultado foi de $t(230)=4,41, p<0,001, r=0,28$.

Dessa forma, verifica-se que a média dos respondentes que ocupam cargo em comissão foi significativamente mais alta do que aqueles que não ocupam, em relação às políticas constantes na Tabela 18. Assim, pode-se inferir que os servidores que não ocupam cargo em comissão não percebem as políticas de Envolvimento, TD\&E, Condições de Trabalho e Remuneração e Recompensas, e os servidores que ocupam cargo em comissão demonstraram indiferença com relação às referidas políticas.

Tabela 19. Teste t da variável ocupação de cargo em comissão com o fator da EICCO

\begin{tabular}{cccccccc}
\hline Fator & $\begin{array}{c}\text { Ocupa cargo } \\
\text { em comissão }\end{array}$ & $\mathbf{N}$ & Média & $\begin{array}{c}\text { Desvio- } \\
\text { Padrão }\end{array}$ & $\mathbf{t}$ & $\mathbf{d f}$ & $\mathbf{p}$ \\
\hline $\begin{array}{c}\text { Comprometimento } \\
\text { Organizacional }\end{array}$ & Sim & 58 & 1,62 & 0,89 & $\mathbf{1 , 9 8}$ & 230 & $\mathbf{0 , 0 4 9}$ \\
\hline
\end{tabular}

Fonte: dados da pesquisa

A partir dos resultados constantes na Tabela 19, observa-se que há diferença significativa entre as médias dos respondentes, a partir da variável ocupação de cargo em comissão, para o fator comprometimento organizacional. O teste t, para amostras independentes, do referido fator resultou no valor de $t(230)=1,98, p=0,049, r=0,13$. Dessa forma, verifica-se que a média dos respondentes que ocupam cargo em comissão foi relativamente mais alta do que aqueles que não ocupam, em relação às intenções comportamentais de comprometimento organizacional. Assim, pode-se inferir que as intenções comportamentais de comprometimento organizacional dos servidores que não ocupam cargo em comissão no MMA são menores do que aqueles que ocupam.

Essa diferença significativa encontrada tanto no resultado do teste t para os fatores da EPPRH, quanto para o fator da EICCO, que demonstram a indiferença dos servidores que ocupam cargo em comissão no MMA, pode ser em virtude do caráter precário da ocupação do cargo em comissão, que é de livre nomeação e exoneração, o que talvez tenha impossibilitado o julgamento sincero com relação aos itens da presente pesquisa. 
Por fim, ressalta-se que não foram encontradas diferenças significativas entre a variável demográfica "sexo" e a variável funcional "participação em programas de incentivos" em relação aos fatores da EPPRH e ao fator da EICCO.

\subsection{Modelagem por Equações Estruturais para o relacionamento entre as variáveis}

Nesta seção, são apresentados os resultados da Modelagem por Equações Estruturais (MEE). A MEE foi utilizada com objetivo de verificar os efeitos de políticas e práticas de gestão de pessoas sobre o comprometimento organizacional dos servidores do Ministério do Meio Ambiente (MMA), respondendo-se, assim, à pergunta de pesquisa e atendendo-se ao objetivo geral do presente estudo. De acordo com Hair et al. (2009), a vantagem de utilização da MEE, como uma técnica de análise multivariada, é a possibilidade de combinar aspectos da regressão múltipla e da análise fatorial para estimar uma série de relações de dependência simultaneamente.

Inicialmente foram analisadas as cargas fatoriais do modelo de mensuração proposto, resultantes da Análise Fatorial Confirmatória, com objetivo de obter índices válidos para a presente pesquisa. Foi utilizada, como parâmetro, a indicação de Hair et al. (2009), que sugere a eliminação de fatores com cargas inferiores a 0,40. Dessa forma, não foi necessário eliminar nenhum dos fatores, uma vez que todas as cargas fatoriais apresentaram valores acima de 0,40 , conforme se observa na tabela abaixo:

Tabela 20. Cargas fatoriais da EPPRH

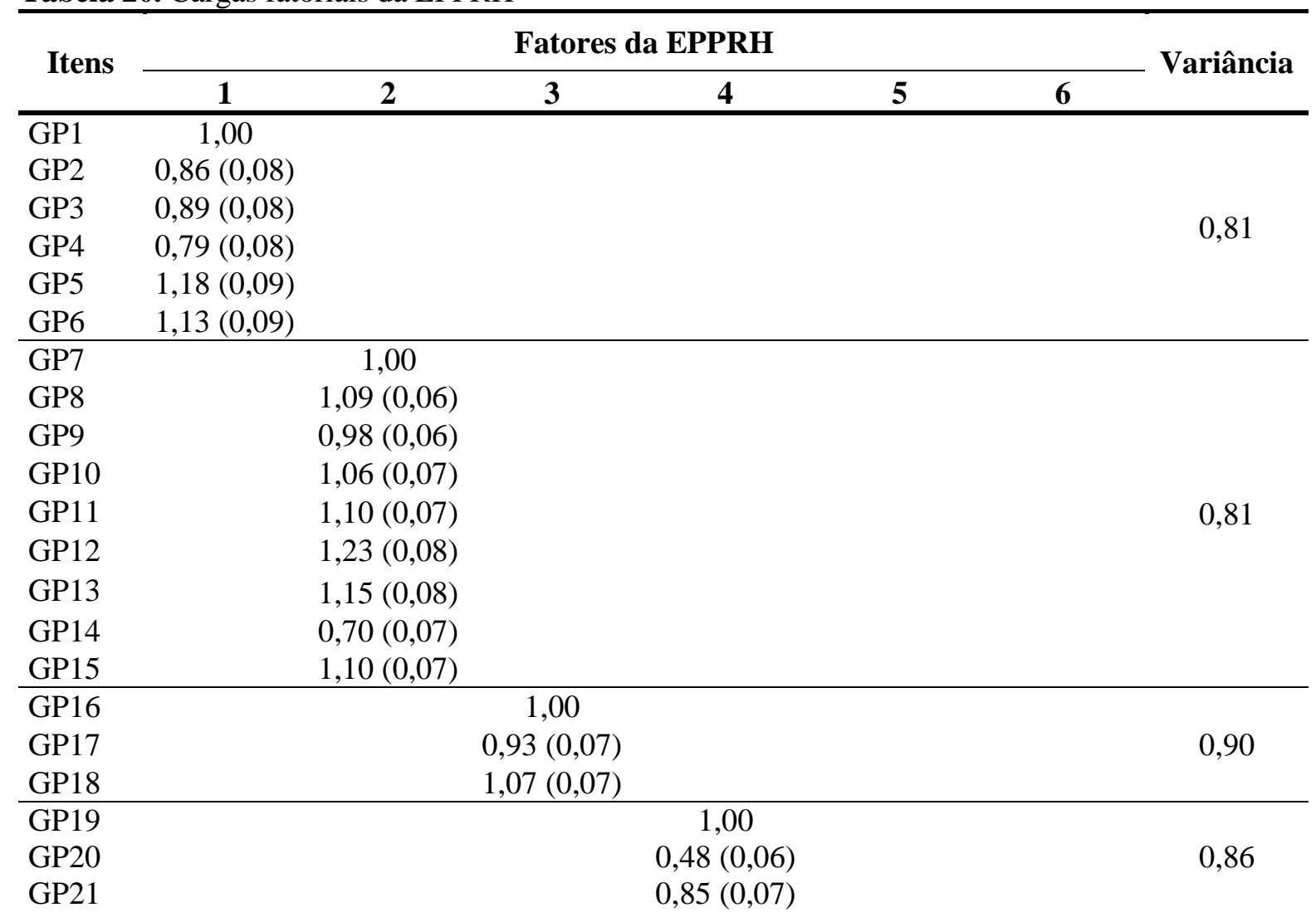




\begin{tabular}{lccc} 
GP22 & $0,59(0,07)$ & & \\
GP23 & $0,78(0,07)$ & & \\
\hline GP24 & $2,63(0,39)$ & \\
GP25 & $2,61(0,40)$ & \\
GP26 & $2,79(0,43)$ & \\
GP27 & $2,32(0,36)$ & \\
GP28 & & 1,00 & \\
\hline GP29 & & $1,48(0,16)$ & 0,41 \\
GP30 & $1,36(0,14)$ & \\
GP31 & & $1,06(0,15)$ & \\
GP32 & & & \\
\hline Nota:
\end{tabular}

Nota: denominação e definição dos fatores constam na Figura 11

Fonte: dados da pesquisa

Ao analisar os dados da Tabela 20, verifica-se que todas as variáveis observáveis (itens da escala) se relacionam fortemente com as respectivas variáveis latentes (seis fatores da EPPRH), indicando que a EPPRH é constituída pelos referidos fatores de forma homogênea, sem a predominância de nenhum deles.

Tabela 21. Cargas Fatoriais da EICCO

\begin{tabular}{lcc}
\hline \multicolumn{1}{c}{ Itens } & Fator da EICCO & $\begin{array}{c}\text { Variância dos } \\
\text { itens }\end{array}$ \\
\hline C5BCEO & 1,00 & 2.63 \\
C7BCEO & $0,99(0,12)$ & 0.99 \\
C11BCEO & $1,05(0,12)$ & 1.00 \\
C13BCEO & $1,15(0,15)$ & 1.82 \\
C16BCEO & $0,64(0,11)$ & 1.21 \\
C20BCEO & $1,20(0,14)$ & 1.55 \\
C2BCEO & $0,85(0,12)$ & 1.65 \\
C6BCEO & $1,11(0,15)$ & 2.36 \\
C8BCEO & $1,32(0,18)$ & 2.16 \\
C15BCEO & $0,89(0,18)$ & 1.26 \\
C18BCEO & $0,81(0,17)$ & 3.64 \\
C1BCEO & $1,20(0,17)$ & 3.74 \\
C3BCEO & $0,95(0,15)$ & 2.32 \\
C9BCEO & $0,76(0,11)$ & 1.00 \\
C10BCEO & $1,14(0,15)$ & 1.56 \\
C14BCEO & $1,06(0,17)$ & 1.59 \\
C19BCEO & $0,66(0,12)$ & 2.11 \\
C4BCEO & $0,85(0,13)$ & 1.82 \\
C12BCEO & $0,98(0,14)$ & 1.53 \\
C17BCEO & $1,15(0,15)$ & 2.23 \\
\hline Font:
\end{tabular}

Fonte: dados da pesquisa

Da mesma forma que a EPPRH, os itens da EICCO apresentaram cargas fatoriais satisfatórias (acima de 0,40), ou seja, todas as variáveis observáveis se relacionam fortemente com a respectiva variável latente, indicando que a EICCO é constituída pelos referidos itens de forma homogênea, sem a predominância de nenhum deles. A análise do modelo de mensuração permite verificar se os itens utilizados para medir os construtos ou fatores são 
significativos, e se realmente medem aquilo que se pretende medir. Ou seja, o modelo de mensuração verifica a validade do construto, permitindo avaliar, inicialmente, se cada construto tem confiabilidade satisfatória para, em seguida, serem estimadas as relações causais constantes do modelo estrutural (Hair et al., 2009).

Antes de iniciar a análise do modelo estrutural, se faz necessário verificar o ajuste do modelo. A Tabela 22 apresenta os resultados dos índices de ajuste utilizados na presente pesquisa. Como se verifica, o modelo obteve um bom ajuste no que tange aos índices $\chi^{2}$, RMSEA, AIC e BIC, os índices CFI e TLI ficaram um pouco abaixo do limite inferior desejável. O índice RMSEA resultou em 0,053 dentro do intervalo de 0,050 a 0,057 ( $\mathrm{p}<$ 0,05), demonstrando um bom ajuste do modelo à matriz dos dados. Sobre os resíduos, o SRMR resultou em um valor abaixo de 1,0, que é considerado positivo, embora esse índice não possua um teste estatístico que estabeleça um ponto de corte.

Tabela 22. Resultados dos índices de ajuste do modelo

\begin{tabular}{ccccccc}
\hline \multicolumn{7}{c}{ Índices de ajuste do modelo } \\
\hline Qui-quadrado $\left(\chi^{2}\right)$ & CFI & RMSEA & TLI/NNFI & AIC & BIC & SRMR \\
\hline $2122,590 * * *$ & 0,829 & 0,053 & 0,820 & 39883,057 & 40501,329 & 0,068 \\
\hline
\end{tabular}

Nota: $* * * \mathrm{P}<0,001$

Fonte: dados da pesquisa

Nesse sentido, após verificar a validade dos instrumentos utilizados e o ajuste do modelo, passa-se a analisar os resultados do modelo estrutural, tendo como variáveis exógenas as políticas e práticas de gestão de pessoas (Recrutamento e Seleção, Envolvimento, TD\&E, Condições de Trabalho, Avaliação de Desempenho e Competências e Remuneração e Recompensas), e variável endógena o comprometimento organizacional, em sua estrutura unidimensional. A figura a seguir, apresenta o modelo estrutural da MEE com os seus respectivos resultados: 


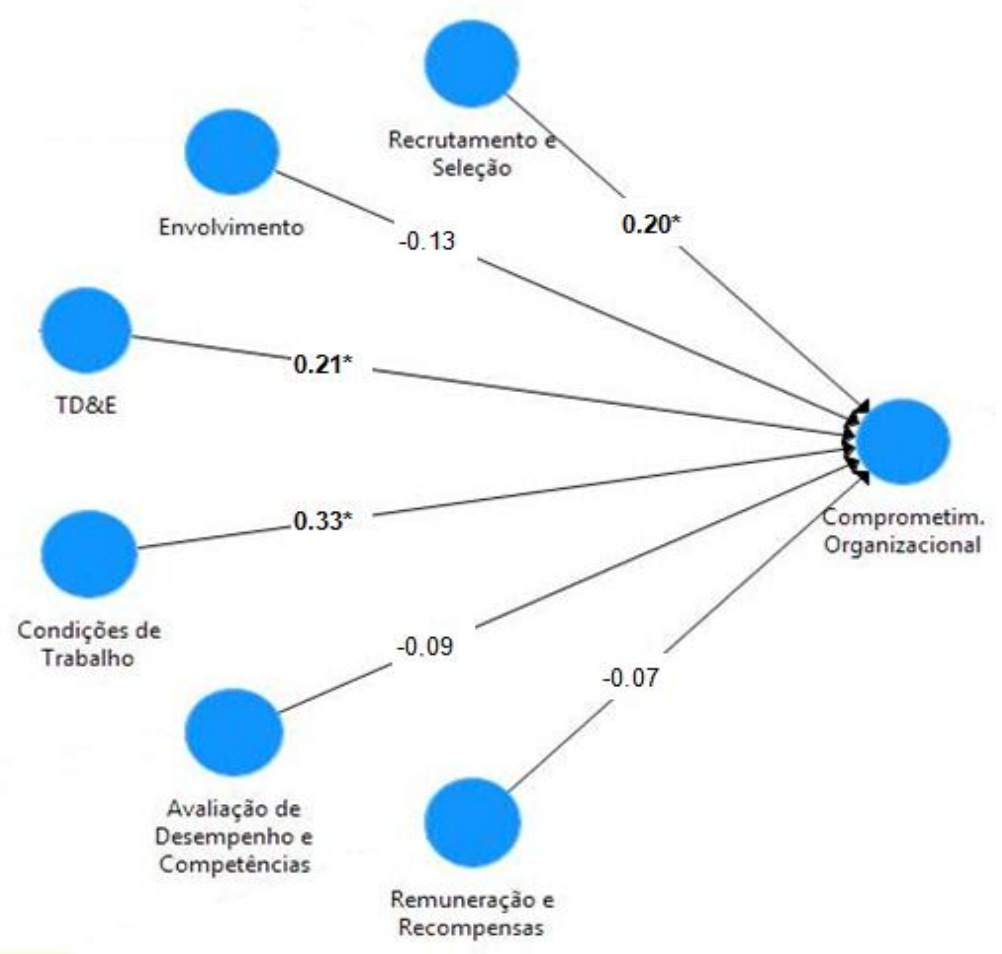

Figura 18. Resultados da MEE

Fonte: dados da pesquisa

A partir dos resultados constantes na Figura 17, constata-se que há efeitos positivos em relação algumas políticas e práticas de gestão sobre o comprometimento organizacional dos servidores do MMA. As políticas de Recrutamento e Seleção $(\beta=0,20)$, Treinamento, Desenvolvimento e Educação (TD\&E) $(\beta=0,21)$ e Condições de Trabalho $(\beta=0,33)$ são preditoras do comprometimento organizacional dos servidores do MMA, indicando que, quanto mais os servidores percebem as referidas políticas, maior será a intenção comportamental de comprometimento organizacional.

Observa-se que a política que mais se destacou entre as preditoras do comprometimento organizacional dos servidores do MMA foi a de Condições de Trabalho, que se traduz em práticas como incentivo à saúde e à qualidade de vida no trabalho, ambiente adequado e condições propícias para a manutenção do bem-estar físico, psíquico e mental dos indivíduos, não exposição excessiva a ruídos, substâncias tóxicas, ou excessivas horas de trabalho, prevenção de doenças relacionadas ao trabalho, dentre outras, conforme já destacado no presente estudo.

Esses achados possuem evidências teóricas e empíricas, como o estudo de Demo et al. (2013), que ao realizarem um estudo confirmatório, utilizando-se como comparação a pesquisa de Borges et al. (2006), objetivando confirmar que políticas de gestão de pessoas são preditoras do comprometimento organizacional e da satisfação no trabalho, verificaram que a 
política de condições de trabalho foi a mais percebida pelos colaboradores da empresa pesquisada, ou seja, há uma maior percepção por parte dos colaboradores quanto aos esforços da organização no sentido de promover a saúde, segurança e bem-estar no trabalho.

Outra pesquisa que corrobora o resultado do presente estudo foi a realizada por Cançado, Moraes e Silva (2006), que buscou relacionar as políticas de gestão de pessoas e o comprometimento organizacional, utilizando o modelo tridimensional de Meyer e Allen (1991), constatando que a maioria das políticas de gestão de pessoas, dentre elas a de TD\&E, influencia as dimensões do comprometimento afetivo e normativo.

A tabela 23 apresenta a matriz de covariância dos fatores da EPPRH.

Tabela 23. Matriz de covariância dos fatores da EPPRH

\begin{tabular}{ccccccc}
\hline \multirow{2}{*}{ Fatores } & \multicolumn{7}{c}{ Valores da covariância } \\
\cline { 2 - 7 } & $\mathbf{1}$ & $\mathbf{2}$ & $\mathbf{3}$ & $\mathbf{4}$ & $\mathbf{5}$ & $\mathbf{6}$ \\
\hline $\mathbf{1}$ & 1,00 & & & & & \\
$\mathbf{2}$ & 0.49 & 1 & & & & \\
$\mathbf{3}$ & 0.39 & 0.65 & 1 & & & \\
$\mathbf{4}$ & 0.36 & 0.69 & 0.63 & 1 & & \\
$\mathbf{5}$ & 0.21 & 0.25 & 0.21 & 0.26 & 1 & \\
$\mathbf{6}$ & 0.34 & 0.47 & 0.39 & 0.47 & 0.20 & 1 \\
\hline
\end{tabular}

Nota: denominação e definição dos fatores constam na Figura 11

Fonte: dados da pesquisa

Por fim, a resposta ao problema apresentado na presente pesquisa é que há efeitos positivos em relação a algumas políticas e práticas de gestão sobre o comprometimento organizacional dos servidores do MMA, e as políticas de Recrutamento, TD\&E e Condições de Trabalho são antecedentes do comprometimento organizacional dos servidores do MMA, já que foi possível verificar forte relação de predição entre as variáveis, conforme demonstrado na Figura 17. Assim, pode-se afirmar que a hipótese da pesquisa foi parcialmente confirmada, demonstrando que no contexto da organização objeto de estudo, os servidores tendem a demonstrar intenção de comprometimento ao perceberem que a organização tende a oferecer condições adequadas de trabalho, bem como atrair e desenvolver pessoas para o desempenho adequado no trabalho. 


\section{CONCLUSÕES E RECOMENDAÇÕES}

O comportamento humano nas organizações é um fenômeno extremamente complexo e ainda necessita de muitos estudos para a sua compreensão. Indo ao encontro desta necessidade, o presente estudo teve o propósito de responder a seguinte pergunta: "quais efeitos de políticas e práticas de gestão de pessoas sobre o comprometimento organizacional dos servidores do Ministério do Meio Ambiente (MMA)?”.

Para responder essa pergunta foram traçados alguns objetivos. O primeiro objetivo do estudo foi identificar a percepção dos servidores acerca das políticas e práticas de gestão de pessoas do MMA. Tal objetivo foi plenamente atingido com os resultados da análise descritiva da Escala de Políticas e Práticas de Recursos Humanos (EPPRH), que, em suma, verificou que os servidores do MMA não percebem nenhuma das políticas e práticas de gestão de pessoas do órgão, uma vez que a maior média entre os fatores foi da política de Treinamento, Desenvolvimento e Educação (TD\&E), mas, ainda assim, o resultado demonstrou indiferença dos respondentes com a referida política.

O segundo objetivo era o de identificar a intenção comportamental dos servidores do MMA em relação ao comprometimento organizacional. Nesse sentido, constatou-se que a postura dos servidores do MMA indica intenção comportamental de baixo comprometimento organizacional. Nenhum dos itens da escala aplicada alcançou média superior a 4,9, que caracterizaria uma postura proativa, indicando o comprometimento organizacional.

Por fim, buscou-se verificar a influência dos dados sociodemográficos e profissionais nos dois construtos estudados (percepção de políticas e práticas de gestão de pessoas e intenções comportamentais de comprometimento organizacional). Constatou-se que os servidores com idade acima de 51 anos são mais indiferentes com relação à política de Envolvimento do que os que estão na faixa etária de 41 a 50 anos. Outra diferença significativa encontrada foi entre a percepção dos servidores lotados na Subsecretaria de Planejamento, Orçamento e Administração (SPOA/SECEX) e servidores lotados em outras unidades, com relação às políticas de Envolvimento, Treinamento, Desenvolvimento e Educação (TD\&E), Condições de Trabalho e Remuneração e Recompensas.

Os servidores lotados na SPOA/SECEX demonstraram uma maior percepção em relação à política de TD\&E do que os servidores lotados em outras unidades, como Gabinete da Ministra, Secretaria de Biodiversidade e Florestas - SBF, Secretaria e Extrativismo e Desenvolvimento Rural Sustentável - SEDR, dentre outras. Com relação às políticas de Envolvimento, Condições de Trabalho e Remuneração e Recompensas, os servidores da 
SPOA/SECEX se mostraram indiferentes, enquanto os outros servidores, na maioria dos casos, responderam que não percebem as políticas.

Ainda com relação ao último objetivo específico, foi possível identificar uma diferença significativa da percepção dos servidores com menos de 1 ano no órgão e os servidores que estão de 4 a 13 anos no órgão, com relação às políticas de Recrutamento e Seleção, Envolvimento, Condições de Trabalho e Remuneração e Recompensas. Os servidores que estão com menos de 1 ano no órgão, na maioria dos casos, são indiferentes às atuais práticas. E os servidores que estão entre 4 e 13 anos no órgão responderam que não percebem as referidas políticas. Com relação ao construto comprometimento organizacional, constatou-se que os servidores com idade entre 21 a 30 anos apresentam menos intenções comportamentais de comprometimento organizacional do que aqueles que estão na faixa etária de 51 a 60 anos.

Após o atingimento dos objetivos específicos traçados, foi possível responder ao problema de pesquisa, utilizando a Modelagem por Equações Estruturais (MEE). Os resultados encontrados apontaram que as políticas de Recrutamento e Seleção $(\beta=0,20)$, TD\&E $(\beta=0,21)$ e Condições de Trabalho $(\beta=0,33)$ são preditoras do Comprometimento Organizacional dos servidores do MMA, indicando que, quanto mais os servidores percebem as referidas políticas, maior será a intenção comportamental de comprometimento organizacional.

Nesse sentido, o que pode ser extraído desse resultado é que os gestores de pessoas, tanto de empresas privadas, como já demonstrado em estudos anteriores, quanto de organizações públicas, como o da presente pesquisa, que visam ter servidores mais comprometidos com a organização, devem estar atentos às políticas de Recrutamento, TD\&E e Condições de Trabalho, aprimorando as atuais práticas e agregando novas. Cabe ressaltar que uma estratégia de comprometimento assume como premissa a ideia de que todos os colaboradores são parceiros na gestão, o que implica a necessidade da organização desenvolver as capacidades e habilidades dos indivíduos, assim como implica a criação de sistemas de gestão de pessoas capazes de atuar efetivamente de acordo com as metas organizacionais (Mascarenhas, 2008).

Por outro lado, as demais políticas de gestão de pessoas, que não obtiveram resultado positivo na predição com o comprometimento organizacional (Envolvimento, Avaliação de Desempenho e Competências e Remuneração e Recompensas), não devem ser tratadas como irrelevantes, uma vez que a partir dessas políticas outros fatores do comportamento organizacional podem ser favorecidos, como a motivação, satisfação e bem estar no trabalho. 
Para os autores Mabey, Salaman e Storey (1998) as políticas de gestão de pessoas devem se basear nas seguintes premissas: a) valorização dos talentos e capacidades humanos; b) atração e manutenção de pessoas de alto potencial e qualificação; c) criação de condições favoráveis à motivação individual e à mobilização dos grupos em torno das metas organizacionais; d) criação de oportunidades de crescimento funcional e desenvolvimento profissional na própria organização; e) oferecimento de incentivos vinculados aos resultados organizacionais, de preferência com base na contribuição dos indivíduos e grupos; f) adaptação de políticas integradas de gestão de pessoas à realidade da organização e ao contexto externo econômico-social e político.

Boxall (1996) entende que a contribuição da gestão de pessoas deve ser avaliada pela sua capacidade de gerar e sustentar recursos estratégicos, desenvolver capacidades e competências organizacionais, criar organizações mais flexíveis e inteligentes, apresentando níveis superiores de cooperação, coordenação e inovação. Nesse sentido, o presente trabalho pode ser visto, para a organização pesquisada, como um diagnóstico, podendo ser utilizado pelos gestores públicos para compreender com mais profundidade como os servidores percebem as atuais políticas e práticas de gestão de pessoas e se as intenções comportamentais desses servidores refletem uma postura comprometida com a organização, bem como, entender as relações existentes entre esses dois construtos.

Com objetivo de indicar ou mesmo atualizar a agenda de pesquisa da área, recomendase, inicialmente, que estudos futuros utilizem dados longitudinais, uma vez que dados transversais podem comprometer a generalização dos resultados. Sugere-se, também, amostras de outras organizações públicas, com a mesma natureza, para que se possa realizar um estudo comparativo na administração pública federal direta, uma vez que não foram encontrados outros estudos, como este, nesse setor, que apresenta um contexto peculiar, em virtude do preceito constitucional da legalidade, que subordina qualquer forma de ação do agente público ao que está legalmente determinado.

Por fim, recomenda-se, ainda, trabalhar com uma amostra maior, uma vez que não se obteve a normalidade multivariada e ainda em virtude de dois índices do ajuste do modelo terem ficado um pouco abaixo do limite inferior desejável, o que enseja reespecificações e novos testes em estudos futuros. Outras variáveis também poderão ser integradas ao modelo, como desempenho organizacional, satisfação no trabalho e autonomia da área de gestão de pessoas. 


\section{REFERÊNCIAS}

Abbad, G. da S. (1994). Avaliação de Desempenho em Psicologia: questões conceituais e metodológicas. Psicologia: Teoria e Pesquisa, Brasil, 10(3), 355-374.

Aguinis, H. \& Kraiger, K. (2009). Benefits of training and development for individuals and teams, organizations, and Society. Annual Review of Psychology, 60, 451-474.

Albuquerque, L. G. (1999). Estratégias de recursos humanos e competitividade. In: M. M. F. Vieira \& L. M. B. Oliveira (Orgs), Administração contemporânea: perspectivas estratégicas. São Paulo: Atlas.

Amaral, H. K. (2006). Desenvolvimento de competências de servidores na administração pública brasileira. Revista do Serviço Público, 57(4), 549-563, outubro/dezembro.

Araújo, J. F. F. E. (2013). Da nova Gestão Pública à nova governação pública: pressões emergentes na Administração Pública. In: C. Madureira \& Asensio (Orgs.). Handbook de Administração Pública. Lisboa: INA Editora.

Bandeira, M. L., Marques, A. L \& Veiga, R. T. (1999). A ECT na trilha da modernidade: políticas de recursos humanos influenciando múltiplos comprometimentos. Anais do Encontro Nacional da Associação Nacional de Pós-Graduação e Pesquisa em Administração - EnANPAD. Foz do Iguaçu, PR, Brasil, 23.

Barbosa, L. (1996). Meritocracia à Brasileira: o que é desempenho no Brasil? Revista do Serviço Público. Brasília, 120(3), setembro/dezembro.

Bastos, A. V. B. (1993). Comprometimento organizacional: um balanço dos resultados e desafios que cercam essa tradição de pesquisa. Revista de Administração de Empresas, 33(3), 52-64, maio/junho.

Bastos, A. V. B. (1994). Múltiplos comprometimentos no trabalho: a estrutura dos vínculos do trabalhador com a organização, a carreira e o sindicato. $228 \mathrm{f}$. Tese (doutorado em Psicologia) - Universidade de Brasília, Brasília, Brasil.

Bastos, A. V. B e colaboradores (2008). Comprometimento Organizacional. In: M. M. M. Siqueira (Org.), Medidas de comprometimento organizacional: ferramentas de diagnóstico e de gestão. Porto Alegre: Artmed.

Bastos, A. V. B \& Borges-Andrade, J. E. (2002). Comprometimento com o trabalho: padrões em diferentes contextos organizacionais. Revista de Administração de Empresas, 42(2), 31-41, abril/junho.

Beck, K. \& Wilson, C. (2001). Have we studied, shoud we study, and can we study the development of commitment? Methodological issues and the developmental study of work-related commitment. Human Resource Management Review, 11, 257-278.

Bergue, S. T. (2007). Gestão da Remuneração em Organizações Públicas: Limites e Possibilidades para a Assimilação de Modelos do Setor Privado. . Anais do Encontro de Gestão de Pessoas e Relações de Trabalho-EnGPR. Natal, RN, Brasil, 1.

Bessi, V. G. (2011). Espaço-Temporalidade no cotidiano do trabalho contemporâneo. In: D. L. S. Ferraz, A. P. Oltramari \& O. Ponchirolli (orgs). Gestão de Pessoas e Relações de Trabalho. São Paulo: Atlas.

Bezerra, S. A. C. \& Helal, D. H. (2009). Os Desafios do recrutamento e seleção de docentes do curso superior de administração: um estudo em Belo Horizonte. Anais do Encontro 
Nacional da Associação Nacional de Pós-Graduação e Pesquisa em Administração EnANPAD. São Paulo, SP, Brasil, 33.

Blau, G. (2001). On assessing the construct validity of two multidimensional constructs: Occupational commitment and occupational entrenchment. Human Resource Management Review, 11, 279-298.

Blau, G. \& Holladay, E. B. (2006). Testing the discriminant validity of a four-dimensional occupational commitment measure. Journal of Occupational and Organizational Psychology, 79, 691-704.

Borges, R. S. G., Marques, A. L. \& Adorno, R. D. (2006). Investigando as relações entre Políticas de RH, Comprometimento Organizacional e Satisfação no Trabalho. RPA Brasil, $2,59-72$.

Borges-Andrade, J. E. \& Pilati, R. (2001). Comprometimento atitudinal e comportamental: relações com suporte e imagem nas organizações. Revista de Administração Contemporânea, Rio de Janeiro, 5(3), 85-105, setembro/dezembro.

Borges-Andrade, J. E. (2002). Desenvolvimento de medidas em avaliação de treinamento. Revista Estudos de Psicologia, 7(número especial), 31-43.

Botelho, R. D. \& Paiva, K. C. M. (2011). Comprometimento organizacional: um estudo no Tribunal de Justiça do Estado de Minas Gerais. Revista de Administração Pública, Rio de Janeiro, 45(5), 1249-1283, setembro/outubro.

Boxall, P. (1996). The strategic HRM debate and the resource-based view of the firm. Human Resource Management Journal, 6(3), 59-75.

Brandão, H. P. \& Guimarães, T. A. (2001). Gestão de competências e gestão de desempenho: tecnologias distintas ou instrumentos de um mesmo constructo? Revista de Administração de Empresas, 41(1), 08-15.

Brasil. Constituição da República Federativa do Brasil de 1988. (1988). Brasília. Recuperado em 16 de junho de 2014, de http://www.planalto.gov.br/ccivil_03/constituicao/ constituicaocompilado.htm.

Brasil. Decreto-Lei $n^{\circ}$ 200, de 25 de fevereiro de 1967. (1967). Dispõe sobre a organização da Administração Federal, estabelece diretrizes para a Reforma Administrativa, e dá outras providências. Brasília. Recuperado em 26 de junho de 2014, de http://www.planalto.gov.br/ccivil_03/decreto-lei/del0200.htm.

Brasil. Decreto $n$ 5.707, de 23 de fevereiro de 2006. (2006). Institui a Política e as Diretrizes para o Desenvolvimento de Pessoal da administração pública federal direta, autárquica e fundacional, e regulamenta dispositivos da Lei no 8.112, de 11 de dezembro de 1990. Brasília. Recuperado em 16 de junho de 2014, de http://www.planalto.gov.br/ccivil_03/_Ato2004-2006/2006/Decreto/D5707.htm.

Brasil. Decreto $n^{\circ}$ 6.101, de 26 de abril de 2007. (2007). Aprova a estrutura regimental e o quadro demonstrativo dos cargos em comissão e das funções gratificadas do ministério do meio ambiente, e dá outras providências. Recuperado em 06 de novembro de 2014, de http://www.planalto.gov.br/ccivil_03/_Ato2007-2010/2007/Decreto/D6101.htm.

Brasil. Decreto $n^{\circ}$ 7.133, de 19 de março de 2010. (2010). Regulamenta os critérios e procedimentos gerais a serem observados para a realização das avaliações de desempenho individual e institucional e o pagamento das gratificações de desempenho de algumas carreiras e planos de cargos especiais do Poder Executivo Federal. Recuperado em 24 de 
abril de 2015, de http://www.planalto.gov.br/ccivil_03/_ato20072010/2010/Decreto/D7133.htm.

Brasil. Decreto $n^{\circ} 8.189$, de 21 de janeiro de 2014. (2014). Aprova a Estrutura Regimental e o Quadro Demonstrativo dos Cargos em Comissão e das Funções Gratificadas do Ministério do Planejamento, Orçamento e Gestão e remaneja cargos em comissão e funções comissionadas técnicas. Recuperado em 10 de junho de 2015, de http://www.planalto.gov.br/ccivil_03/_ato2011-2014/2014/Decreto/D8189.htm.

Brasil. Decreto $n^{o} 8.423$, de 30 de março de 2015. (2015). Regulamenta os critérios e procedimentos para a progressão e promoção na Carreira de Especialista em Meio Ambiente de que trata a Lei $\mathrm{n}^{\mathrm{o}} 10.410$, de 11 de janeiro de 2002. Brasília. Recuperado em 09 de abril de 2015, de http://www.planalto.gov.br/ccivil_03/_Ato20152018/2015/Decreto/D8423.htm.

Brasil. Lei $n^{o}$ 8.112, de 11 de dezembro de 1990. (1990). Dispõe sobre o regime jurídico dos servidores públicos civis da União, das autarquias e das fundações públicas federais. Brasília. Recuperado em 23 de abril de 2015, de http://www.planalto.gov.br/ccivil_03/leis/18112cons.htm.

Brasil. Lei $n^{o}$ 10.410, de 11 de janeiro de 2002. (2002). Cria e disciplina a carreira de Especialista em Meio Ambiente. Brasília. Recuperado em 06 de novembro de 2014, de http://www.planalto.gov.br/ccivil_03/leis/2002/L10410.htm.

Brasil. Lei $n^{o}$ 11.357, de 19 de outubro de 2006. (2006). Dispõe sobre a criação do Plano Geral de Cargos do Poder Executivo - PGPE e do Plano Especial de Cargos do Ministério do Meio Ambiente e do Instituto Brasileiro do Meio Ambiente e dos Recursos Naturais Renováveis - IBAMA - PECMA, e dá outras providências. Brasília. Recuperado em 06 de novembro de 2014, de https://www.planalto.gov.br/ccivil_03/_Ato20042006/2006/Lei/L11357.htm.

Brasil. Lei $n^{o}$ 12.778, de 28 de dezembro de 2013. (2013). Dispõe sobre remuneração e reajuste de Planos de Cargos, Carreiras e Planos Especiais de Cargos do Poder Executivo federal, e dá outras providências. Recuperado em 16 de junho de 2014, de http://www.planalto.gov.br/ccivil_03/_Ato2011-2014/2012/Lei/L12778.htm.

Bresser-Pereira, L. C. (1996). Da Administração pública burocrática à gerencial. Revista do Serviço Público, Brasília, 47(1), 7-40.

Brum, A. M. (2003). Respirando endomarketing. Porto Alegre: L\&PM.

Cançado, V. L., Moraes, L. F. R. de \& Silva, E. M. da. (2006). Comprometimento organizacional e práticas de gestão de recursos humanos: o caso da empresa XSA. Revista de Administração Mackenzie, São Paulo, 7(3), 11-37.

Carbone, P. P., Brandão, H. P., Leite, J. B. D. \& Vilhena, R. M. P. (2011). Gestão por competências e gestão do conhecimento. $3^{\mathrm{a}}$ Ed. Rio de Janeiro: FGV.

Carson, K. D. \& Bedeian, A. (1994). Career commitment: construction of a measure and examination of its psychometric properties. Journal of Vocational Behavior, 44(3), $237-$ 262.

Carvalho, I. M. V., Lustri, D., Rocha, J. L. C. da \& Souza, M. Z. de A. (2011). Cargos, Carreira e Remuneração. Rio de Janeiro: FGV. 
Castillo Blanco, F. A. (2003). Reflexiones em torno a la construcción de um nuevo sistema de empleo público. In: F. Castillo Blanco \& A. Olmedo (org.) Lecciones de Función Pública. Granada: CEMCI.

Chew, J. C. L. (2004). The influence of human resource management practices on the retention of core employees of Australian Organizations: an empirical study. Thesis (Doctor of Philosophy), Murdoch University.

Coelho, E. T. B. \& Roglio, K. D. D. (2010). Remuneração estratégica: um estudo qualitativo em instituições de ensino e empresas de outros setores. Anais do Encontro da Associação Nacional de Pós-Graduação e Pesquisa em Administração - EnANPAD. Rio de Janeiro, RJ, Brasil, 34.

Coelho Júnior, F. A. \& Borges-Andrade, J. E. (2008). Uso do conceito de aprendizagem em estudos organizacionais. Paidéia, 40(18), 221-234.

Coelho Júnior, F. A. (2011). Gestão do Desempenho Humano no Trabalho: interfaces teóricas, etapas constitutivas e implicações práticas. Anais do Encontro de Gestão de Pessoas e Relações de Trabalho - EnGPR. João Pessoa, PB, Brasil, 3.

Cohen, J. (1992). A power primer. Psychological Bulletin, 112(1), 155-159.

Cohen, A. (2007). Commitment before and after: an evaluation and reconceptualization of organizational commitment. Human Resource Management Review, 17(3), 336-354, setembro.

Demo, G. (2008). Desenvolvimento e validação da Escala de Percepção de Políticas de Gestão de Pessoas (EPPGP). Revista de Administração Mackenzie, São Paulo, 9(6), 77101 , setembro/outubro.

Demo, G. (2010). Políticas de gestão de pessoas, valores pessoais e justiça organizacional. Revista de Administração Mackenzie, São Paulo, 11(5), 55-81, setembro/outubro.

Demo, G., Fogaça, N., Nunes, I., Edrei, L. \& Francischeto, L. (2011). Políticas de gestão de pessoas no novo milênio: cenário dos estudos publicados nos periódicos da área de administração entre 2000 e 2010. Revista de Administração Mackenzie, São Paulo, 12(5), 15-42, setembro/outubro.

Demo, G., Neiva, E., Nunes, I \& Rozzetti, K. (2014). Políticas e práticas de recursos humanos. In: M. M. M. Siqueira (Org.), Novas medidas do comportamento organizacional: ferramentas de diagnóstico e de gestão. Porto Alegre: Artmed, 240-255.

Demo, G., Nunes, I., Fogaça, N., Barcelos, B. \& Roure, P. (2012). Gestão de Pessoas. In: G. Demo (Org.). Políticas de gestão de pessoas em organizações: estado da arte, produção nacional, agenda de pesquisa, medidas e estudos relacionais. São Paulo: Atlas, 3-48.

Demo, G., Martins, P. de R. \& Roure, P. (2013). Políticas de gestão de pessoas, comprometimento organizacional e satisfação no trabalho na Livraria Cultura. Revista Alcance - Eletrônica, 20(2), 237-254, abril/junho.

Dessler, G. (1996). Conquistando o comprometimento: como construir e manter uma força de trabalho competitiva. São Paulo: Makron Books.

Diniz, M. da G. (2001). Fatores ergonômicos das condições de trabalho e a qualidade de vida no trabalho no setor de transportes urbanos rodoviários: estudo dos casos de Campina Grande e Lisboa. Anais do Encontro Nacional da Associação Nacional de Pós-Graduação e Pesquisa em Administração - EnANPAD. Campinas, SP, Brasil, 25. 
Dutra, J. S. (2004). Competências: conceitos e instrumentos para a gestão de pessoas na empresa moderna. São Paulo: Atlas.

Facchini, A. R. (2007). Práticas de recursos humanos e comprometimento organizacional. Tese (Doutorado em Engenharia de Produção), Universidade Federal do Rio Grande do Sul, Porto Alegre, Brasil.

Fernandes, C. C. C. (2013). Profissionalização da alta gerência: trajetória, experiências de referência e perspectivas no Brasil. Revista de Políticas Públicas e Gestão Governamental - Res Publica, 12(1), 57-71, janeiro/junho.

Flauzino, D. P. \& Borges-Andrade, J. E. (2008). Comprometimento de servidores públicos e alcance de missões organizacionais. Revista de Administração Pública, 42(2), 253-73, março/abril.

Foguet, J. M. B. \& Gallart, G. C. (2001). Modelos de ecuaciones estructurales. Madrid: La Muralla.

Fonseca, D. R. da, Meneses, P. P. M., Isidro-Filho, A. \& Campos, N. G. (2013). Autonomia para gestão estratégica de pessoas no setor público federal: perspectivas de análise e agenda de pesquisa. Revista de Administração Pública, Rio de Janeiro, 47(6), 1451-1475, novembro/dezembro.

Freire, P. (2008). Pedagogia da autonomia. São Paulo: Cortez.

Freitas, M. E. (2000). A questão do imaginário e a fronteira entre a cultura organizacional e a psicanálise. In: F. C. P. Motta \& M. E. Freitas (Org.) Vida psíquica e organização. $2^{\mathrm{a}}$ Ed. Rio de Janeiro: FGV.

Gaulejac, V. (2007). Gestão como doença social: ideologia, poder gerencialista e fragmentação social. São Paulo: Editora Ideias \& Letras.

Goulet, L. \& Singh, P. (2002). Carrer commitment: a reexamination and an extension. Journal of Vocational Behavior, 61(1), 73-91.

Grohmann, M. Z., Cunha, L. V. da \& Silinske, J. (2013). Relações entre motivação, satisfação, comprometimento e desempenho no trabalho: estudo em um Hospital Público. Anais do Encontro de Gestão de Pessoas e Relações de Trabalho - EnGPR. Brasília, DF, Brasil, 4.

Hair, J. F., Jr., Anderson, R. E., Tatham, R. L. \& Black, W. C. (2009). Análise multivariada de dados. Porto Alegre: Bookman.

Hanashiro, D. M. M. (2008). Recompensando pessoas. In: D. M. M. Hanashiro, M. L. M. Teixeira \& L. M. Zaccarelli (Org.). Gestão do fator humano: uma visão baseada em stakeholders. São Paulo: Saraiva.

Höpner, A., Garay, A. B. S., Santos, C. G. dos, Silva, F. M. da, Medeiros, I. B. de O. \& Flach, L. (2008). Recursos Humanos Estratégico: atuação e papéis sob a ótica de profissionais de RH e gestores de outras áreas. Anais do Encontro da Associação Nacional de PósGraduação e Pesquisa em Administração - EnANPAD. Rio de Janeiro, RJ, Brasil, 32.

Horta, P., Demo, G. \& Roure, P. (2012). Políticas de gestão de pessoas, confiança e bemestar: estudo em uma multinacional. Revista de Administração Contemporânea, Rio de Janeiro, 16(4), 566-585, julho/agosto.

Hu, L. \& Bentler, P. M. (1995). Evaluating model fit. In: R. H. HOYLE. Structural equation modeling. London: Sage Publications. 
Kahn, J. H. (2006). Factor analysis in counseling psychology research, training, and practice: principles, advances and applications. The Counseling Psychologist, 34(5), 684-718.

Katou, A. A. (2012). Investigating reverse causality between human resource management policies and organizational performance in small firms. Management Research Review, 35(2), 134-156.

Kramer, G. G. \& Faria, J. H. (2007). Vínculos organizacionais. Revista de Administração Pública, Rio de Janeiro, 41(1), 83-104, janeiro/fevereiro.

Lacaz, F. A. C. (2007). O campo Saúde do Trabalhador: resgatando conhecimentos e práticas sobre as relações trabalho-saúde. Cad. Saúde Pública, 23(4), 757-766.

Lacombe, B. M. B. \& Chu, R. A. (2008). Políticas e práticas de gestão de pessoas: as abordagens estratégica e institucional. Revista de Administração de Empresas, São Paulo, 48(1), 25-35, janeiro/março.

Lee, K., Carswell, J. \& Allen, N. (2000). A meta-analytic review of occupational commitment: relations with person and work-related variables. Journal of Applied Psychology, 85(5), 799-811.

Legge, K. (1995). Human resource management: rhetorics and realities. London: Macmillan.

Leite, M. M. J., Gualda, D. M. R., Gonçalves, V. L. M., Castilho, V., Ortiz, D. C. F., Fugulin, F. M. T., Carmo, D. R. B. \& Coan, T. C. M. (1999). Análise do instrumento utilizado no processo de avaliação de desempenho da equipe de enfermagem do hospital universitário da USP. Revista da Escola Enfermagem - USP, 33(3), 265-278, setembro.

Leite, N. R. P. \& Albuquerque, L G. (2011). Gestão estratégica de pessoas, comprometimento e contrato psicológico: o caso Vale. Revista de Administração da USP, 46(1), 19-31, janeiro/março.

Leite, N. R. P. \& Albuquerque, L G. (2013). Gestão estratégica de pessoas, estratégia de retenção de profissionais e comprometimento organizacional em uma estrutura organizacional remota. Revista de Administração da Universidade Federal de Santa Maria, 6(4), 803-822, dezembro.

Limongi-França, A. C. \& Rodrigues, A. L. (2007). Stress e Trabalho: uma abordagem psicossomática. $4^{\mathrm{a}}$ Ed., São Paulo: Atlas.

Loiola, E., Bastos, A. V. B. \& Teixeira, J. C. de A. (2003). A adoção de práticas inovadoras de organização e produção no Brasil. Anais do Simpósio de Engenharia de Produção SIMPEP, Bauru, SP, Brasil, 10.

Lucena, M. D. da S. (1992). Avaliação de Desempenho. São Paulo: Atlas.

Luck, H. (2006). Concepções e processos democráticos de gestão educacional. Petrópolis: Editora Vozes.

Mabey, C., Salaman, G., \& Storey, J. (1998). Strategic human resource management: the theory of practice and the practice of theory. In: C. Mabey, G. Salaman \& J. Storey, (Orgs.). Strategic human resource management. London: Sage.

Madureira, C. (2013). Profissionalização e avaliação dos dirigentes de topo na Administração Pública: o caso de Portugal. In: C. Madureira \& Asensio (Orgs.). Handbook de Administração Pública. Lisboa: INA Editora.

Maggi, B. (2006). Do agir organizacional: um ponto de vista sobre o trabalho, o bem estar, a aprendizagem. São Paulo: Edgar Blucher. 
Maranhão, M. L. \& Sá, M. A. D. de. (2013). Cultura organizacional e práticas de qualidade de vida no trabalho: um estudo de múltiplos casos em palcos organizacionais de restaurantes do Recife - PE. Anais do Encontro da Associação Nacional de Pós-Graduação e Pesquisa em Administração - EnANPAD. Rio de Janeiro, RJ, Brasil, 37.

Marras, J. P. (2012). Administração da remuneração. $2^{\mathrm{a}}$ Ed. São Paulo: Pearson Education.

Mascarenhas, A. O. (2008). Gestão estratégica de pessoas: evolução, teoria e crítica. São Paulo: Cengage Learning.

Medeiros, C. A. F., Albuquerque, L. G. de, Siqueira, M. \& Marques, G. M. (2003). Comprometimento Organizacional: o Estado da Arte da Pesquisa no Brasil. Revista de Administração Contemporânea, Rio de Janeiro, 7(4), 187-29, outubro/dezembro.

Meneses, P. P. M. (2007). Treinamento e desempenho organizacional: contribuição dos modelos lógicos e do método quase-experimental para avaliações de ações educacionais. Análise, Porto Alegre, 18(1), 180-199, janeiro/junho.

Meneses, P. P. M., Zerbini, T. \& Abbad, G. (2010). Manual de treinamento organizacional. $3^{\text {a }}$ Ed. Porto Alegre: Artmed Editora.

Menezes, I. G. (2006). Escalas de Intenções Comportamentais de Comprometimento Organizacional (EICCO): concepção, desenvolvimento, validação e padronização. Dissertação (Mestrado em Psicologia), Universidade Federal da Bahia, Salvador, Brasil.

Menezes, I. G. (2009). Comprometimento organizacional: construindo um conceito que integre atitudes e intenções comportamentais. Tese (Doutorado em Psicologia), Universidade Federal da Bahia, Salvador, Brasil.

Menezes, I. G. \& Bastos, A. V. B. (2010). Construção, desenvolvimento e validação da Escala de Intenções Comportamentais de Comprometimento Organizacional (EICCO). Avaliação Psicológica, 9(1), 119-127, abril.

Meyer, J. P. \& Allen, N. J. (1991). A three-component conceptualization of organization commitment. Human Resource Management Review, 1(1), 61-89.

Meyer, J. P. \& Smith. C. (2000). HRM practices and organizational commitment: test of a mediation model. Canadian Journal Of Administrative Sciences Halifax, 17, 319-331.

Meyer, J. P., Stanley, D. J., Herscovich, L. \& Topolnytsky, L. (2002). Affective, continuance, and normative commitment to the organization: a meta-analysis of antecedents, correlates, and consequences. Journal of Vocational Behavior, 61, 20-52.

Milkovich, G. \& Boudreau, J. (2000). Administração de Recursos Humanos. São Paulo: Atlas.

Moita Neto, J. M. (2004). Estatística Multivariada: uma visão didática e metodológica. Revista de Filosofia e Ensino. Disponível em: http://criticanarede.com/cien_estatistica.html. Acesso em: 29 de outubro de 2014.

Mowday, R. T., Porter, L. W. \& Steers, R. M. (1982). Employee-organization linkages: the psychology of commitment, absenteism and turnover. New York: Academic Press.

Nascimento, A. de L. do. (2013). Comprometimento no trabalho: percepção sobre o construto e sua influência na prática cotidiana de gestores públicos. Anais do Encontro da Associação Nacional de Pós-Graduação e Pesquisa em Administração - EnANPAD. Rio de Janeiro, RJ, Brasil, 37. 
Osborne, J. W. (2002). Notes on the use of data transformations. Practical Assessment, Research \& Evaluation, 8(6).

Osborne, J. W. (2010). Improving your data transformations: Applying the Box-Cox transformation. Practical Assessment, Research \& Evaluation, 15(12).

Pacheco, R. S. (2010). Agenda da nova gestão pública. In: M. R. Loureiro, F. L. Abrúcio \& R. S. Pacheco (Orgs.). Burocracia e política no Brasil: desafios para a ordem democrática no séc. XXI. Rio de Janeiro: FGV.

Pádua, I. de O. P. \& Honório, L. C. (2013). Vínculos Organizacionais: Comparando Professores de Instituições Mineiras de Ensino Superior. Anais do Encontro da Associação Nacional de Pós-Graduação e Pesquisa em Administração - EnANPAD. Rio de Janeiro, RJ, Brasil, 37.

Pilati, R. (2006). História e Importância de TD\&E. In: J. E. Borges-Andrade, G. S. Abbad \& L. Mourão (Orgs.). Treinamento, desenvolvimento e educação em organizações e trabalho: fundamentos para a gestão de pessoas. Porto Alegre: Artmed Editora, 159-176.

Pilati, R. \& Laros, J. A. (2007). Modelos de equações estruturais em Psicologia: conceitos e aplicações. Psicologia: Teoria e Pesquisa, 23(2), 205-216.

Pires, A. K. (2005). Gestão por competências em organizações de governo. Brasília: ENAP.

Pontes, B. R. (2005). Avaliação de desempenho: nova abordagem. $9^{\text {a }}$ Ed. São Paulo: LTR.

Robbins, S. P., Judge, T. A. \& Sobral, F. (2010). Comportamento organizacional: teoria e prática no contexto brasileiro. $14^{\mathrm{a}}$ Ed. São Paulo: Pearson Prentice Hall.

Rodrigues, A. C. A. \& Bastos, A. V. B. (2010). Problemas conceituais e empíricos na pesquisa sobre comprometimento organizacional: uma análise crítica do modelo tridimensional de J. Meyer e N. Allen. Revista Psicologia, Organizações e Trabalho, 10(2), 129-144.

Rodrigues, A. C. A. \& Bastos, A. V. B. (2011). Do comprometimento de continuação ao entrincheiramento organizacional: evidências da sobreposição entre os construtos. Anais do Encontro da Associação Nacional de Pós-Graduação e Pesquisa em Administração EnANPAD, Rio de Janeiro, RJ, Brasil, 35.

Rodrigues, A. C. A., Gondim, S. M. G., Bastos, A. V. B. \& Sakamoto, R. (2013). Como se constroem e se desenvolvem o entrincheiramento e o comprometimento com a organização: análise qualitativa de diferentes trajetórias profissionais. Anais do Encontro da Associação Nacional de Pós-Graduação e Pesquisa em Administração - EnANPAD. Rio de Janeiro, RJ, Brasil, 37.

Rosseel, Y. (2012). Lavaan: an $\mathrm{R}$ package for structural equation modeling. Journal of Statistical Software, 48(2).

Rowe, D. E. O., Bastos, A. V. B. \& Pinho, A. N. M. (2011). Comprometimento e Entrincheiramento na Carreira: um Estudo de suas Influências no Esforço Instrucional do Docente do Ensino Superior. Revista de Administração Contemporânea, Rio de Janeiro, 15(6), novembro/dezembro.

Salles, D. M. R. \& Nogueira, M.G. (2006). Carreiras no serviço público federal: antigos dogmas, novas perspectivas. In: M. Balassiano \& I. S. A. da Costa (Orgs.), Gestão de carreiras: dilemas e perspectivas. Rio de Janeiro: Atlas, 134-149. 
Saravia, E. (2006). O sistema de carreira no setor público: descrição análise comparativa e perspectiva. In M. Balassiano \& I. S. A. da Costa (Orgs.), Gestão de carreiras: dilemas e perspectivas. Rio de Janeiro: Editora Atlas, 150-178.

Schalk, R. \& Curseu, P. L. (2010). Cooperation in organizations. Journal of Managerial Psychology, 25(5), 453-459.

Secchi, L. (2009). Modelos organizacionais e reformas da administração pública. Revista de Administração Pública, 43(2), 347-369.

Senge, P. (1998). Leading organizations: perspectives for a new era. London: Sage Publications.

Silva, H. S. da. (2012). Recrutamento e seleção de docentes no Instituto Federal de Educação Ciência e Tecnologia do Rio de Janeiro: uma proposta de gestão por competências. Anais do Encontro da Associação Nacional de Pós-Graduação e Pesquisa em Administração EnANPAD. Rio de Janeiro, RJ, Brasil, 36.

Silva, I. A. \& Silva M. C. A. (2008). E-learning corporativo: modalidade multimétodo de avaliação de cursos de capacitação a distância. Produtos \& Produção, 9(2), 21-32.

Silva, J. R. da, Balassiano, M. \& Silva, A. R. L. da. (2014). Burocrata proteano: articulações de carreira em torno e além do setor público. Revista de Administração Contemporânea, Rio de Janeiro, 18(1), 1-19, janeiro/fevereiro.

Silva, L. B. da. (2013). A gestão de pessoas e o sistema de reconhecimento e recompensa em organizações não governamentais. Anais do Encontro da Associação Nacional de PósGraduação e Pesquisa em Administração - EnANPAD. Rio de Janeiro, RJ, Brasil, 37.

Silva, L. M. C. e, Gondim, S. M. G., Macêdo, M. E. C. de \& Luna, A. F. (2012). Avaliação de necessidades e impacto do treinamento no trabalho: um estudo de caso no setor público. Anais do Encontro da Associação Nacional de Pós-Graduação e Pesquisa em Administração - EnANPAD. Rio de Janeiro, RJ, Brasil, 36.

Soldi, R. M. \& Zanelli, J. C. (2006). Comprometimento organizacional de trabalhadores tercerizados e efetivos: um estudo comparativo em uma empresa de telefonia. Anais do Encontro da Associação Nacional de Pós-Graduação e Pesquisa em Administração EnANPAD. Salvador, BA, Brasil, 30.

Solinger, O. N., Olffen, W. \& Roe, R. A. (2008). Beyond the three-component model of organizational commitment. Journal of Applied Psychology, 93(1), 70-83.

Somech, A. \& Bogler, R. (2002). Antecedents and consequences of teacher organizational and professional commitment. Educational Administration Quarterly, 38(4), 555-577.

Souza, D. A., Paixão C. R. \& Souza, E. A. B. (2011). Benefícios e dificuldades encontradas no processo de seleção de pessoas: uma análise do modelo de seleção por competências, sob a ótica de profissionais da área de gestão de pessoas. Gestão \& Regionalidade, 27, 4558.

Tabachnick, B. G. \& Fidell, L. S. (2001). Using multivariate statistics. New York: HarperCollins College Publishers.

Tavares, J. C., Souza, L. B. de \& Fogaça, N. (2014). Levantamento Bibliométrico sobre Avaliação de Treinamento no Trabalho: cenário dos estudos publicados em periódicos da área de Administração entre 2009 e 2013. Anais do Encontro da Associação Nacional de Pós-Graduação e Pesquisa em Administração - EnANPAD. Rio de Janeiro, RJ, Brasil, 38. 
Theotônio, K. S., Reis Neto, M. T. \& Lopes, S. A. (2013). A remuneração no Brasil: uma análise segundo os aspectos legais. Anais do Encontro da Associação Nacional de PósGraduação e Pesquisa em Administração - EnANPAD. Rio de Janeiro, RJ, Brasil, 37.

Torres, P. L. \& Fialho, F. A. P. (2009). Educação a distância: presente, passado e futuro. In: F. M. Litto \& M. M. Formiga (orgs.). Educação a distância: o estado da arte. São Paulo: Pearson Education do Brasil, 456- 461.

Ullman, J. B. (2007). Structural equation modeling. In: B. G. Tabachnick \& L. S. Fidell. Using Multivariate Statistics. $5^{\text {a }}$ Ed. EUA: Pearson Education.

Ulrich, D. (1998). Os Campeões de Recursos Humanos: inovando para obter os melhores resultados. São Paulo: Futura.

Veloso, L. (2007). Empresas, identidades e processos de identificação. Porto: Universidade do Porto.

Ventura, V. L. da S. (2012). A percepção da influência da gestão estratégica de pessoas no comprometimento organizacional pelos docentes do ensino superior. $128 \mathrm{f}$. Tese (doutorado em Administração), Universidade Nove de Julho - UNINOVE, São Paulo, Brasil.

Vergara, S. C. (2009). Projetos e relatórios de pesquisa em administração. São Paulo: Atlas.

Vilas Boas, A. A. \& Morin, E. (2013). Indicadores de qualidade de vida no trabalho para professores de instituições públicas de ensino superior: uma comparação entre Brasil e Canadá. Anais do Encontro da Associação Nacional de Pós-Graduação e Pesquisa em Administração - EnANPAD. Rio de Janeiro, RJ, Brasil, 37.

Weston, R. \& Gore Jr., P. A. (2006). A brief guide to structural equation modeling. The Counseling Psychologist, 34(5), 719-751.

Wood JR, T. \& Picarelli Filho, V. (2004). Remuneração e carreira por habilidades e por competências: preparando a organização para a era das empresas de conhecimento intensivo. $3^{\text {a }}$ Ed. São Paulo: Atlas.

Zagonel, A. G., Ferraz, D. L. da S. \& Soboll, L. A. P. (2012). Seleção, treinamento e avaliação: as práticas de gestão de pessoas e o processo de submissão de gestores. Anais do Encontro da Associação Nacional de Pós-Graduação e Pesquisa em Administração EnANPAD. Rio de Janeiro, RJ, Brasil, 36.

Zerbini, T. \& Abbad, G. (2010). Transferência de treinamento e impacto do treinamento no trabalho: análise crítica da literatura. Revista Psicologia: Organizações e Trabalho, 10, $97-$ 111.

Zimerman, D. E. (2000). Fundamentos básicos das grupoterapias. Porto Alegre: Artmed. 


\section{ANEXO A - Escala de Políticas e Práticas de Recursos Humanos (EPPRH) - versão original}

Você deve avaliar cada uma das 32 afirmativas seguintes na coluna à direita, de acordo com a escala abaixo, indicando o quanto você concorda ou discorda de cada uma delas, escolhendo o número (de 1 a 5) que melhor reflete a sua percepção em relação às políticas de recursos humanos da organização em que você trabalha. Por favor, não deixe nenhum item em branco! Organização em que trabalha:

\begin{tabular}{|c|c|c|c|c|}
\hline $\mathbf{1}$ & $\mathbf{2}$ & $\mathbf{3}$ & $\mathbf{4}$ & $\mathbf{5}$ \\
\hline $\begin{array}{c}\text { Discordo } \\
\text { totalmente da } \\
\text { afirmativa }\end{array}$ & $\begin{array}{c}\text { Discordo } \\
\text { parcialmente da } \\
\text { afirmativa }\end{array}$ & $\begin{array}{c}\text { Não concordo nem } \\
\text { discordo da } \\
\text { afirmativa/Não se } \\
\text { aplica }\end{array}$ & $\begin{array}{c}\text { Concordo } \\
\text { parcialmente com a } \\
\text { afirmativa }\end{array}$ & $\begin{array}{c}\text { Concordo } \\
\text { totalmente com a } \\
\text { afirmativa }\end{array}$ \\
\hline
\end{tabular}

1. Os processos de recrutamento (externo e interno) de candidatos a ocuparem vagas na organização onde eu trabalho são amplamente divulgados.

2. Os processos seletivos da organização onde eu trabalho são disputados, atraindo pessoas competentes.

3. Os testes de seleção da organização onde eu trabalho são conduzidos por pessoas capacitadas e imparciais.

4. A organização onde eu trabalho utiliza-se de vários instrumentos de seleção (ex: entrevistas, provas, etc.).

5. A organização onde eu trabalho divulga aos candidatos informações a respeito das etapas e critérios do processo seletivo.

6. A organização onde eu trabalho comunica aos candidatos seu desempenho ao final do processo seletivo.

7. A organização onde eu trabalho se preocupa com meu bem-estar.

8. A organização onde eu trabalho me trata com respeito e atenção.

9. A organização onde eu trabalho procura conhecer minhas necessidades e expectativas profissionais.

10. A organização onde eu trabalho estimula a minha participação nas tomadas de decisão e resolução de problemas.

11. A organização onde eu trabalho reconhece o trabalho que faço e os resultados que apresento (ex: elogios, matérias em jornais internos, etc.).

12. Na organização onde eu trabalho, os colaboradores e suas chefias desfrutam da troca constante de informações para o bom desempenho das funções.

13. Na organização onde eu trabalho, há um clima de compreensão e confiança dos chefes em relação aos seus colaboradores.

14. Na organização onde eu trabalho, há um clima de confiança e cooperação entre os colegas de trabalho.

15. Na organização onde eu trabalho, há coerência entre discurso e prática gerenciais.

16. A organização onde eu trabalho me ajuda a desenvolver as competências necessárias à boa realização das minhas funções (ex: treinamentos, participação em congressos, etc.).

17. Eu consigo aplicar no meu trabalho os conhecimentos e comportamentos aprendidos nos treinamentos/eventos de que participo.

18. A organização onde eu trabalho estimula a aprendizagem e a produção de conhecimento.

19. A organização onde eu trabalho preocupa-se com a minha saúde e qualidade de vida.

20. A organização onde eu trabalho me oferece benefícios básicos (ex: plano de saúde, auxílio transporte, auxílio alimentação, etc.).

21. Na organização onde eu trabalho, existem ações e programas de prevenção de acidentes e enfrentamento de incidentes.

22. A organização onde eu trabalho preocupa-se com a segurança de seus colaboradores, controlando o acesso de pessoas estranhas na empresa.

23. As instalações e as condições físicas (iluminação, ventilação, ruído e temperatura) do local onde eu trabalho são ergonômicas (adequadas e confortáveis).

24. A organização onde eu trabalho realiza avaliações de desempenho e competências periodicamente.

25. Na organização onde eu trabalho, a avaliação de desempenho e competências subsidia as decisões 
sobre promoções e aumento de salário.

26. Na organização onde eu trabalho, a avaliação de desempenho e competências subsidia a elaboração de um plano de desenvolvimento dos colaboradores.

27. Na organização onde eu trabalho, os critérios e os resultados da avaliação de desempenho e competências são discutidos com os colaboradores.

28. Na organização onde eu trabalho, os critérios e os resultados da avaliação de desempenho e competências são divulgados para os colaboradores.

29. A organização onde eu trabalho me oferece remuneração compatível com as minhas competências e formação/escolaridade.

30. Na organização onde eu trabalho, recebo incentivos (ex: promoções/funções comissionadas, bônus/prêmios/gratificações, etc.).

31. Na definição de seu sistema de recompensas, a organização onde eu trabalho considera as expectativas e sugestões de seus colaboradores.

32. Na organização onde eu trabalho, minha remuneração é influenciada pelos meus resultados.

Fonte: Demo et al. (2014). 


\section{ANEXO B - Escala de Intenções Comportamentais de Comprometimento Organizacional (EICCO) - versão original}

Em cada questão do questionário você irá encontrar situações que descrevem possíveis realidades do dia-a-dia do trabalho em uma organização. Frente a estas situações você deverá posicionar-se, considerando as duas opções extremas (A e B) descritas nos quadros abaixo. Marque com um X o intervalo entre as duas opções que indica o nível de proximidade de sua decisão em relação às duas opções oferecidas. $\mathrm{O}$ intervalo do meio deve ser assinalado quando você estiver em dúvida ou não souber que opção escolher.

1. Imagine que a organização em que você trabalha convoque uma reunião de voluntários uma vez por semana, no horário após o expediente, sem pagamento de horas-extras, a fim de discutir questões de interesse da própria organização. O que você faria?

\begin{tabular}{|c|}
\hline Opção A \\
\hline Eu compareceria a estas \\
reuniões, caso eu tivesse tal \\
horário disponível.
\end{tabular}

\begin{tabular}{c} 
\\
\cline { 2 - 2 } $\begin{array}{c}\text { Mesmo que pudesse, eu } \\
\text { não participaria destas } \\
\text { reuniões. }\end{array}$ \\
\hline
\end{tabular}

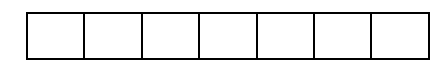

2. Imagine que você foi chamado para substituir um colega de outro setor durante um mês e que terá de aprender como executar as tarefas relacionadas ao cargo. Qual posição você assumiria?

\begin{tabular}{|c|}
\hline Opção A \\
\hline $\begin{array}{c}\text { Eu recusaria a proposta e } \\
\text { não buscaria aprender as } \\
\text { novas tarefas. }\end{array}$ \\
\hline
\end{tabular}

\begin{tabular}{|c|}
\hline Opção B \\
\hline $\begin{array}{c}\text { Eu aceitaria a proposta e } \\
\text { buscaria aprender as } \\
\text { novas tarefas. }\end{array}$ \\
\hline
\end{tabular}

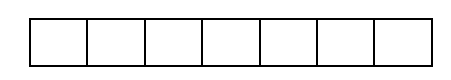

3. Em um determinado momento, sua organização necessita que você assuma encargos ou tarefas que se distanciam de seus interesses profissionais atuais. O que você faria?

\begin{tabular}{|c|}
\hline Opção A \\
\hline Aceitaria assumir tais \\
encargos e tarefas para \\
atender às necessidades da \\
organização. \\
\hline
\end{tabular}

\begin{tabular}{|c|}
\hline Opção B \\
\hline Não aceitaria tais \\
encargos e tarefas, apesar \\
da necessidade da \\
organização. \\
\hline
\end{tabular}

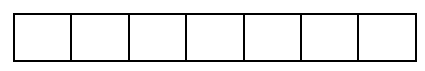

4. Em um contexto fora de sua organização, algumas pessoas que não trabalham nela tecem comentários, criticando-a injustamente. Qual a posição que você assumiria?

\begin{tabular}{|c|}
\hline Opção A \\
\hline $\begin{array}{c}\text { Eu defenderia a organização } \\
\text { das críticas. }\end{array}$ \\
\hline
\end{tabular}

\begin{tabular}{|c|}
\hline Opção B \\
\hline $\begin{array}{c}\text { Eu não me exporia frente } \\
\text { às pessoas defendendo a } \\
\text { organização. }\end{array}$ \\
\hline
\end{tabular}

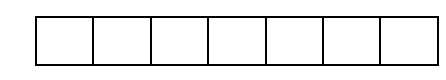


5. Imagine que, devido a algum motivo irrelevante, haja divergências e tensões entre diferentes setores dentro da organização em que você trabalha. O que você faria para melhorar tal situação?

\begin{tabular}{|c|}
\hline Opção A \\
\hline Eu não interviria e deixaria \\
que os setores resolvessem \\
as divergências e tensões \\
por si mesmos. \\
\hline
\end{tabular}

\begin{tabular}{|c|}
\hline Opção B \\
\hline Eu interviria no sentido \\
de ajudar a superar as \\
divergências e tensões \\
entre diferentes setores. \\
\hline
\end{tabular}

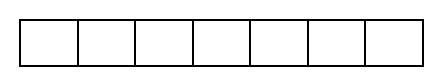

6. Na sua organização, você é avaliado como tendo uma produtividade satisfatória. No entanto, ela lhe solicita um aumento desta produtividade por tempo indeterminado, mantendo as mesmas condições de trabalho. $\mathrm{O}$ que você faria?

\begin{tabular}{|c|}
\hline Opção A \\
\hline $\begin{array}{c}\text { Eu procuraria melhorar } \\
\text { minha produtividade e meu } \\
\text { desempenho. }\end{array}$ \\
\hline
\end{tabular}

\begin{tabular}{|c|}
\hline Opção B \\
\hline Eu manteria o mesmo \\
nível de desempenho e \\
produtividade que tenho. \\
\hline
\end{tabular}

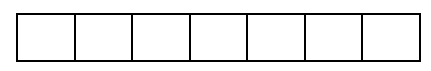

7. Em comparação com organizações similares, os processos de trabalho sob a responsabilidade do seu setor são mais lentos, e seguem somente os procedimentos de rotina. Você possui uma ideia inovadora e que poderia reduzir o tempo de trabalho e tornar o trabalho mais diversificado. O que você faria?

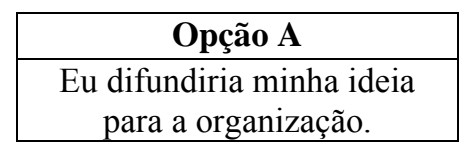

\begin{tabular}{|c|}
\hline Opção B \\
\hline $\begin{array}{l}\text { Eu não difundiria minha } \\
\text { ideia para a organização. }\end{array}$ \\
\hline
\end{tabular}

8. O sistema de avaliação de desempenho da sua organização detectou que a produtividade da sua equipe de trabalho não foi satisfatória, embora o seu desempenho tenha sido o esperado. Buscando a melhoria do desempenho geral da equipe, ela the solicita que aumente conjuntamente o seu nível de produtividade. Diante da solicitação, o que você faria?

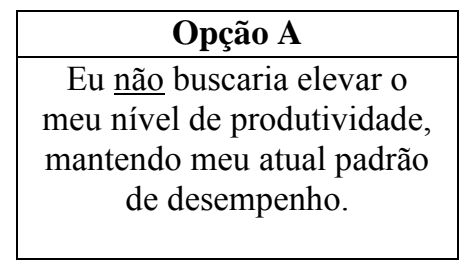

\begin{tabular}{|c|}
\hline Opção B \\
\hline Eu buscaria elevar o meu \\
nível de produtividade, \\
tendo em vista a \\
melhoria do desempenho \\
da equipe. \\
\hline
\end{tabular}

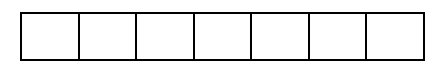

9. As atividades que foram delegadas a sua equipe foram concluídas com êxito. Entretanto, uma outra equipe de trabalho próxima a sua the solicita auxílio para a finalização das tarefas. Diante da possibilidade de contribuição, o que você faria?

\begin{tabular}{|c|}
\hline Opção A \\
\hline Eu não ajudaria a outra \\
equipe a finalizar suas \\
atividades.
\end{tabular}

\begin{tabular}{|c|}
\hline Opção B \\
\hline Eu ajudaria a outra \\
equipe a finalizar suas \\
atividades. \\
\hline
\end{tabular}

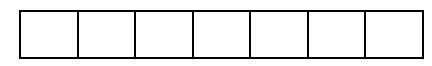


10. A organização na qual você trabalha teve de fazer uma redução no quadro de pessoal, requerendo de você a realização de mais tarefas do que as exigidas para o seu cargo, tendo em vista a manutenção do nível de produtividade organizacional. Diante da solicitação e sabendo que você possui o conhecimento necessário para realizar essas novas atividades, o que você faria?

\begin{tabular}{|c|}
\hline Opção A \\
\hline $\begin{array}{c}\text { Eu não } \\
\text { novsumiria essas tarefas. }\end{array}$ \\
\hline
\end{tabular}

\begin{tabular}{|c|}
\hline Opção B \\
\hline $\begin{array}{c}\text { Eu assumiria essas novas } \\
\text { tarefas. }\end{array}$ \\
\hline
\end{tabular}

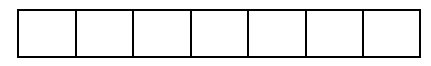

11. Suponha que sua organização lhe solicitou que se engaje em atividades para melhorar a forma como a organização é vista pela sociedade. Qual decisão você tomaria?

\begin{tabular}{|c|}
\hline Opção A \\
\hline $\begin{array}{c}\text { Eu tomaria alguma iniciativa } \\
\text { no sentido de promover tal } \\
\text { melhoria. }\end{array}$ \\
\hline
\end{tabular}

\begin{tabular}{|c|}
\hline Opção B \\
\hline Eu não tomaria qualquer \\
iniciativa no sentido de \\
promover tal melhoria. \\
\hline
\end{tabular}

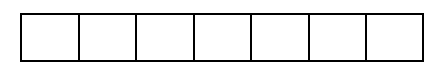

12. Em uma conversa descontraída com seus colegas de trabalho, um deles questiona e critica injustamente a empresa onde você trabalha. Que posição você assumiria?

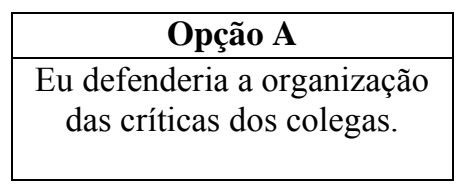

\begin{tabular}{|c|}
\hline Opção B \\
\hline Eu não defenderia a \\
organização das críticas \\
dos colegas.
\end{tabular}

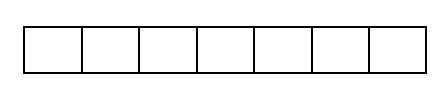

13. A organização na qual você trabalha adota um modelo de gestão participativa para que seus funcionários possam se envolver no processo de elaboração de novos projetos a partir do próximo ano. Diante da possibilidade de participação, o que você faria?

\begin{tabular}{|c|}
\hline Opção $\mathbf{A}$ \\
\hline $\begin{array}{c}\text { Eu não me ofereceria para } \\
\text { participar desses novos } \\
\text { projetos. }\end{array}$ \\
\hline
\end{tabular}

\begin{tabular}{|c|}
\hline Opção B \\
\hline $\begin{array}{c}\text { Eu me ofereceria para } \\
\text { participar desses novos } \\
\text { projetos. }\end{array}$ \\
\hline
\end{tabular}

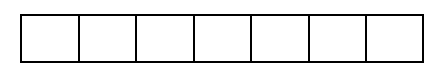

14. A organização redefiniu as metas de desempenho para o próximo ano e isso exigirá de você uma carga de trabalho adicional. Que posição você assumiria?

\begin{tabular}{|c|}
\hline Opção A \\
\hline $\begin{array}{c}\text { Eu mudaria minha forma de } \\
\text { trabalhar para me adequar às } \\
\text { novas metas. }\end{array}$ \\
\hline
\end{tabular}

\begin{tabular}{|c|}
\hline Opção B \\
\hline Eu não mudaria minha \\
forma de trabalhar, não \\
me adequando às novas \\
metas. \\
\hline
\end{tabular}

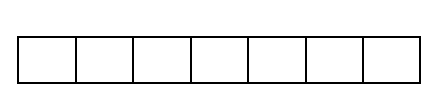


15. A organização está implantando programas de melhoria do seu desempenho e da qualidade de seus serviços. Este programa exige mudanças na sua forma de trabalhar e a necessidade de uma nova adaptação ao seu trabalho. O que você faria?

\begin{tabular}{|c|}
\hline Opção A \\
\hline Eu não me engajaria no \\
programa.
\end{tabular}

\begin{tabular}{|c|}
\hline Opção B \\
\hline $\begin{array}{c}\text { Eu me engajaria no } \\
\text { programa. }\end{array}$ \\
\hline
\end{tabular}

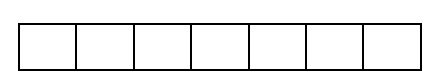

16. Imagine que sua organização implantou um sistema de críticas e sugestões acessível a todos os funcionários. Que posição você assumiria?

\begin{tabular}{|c|}
\hline Opção A \\
\hline Caso tivesse críticas e \\
sugestões, eu as apresentaria \\
à organização.
\end{tabular}
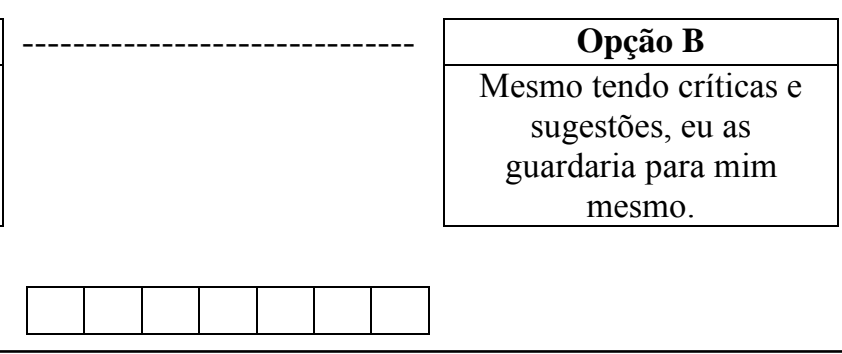

17. Um dos clientes da organização na qual você trabalha dirige críticas ao atendimento prestado pela empresa e insinua que a maior concorrente possui uma qualidade de atendimento superior. Qual posição você assumiria?

\begin{tabular}{|c|}
\hline Opção A \\
\hline $\begin{array}{c}\text { Eu não defenderia a } \\
\text { organização das críticas do } \\
\text { cliente. }\end{array}$ \\
\hline
\end{tabular}

\begin{tabular}{|c|}
\hline Opção B \\
\hline Eu defenderia a \\
organização das críticas \\
do cliente.
\end{tabular}

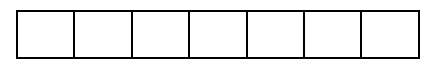

18. A organização onde você trabalha está sendo reestruturada, o que implica em redimensionamento de setores e remanejamento de pessoal. Estas mudanças são vistas pela organização como necessárias para a melhoria de seu desempenho. Que posição você assumiria diante destas mudanças?

\begin{tabular}{|c|}
\hline Opção A \\
\hline $\begin{array}{c}\text { Eu faria o possível para não } \\
\text { mudar de setor. }\end{array}$ \\
\hline
\end{tabular}

\begin{tabular}{|c|}
\hline Opção B \\
\hline Eu mudaria de setor, \\
caso fosse necessário. \\
\hline
\end{tabular}

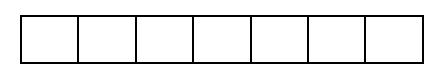

19. Dificuldades financeiras levam a sua organização a restringir benefícios e vantagens que vinha oferecendo ao trabalhador. Que posição você assumiria?

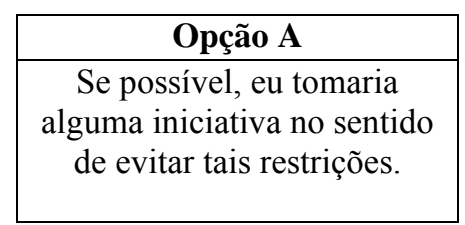

\begin{tabular}{|c|}
\hline Opção B \\
\hline Mesmo que possível, eu \\
não tomaria qualquer \\
tipo de iniciativa, \\
aceitando as restrições. \\
\hline
\end{tabular}

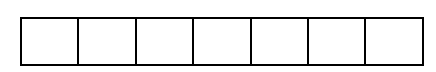


20. A organização está enfrentando um problema cujo encaminhamento está confiado a um outro setor de trabalho que não é o seu. Você possui alguma ideia de como resolvê-lo. O que você faria?

\begin{tabular}{|c|}
\hline Opção A \\
\hline $\begin{array}{c}\text { Eu me ofereceria para } \\
\text { ajudar. }\end{array}$ \\
\hline
\end{tabular}

\begin{tabular}{|c|}
\hline Opção B \\
\hline Eu não me ofereceria \\
para ajudar.
\end{tabular}

Fonte: Menezes (2006); Menezes e Bastos (2010). 


\section{APÊNCICE A - Instrumento de Pesquisa: Questionário}
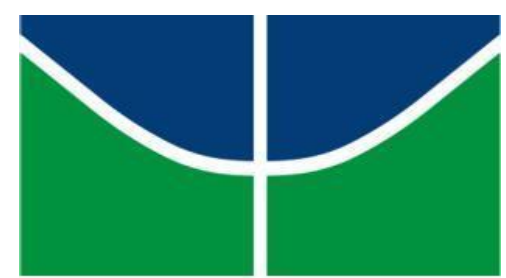

Universidade de Brasília - UnB

\section{Pesquisa sobre Comprometimento Organizacional e Políticas de Gestão de Pessoas}

\section{CONVITE E INFORMAÇÕES PARA PARTICIPAÇÃO EM PESQUISA ACADÊMICA}

Você está sendo convidado (a) a participar de uma pesquisa que se relaciona com vários aspectos da sua vida no trabalho, e tem como objetivo verificar a relação entre e o comprometimento organizacional e as políticas de gestão de pessoas do Ministério do Meio Ambiente - MMA. A presente pesquisa está sob a coordenação da mestranda Adriana Alves Xavier Durão (servidora do MMA), com orientação do Prof. ${ }^{\circ}$ Dr. Antônio Isidro da Silva Filho (PPGA/UnB), e conta com o apoio do MMA.

Trata-se de uma pesquisa de âmbito acadêmico e não da organização, assim, os resultados serão analisados fora da organização e esta não terá acesso às informações individuais que você nos fornecer.

Não existe resposta certa ou errada. A sua resposta deve refletir fielmente, com honestidade, o que você pensa sobre cada afirmativa. Pedimos que não seja deixado nenhum item sem resposta. Você precisará dispor apenas de 10 minutos do seu tempo para responder a pesquisa.

É importante ressaltar que as questões sócio demográficas ao final do questionário buscam apenas caracterizar a amostra da pesquisa. Ademais, os dados desta pesquisa são confidenciais e serão utilizados exclusivamente para fins acadêmicos.

A sua participação nesta pesquisa é voluntária, não incorrendo em qualquer prêmio ou prejuízo.

Para esclarecer dúvidas e fazer sugestões entre em contato por meio do e-mail pesquisacomprometimento@gmail.com.

Contamos com sua participação!

Adriana Alves Xavier Durão

Mestranda do curso de Mestrado Profissional em Administração (PPGA/UnB)

Prof. $^{\circ}$ Dr. Antônio Isidro da Silva Filho (PPGA/UnB)

\section{TERMO DE CONSENTIMENTO}

Confirmo que li e entendi as informações relativas a esta pesquisa e que voluntariamente concordo em participar. 


\section{PARTE I:}

Em cada questão apresentada a seguir você irá encontrar situações que descrevem possíveis realidades do dia-adia do trabalho no Ministério do Meio Ambiente. Frente a estas situações você deverá posicionar-se, considerando as duas opções extremas (A e B) descritas nos quadros abaixo. Marque o intervalo entre as duas opções que indica o nível de proximidade de sua decisão em relação às duas opções oferecidas. O intervalo do meio deve ser assinalado quando você estiver em dúvida ou não souber que opção escolher, conforme exemplificado abaixo:

Exemplo: imagine que você tenha sido convidado para participar de um evento dentro da organização e que deverá apresentar suas atividades de trabalho para os demais colegas do órgão. Diante de tal solicitação, o que você faria?

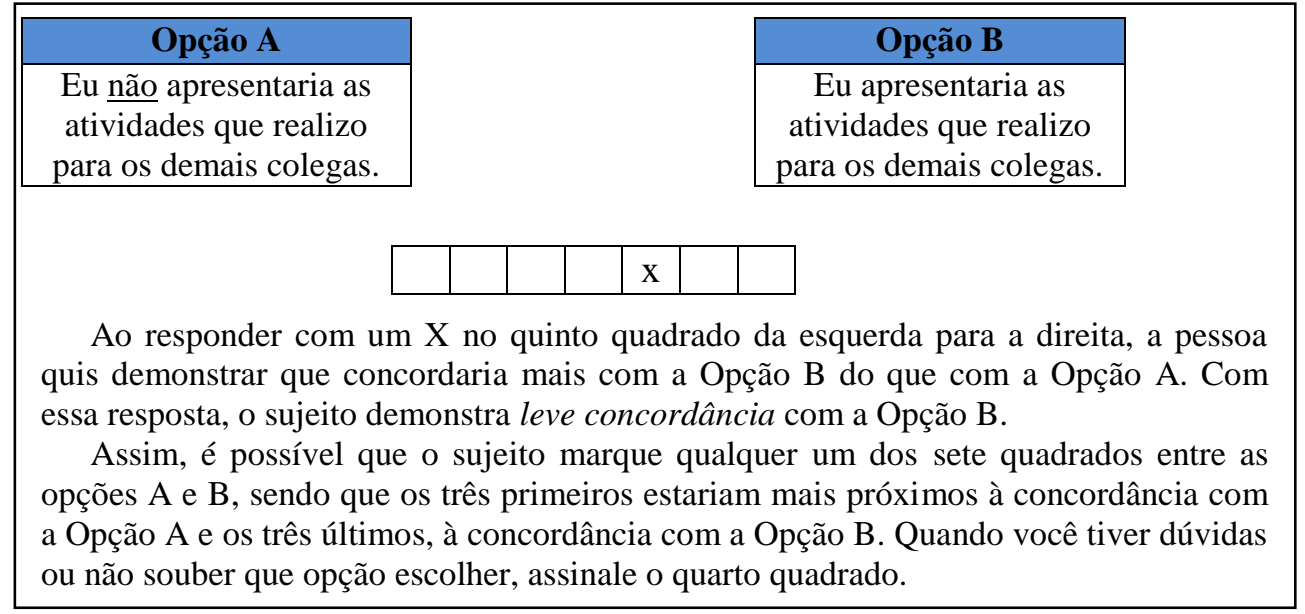

1. Imagine que a organização em que você trabalha convoque uma reunião de voluntários uma vez por semana, no horário após o expediente, sem pagamento de horas-extras, a fim de discutir questões de interesse da própria organização. O que você faria?

\begin{tabular}{|c|}
\hline Opção A \\
\hline $\begin{array}{c}\text { Eu compareceria a estas } \\
\text { reuniões, caso eu tivesse tal } \\
\text { horário disponível. }\end{array}$ \\
\hline
\end{tabular}

\begin{tabular}{|c|}
\hline Opção B \\
\hline $\begin{array}{c}\text { Mesmo que pudesse, eu } \\
\text { não participaria destas } \\
\text { reuniões. }\end{array}$ \\
\hline
\end{tabular}

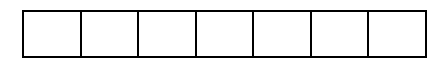

2. Imagine que você foi chamado para substituir um colega de outro setor durante um mês e que terá de aprender como executar as tarefas relacionadas ao cargo. Qual posição você assumiria?

\begin{tabular}{|c|}
\hline Opção A \\
\hline $\begin{array}{l}\text { Eu recusaria a proposta e } \\
\text { não buscaria aprender as } \\
\text { novas tarefas. }\end{array}$ \\
\hline
\end{tabular}

\begin{tabular}{|c|}
\hline Opção B \\
\hline $\begin{array}{c}\text { Eu aceitaria a proposta e } \\
\text { buscaria aprender as } \\
\text { novas tarefas. }\end{array}$ \\
\hline
\end{tabular}

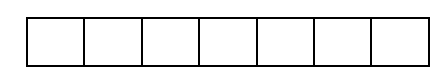

3. Em um determinado momento, sua organização necessita que você assuma encargos ou tarefas que se distanciam de seus interesses profissionais atuais. O que você faria?

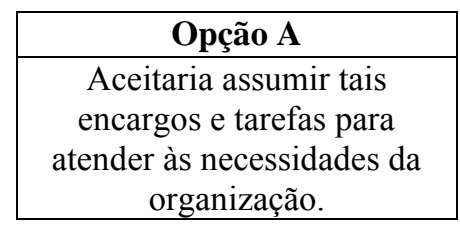

\begin{tabular}{|c|}
\hline Opção B \\
\hline Não aceitaria tais \\
encargos e tarefas, apesar \\
da necessidade da \\
organização. \\
\hline
\end{tabular}


4. Em um contexto fora de sua organização, algumas pessoas que não trabalham nela tecem comentários, criticando-a injustamente. Qual a posição que você assumiria?

\begin{tabular}{|c|}
\hline Opção A \\
\hline $\begin{array}{c}\text { Eu defenderia a organização } \\
\text { das críticas. }\end{array}$ \\
\hline
\end{tabular}

\begin{tabular}{|c|}
\hline Opção B \\
\hline $\begin{array}{c}\text { Eu não me exporia frente } \\
\text { às pessoas defendendo a } \\
\text { organização. }\end{array}$ \\
\hline
\end{tabular}

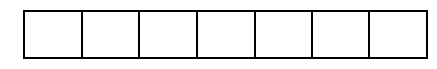

5. Imagine que, devido a algum motivo irrelevante, haja divergências e tensões entre diferentes setores dentro da organização em que você trabalha. O que você faria para melhorar tal situação?

\begin{tabular}{|c|}
\hline Opção A \\
\hline Eu não interviria e deixaria \\
que os setores resolvessem \\
as divergências e tensões \\
por si mesmos. \\
\hline
\end{tabular}

\begin{tabular}{|c|}
\hline Opção B \\
\hline Eu interviria no sentido \\
de ajudar a superar as \\
divergências e tensões \\
entre diferentes setores. \\
\hline
\end{tabular}

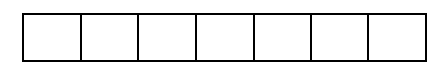

6. Na sua organização, você é avaliado como tendo uma produtividade satisfatória. No entanto, sua chefia lhe solicita um aumento desta produtividade por tempo indeterminado, mantendo as mesmas condições de trabalho. O que você faria?

\begin{tabular}{|c|}
\hline Opção A \\
\hline Eu procuraria melhorar \\
minha produtividade e meu \\
desempenho.
\end{tabular}

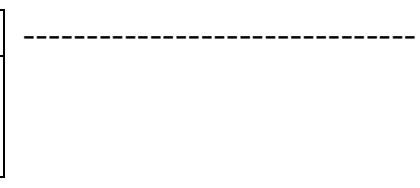

\begin{tabular}{|c|}
\hline Opção B \\
\hline Eu manteria o mesmo \\
nível de desempenho e \\
produtividade que tenho. \\
\hline
\end{tabular}

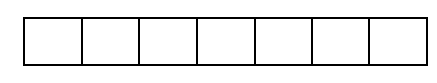

7. Em comparação com organizações similares, os processos de trabalho sob a responsabilidade do seu setor são mais lentos, e seguem somente os procedimentos de rotina. Você possui uma ideia inovadora e que poderia reduzir o tempo de trabalho e tornar o trabalho mais diversificado. O que você faria?

\begin{tabular}{|c|}
\hline Opção A \\
\hline $\begin{array}{c}\text { Eu difundiria minha ideia } \\
\text { para a organização. }\end{array}$ \\
\hline
\end{tabular}

\begin{tabular}{|c|}
\hline Opção B \\
\hline Eu não difundiria minha \\
ideia para a organização. \\
\hline
\end{tabular}

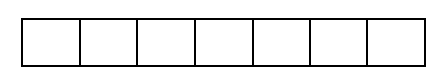

8. O sistema de avaliação de desempenho da sua organização detectou que a produtividade da sua equipe de trabalho não foi satisfatória, embora o seu desempenho tenha sido o esperado. Buscando a melhoria do desempenho geral da equipe, a sua chefia lhe solicita que aumente conjuntamente o seu nível de produtividade. Diante da solicitação, o que você faria?

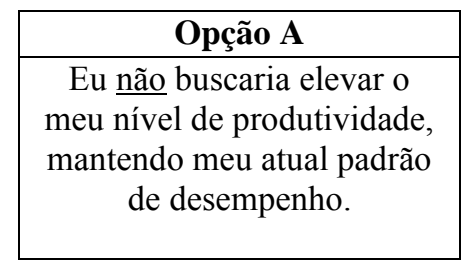

\begin{tabular}{|c|}
\hline Opção B \\
\hline Eu buscaria elevar o meu \\
nível de produtividade, \\
tendo em vista a \\
melhoria do desempenho \\
da equipe. \\
\hline
\end{tabular}

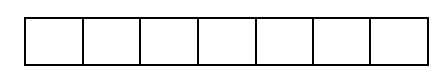


9. As atividades que foram delegadas a sua equipe foram concluídas com êxito. Entretanto, uma outra equipe de trabalho próxima a sua lhe solicita auxílio para a finalização das tarefas. Diante da possibilidade de contribuição, o que você faria?

\begin{tabular}{|c|}
\hline Opção A \\
\hline $\begin{array}{c}\text { Eu não ajudaria a outra } \\
\text { equipe a finalizar suas } \\
\text { atividades. }\end{array}$ \\
\hline
\end{tabular}

\begin{tabular}{|c|}
\hline Opção B \\
\hline Eu ajudaria a outra \\
equipe a finalizar suas \\
atividades. \\
\hline
\end{tabular}

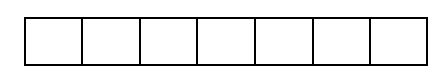

10. A organização na qual você trabalha está com o quadro de pessoal reduzido, requerendo de você a realização de mais tarefas do que as exigidas para o seu cargo, tendo em vista a necessidade de atingimento das metas organizacionais. Diante da solicitação e sabendo que você possui o conhecimento necessário para realizar essas novas atividades, o que você faria?

\begin{tabular}{|c|}
\hline Opção A \\
\hline Eu não assumiria essas \\
novas tarefas. \\
\hline
\end{tabular}

\begin{tabular}{|c|}
\hline $\begin{array}{c}\text { Eu assumiria essas novas } \\
\text { tarefas. }\end{array}$ \\
\hline
\end{tabular}

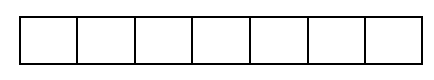

11. Suponha que sua organização lhe solicitou que se engaje em atividades para melhorar a forma como a organização é vista pela sociedade. Qual decisão você tomaria?

\begin{tabular}{|c|}
\hline Opção A \\
\hline $\begin{array}{c}\text { Eu tomaria alguma iniciativa } \\
\text { no sentido de promover tal } \\
\text { melhoria. }\end{array}$ \\
\hline
\end{tabular}

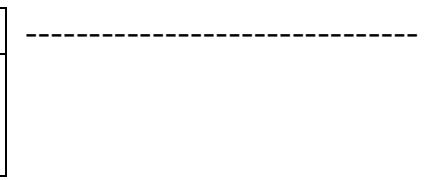

\begin{tabular}{|c|}
\hline Opção B \\
\hline Eu não tomaria qualquer \\
iniciativa no sentido de \\
promover tal melhoria. \\
\hline
\end{tabular}

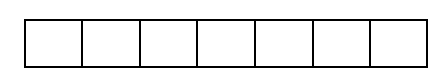

12. Em uma conversa descontraída com seus colegas de trabalho, um deles questiona e critica injustamente a empresa onde você trabalha. Que posição você assumiria?

\begin{tabular}{|c|}
\hline Opção A \\
\hline $\begin{array}{c}\text { Eu defenderia a organização } \\
\text { das críticas dos colegas. }\end{array}$ \\
\hline
\end{tabular}

\begin{tabular}{|c|}
\hline Opção B \\
\hline Eu não defenderia a \\
organização das críticas \\
dos colegas. \\
\hline
\end{tabular}

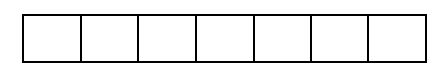

13. A organização na qual você trabalha adota um modelo de gestão participativa para que seus funcionários possam se envolver no processo de elaboração de novos projetos a partir do próximo ano. Diante da possibilidade de participação, o que você faria?

\begin{tabular}{|c|}
\hline Opção A \\
\hline Eu não me ofereceria para \\
participar desses novos \\
projetos.
\end{tabular}

\begin{tabular}{|c|}
\hline Opção B \\
\hline Eu me ofereceria para \\
participar desses novos \\
projetos. \\
\hline
\end{tabular}

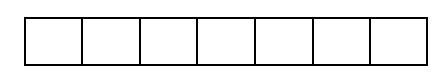


14. A organização redefiniu as metas de desempenho para o próximo ano e isso exigirá de você uma carga de trabalho adicional. Que posição você assumiria?

\begin{tabular}{|c|}
\hline Opção A \\
\hline $\begin{array}{c}\text { Eu mudaria minha forma de } \\
\text { trabalhar para me adequar às } \\
\text { novas metas. }\end{array}$ \\
\hline
\end{tabular}

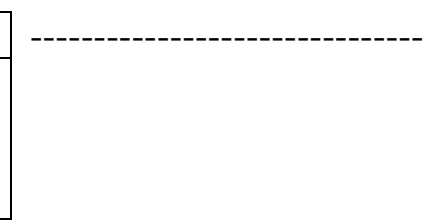

\begin{tabular}{|c|}
\hline Opção B \\
\hline Eu não mudaria minha \\
forma de trabalhar, não \\
me adequando às novas \\
metas. \\
\hline
\end{tabular}

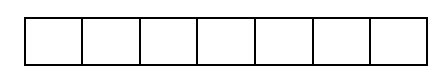

15. A organização está implantando programas de melhoria do seu desempenho e da qualidade de seus serviços. Este programa exige mudanças na sua forma de trabalhar e a necessidade de uma nova adaptação ao seu trabalho. O que você faria?

\begin{tabular}{|c|}
\hline Opção A \\
\hline $\begin{array}{c}\text { Eu não me engajaria no } \\
\text { programa. }\end{array}$ \\
\hline
\end{tabular}

\begin{tabular}{|c|}
\hline Opção B \\
\hline $\begin{array}{c}\text { Eu me engajaria no } \\
\text { programa. }\end{array}$ \\
\hline
\end{tabular}

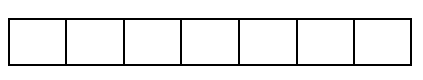

16. Imagine que sua organização implantou um sistema de críticas e sugestões acessível a todos os funcionários. Que posição você assumiria?

\begin{tabular}{|c|}
\hline Opção A \\
\hline Caso tivesse críticas e \\
sugestões, eu as apresentaria \\
à organização.
\end{tabular}

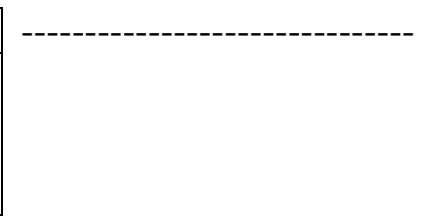

\begin{tabular}{|c|}
\hline Opção B \\
\hline Mesmo tendo críticas e \\
sugestões, eu as \\
guardaria para mim \\
mesmo. \\
\hline
\end{tabular}

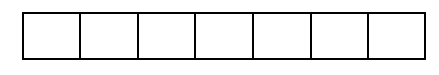

17. Um dos clientes da organização na qual você trabalha dirige críticas ao atendimento prestado pelo órgão e insinua que outros órgãos possuem uma qualidade de atendimento superior. Qual posição você assumiria?

\begin{tabular}{|c|}
\hline Opção A \\
\hline $\begin{array}{c}\text { Eu não defenderia a } \\
\text { organização das críticas do } \\
\text { cliente. }\end{array}$ \\
\hline
\end{tabular}

\begin{tabular}{|c|}
\hline Opção B \\
\hline Eu defenderia a \\
organização das críticas \\
do cliente. \\
\hline
\end{tabular}

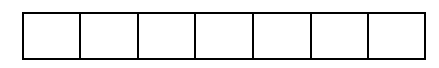

18. A organização onde você trabalha está sendo reestruturada, o que implica em redimensionamento de setores e remanejamento de pessoal. Estas mudanças são vistas pela organização como necessárias para a melhoria de seu desempenho. Que posição você assumiria diante destas mudanças?

\begin{tabular}{|c|}
\hline Opção A \\
\hline $\begin{array}{c}\text { Eu faria o possível para não } \\
\text { mudar de setor. }\end{array}$ \\
\hline
\end{tabular}

\begin{tabular}{|c|}
\hline Opção B \\
\hline $\begin{array}{c}\text { Eu mudaria de setor, } \\
\text { caso fosse necessário. }\end{array}$ \\
\hline
\end{tabular}

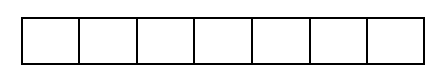


19. Dificuldades financeiras levam a sua organização a restringir benefícios e vantagens que vinha oferecendo aos colaboradores. Que posição você assumiria?

\begin{tabular}{|c|}
\hline Opção A \\
\hline Se possível, eu tomaria \\
alguma iniciativa no sentido \\
de evitar tais restrições. \\
\hline
\end{tabular}

\begin{tabular}{|c|}
\hline Opção B \\
\hline Mesmo que possível, eu \\
não tomaria qualquer \\
tipo de iniciativa, \\
aceitando as restrições. \\
\hline
\end{tabular}

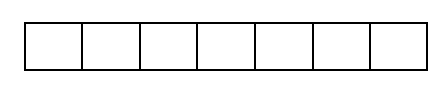

20. A organização está enfrentando um problema cujo encaminhamento está confiado a um outro setor de trabalho que não é o seu. Você possui alguma ideia de como resolvê-lo. O que você faria?

\begin{tabular}{|c|}
\hline Opção A \\
\hline $\begin{array}{c}\text { Eu me ofereceria para } \\
\text { ajudar. }\end{array}$ \\
\hline
\end{tabular}

\begin{tabular}{|c|}
\hline Opção B \\
\hline Eu não me ofereceria \\
para ajudar. \\
\hline
\end{tabular}

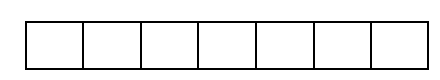

Fonte: Adaptado de Menezes (2006); Menezes e Bastos (2010).

PARTE II:

A seguir você deve avaliar cada uma das afirmativas seguintes na coluna à direita, de acordo com a escala abaixo, indicando o quanto você concorda ou discorda de cada uma delas, escolhendo o número (de 1 a 5) que melhor reflete a sua percepção em relação às políticas de gestão de pessoas do Ministério do Meio Ambiente. Por favor, não deixe nenhum item em branco!

\begin{tabular}{|c|c|c|c|c|}
\hline $\mathbf{1}$ & $\mathbf{2}$ & $\mathbf{3}$ & $\mathbf{4}$ & $\mathbf{5}$ \\
\hline $\begin{array}{c}\text { Discordo } \\
\text { totalmente da } \\
\text { afirmativa }\end{array}$ & $\begin{array}{c}\text { Discordo } \\
\text { parcialmente da } \\
\text { afirmativa }\end{array}$ & $\begin{array}{c}\text { Não concordo nem } \\
\text { discordo da } \\
\text { afirmativa/Não se } \\
\text { aplica }\end{array}$ & $\begin{array}{c}\text { Concordo } \\
\text { parcialmente com a } \\
\text { afirmativa }\end{array}$ & $\begin{array}{c}\text { Concordo } \\
\text { totalmente com a } \\
\text { afirmativa }\end{array}$ \\
\hline
\end{tabular}

Registre, no espaço disponível, o número que corresponde à sua posição frente ao item:

\begin{tabular}{|c|c|c|c|c|c|}
\hline & 1 & 2 & 3 & 4 & 5 \\
\hline \multicolumn{6}{|l|}{$\begin{array}{l}\text { 1. Os processos de recrutamento (externo e interno) de candidatos a } \\
\text { ocuparem vagas na organização onde eu trabalho são amplamente } \\
\text { divulgados. }\end{array}$} \\
\hline \multicolumn{6}{|l|}{$\begin{array}{l}\text { 2. Os processos seletivos da organização onde eu trabalho são disputados, } \\
\text { atraindo pessoas competentes. }\end{array}$} \\
\hline \multicolumn{6}{|l|}{$\begin{array}{l}\text { 3. Os testes de seleção da organização onde eu trabalho são conduzidos por } \\
\text { pessoas capacitadas e imparciais. }\end{array}$} \\
\hline \multicolumn{6}{|l|}{$\begin{array}{l}\text { 4. A organização onde eu trabalho utiliza-se de vários instrumentos de } \\
\text { seleção (ex: entrevistas, provas, etc.). }\end{array}$} \\
\hline \multicolumn{6}{|l|}{$\begin{array}{l}\text { 5. A organização onde eu trabalho divulga aos candidatos informações a } \\
\text { respeito das etapas e critérios do processo seletivo. }\end{array}$} \\
\hline \multicolumn{6}{|l|}{$\begin{array}{l}\text { 6. A organização onde eu trabalho comunica aos candidatos seu desempenho } \\
\text { ao final do processo seletivo. }\end{array}$} \\
\hline \multicolumn{6}{|l|}{ 7. A organização onde eu trabalho se preocupa com meu bem-estar. } \\
\hline \multicolumn{6}{|l|}{ 8. A organização onde eu trabalho me trata com respeito e atenção. } \\
\hline \multicolumn{6}{|l|}{$\begin{array}{l}\text { 9. A organização onde eu trabalho procura conhecer minhas necessidades e } \\
\text { expectativas profissionais. }\end{array}$} \\
\hline \multicolumn{6}{|l|}{$\begin{array}{l}\text { 10. A organização onde eu trabalho estimula a minha participação nas } \\
\text { tomadas de decisão e resolução de problemas. }\end{array}$} \\
\hline $\begin{array}{l}\text { 11. A organização onde eu trabalho reconhece o trabalho que faço e os } \\
\text { resultados que apresento (ex: elogios, matérias em jornais internos, etc.). }\end{array}$ & & & & & \\
\hline
\end{tabular}




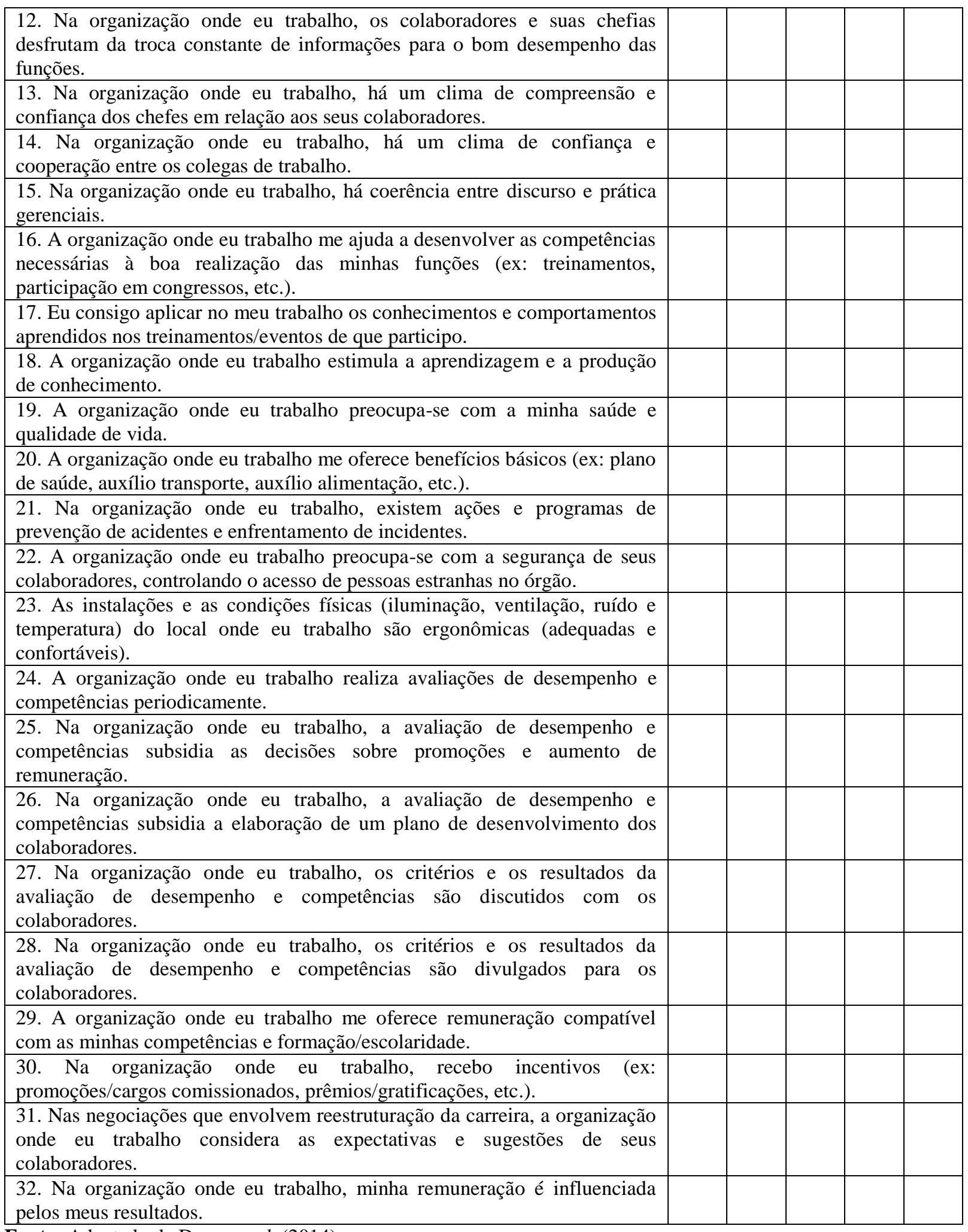

Fonte: Adaptado de Demo et al. (2014). 


\section{PARTE III - DADOS PESSOAIS E PROFISSIONAIS:}

1) Qual o seu sexo?

1. Feminino

2. Masculino

2) Qual sua faixa de idade?

1. De 18 a 20 anos

2. De 21 a 30 anos

3. De 31 a 40 anos

4. De 41 a 50 anos

5. De 51 a 60 anos

6. Acima de 60 anos

3) Qual a sua escolaridade?

01. Não alfabetizado

02. Ensino fundamental incompleto

03. Ensino fundamental completo

04. Ensino médio incompleto

05. Ensino médio completo

06. Superior incompleto

07. Superior completo

08. Pós-graduação lato sensu (Especialização/MBA)

09. Mestrado

10. Doutorado ou Pós-Doutorado

4) Qual carreira você faz parte?

1. Carreira de Especialista em Meio Ambiente - CEMA (Ex: Analista Ambiental)

2. Plano Especial de Cargos do Meio Ambiente e do IBAMA - PECMA (Ex: Agente Administrativo)

3. Especialista em Políticas Públicas e Gestão Governamental - EPPGG

4. Carreira de Analista de Infraestrutura - CAINFRA

5. Carreira de Analista de Planejamento e Orçamento - APO

6. Outra. Especifique:

5) Quanto tempo você trabalha no Ministério do Meio Ambiente - MMA?

1. Menos de 1 ano

2. De 1 a 3 anos

3. De 4 a 8 anos

4. De 9 a 13 anos

5. De 14 a 19 anos

6. De 20 a 30 anos

7. Acima de 30 anos

\section{6) Qual a sua unidade de lotação?}

Gabinete da Ministra - GM

Assessoria Parlamentar - ASPAR

Assessoria de Comunicação Social - ASCOM

Assessoria de Assuntos Internacionais - ASIN

Consultoria Jurídica - CONJUR

Secretaria Executiva - SECEX

Subsecretaria de Planejamento, Orçamento e Administração - SPOA/SECEX

Secretaria de Mudanças Climáticas e Qualidade Ambiental - SMCQ

Secretaria de Biodiversidade e Florestas - SBF

Secretaria de Recursos Hídricos e Ambiente Urbano - SRHU 
Secretaria de Extrativismo e Desenvolvimento Rural Sustentável - SEDR

Secretaria de Articulação Institucional e Cidadania Ambiental - SAIC

Serviço Florestal Brasileiro - SFB

7) Você participa ou já participou de algum programa de incentivo educacional do MMA?

1. Sim. Programa de Incentivo à Graduação - PROGRAD

Programa de Incentivo à Pós-Graduação

Programa de Incentivo ao Estudo de Língua Estrangeira - PROLÍNGUE

2. Não.

8) Você ocupa cargo em comissão ou função gratificada no MMA?

1. Sim. Qual? Natureza Especial - NE

DAS 101.6

DAS 101.5

DAS 101.4

DAS 101.3

DAS 101.2

DAS 101.1

DAS 102.5

DAS 102.4

DAS 102.3

DAS 102.2

DAS 102.1

FG-1

FG-2

GSISTE

GSISP

2. Não. 